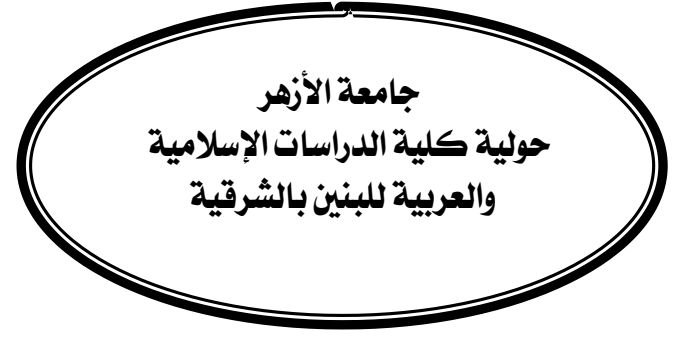

\title{
الاقمتباس التمرآني
}
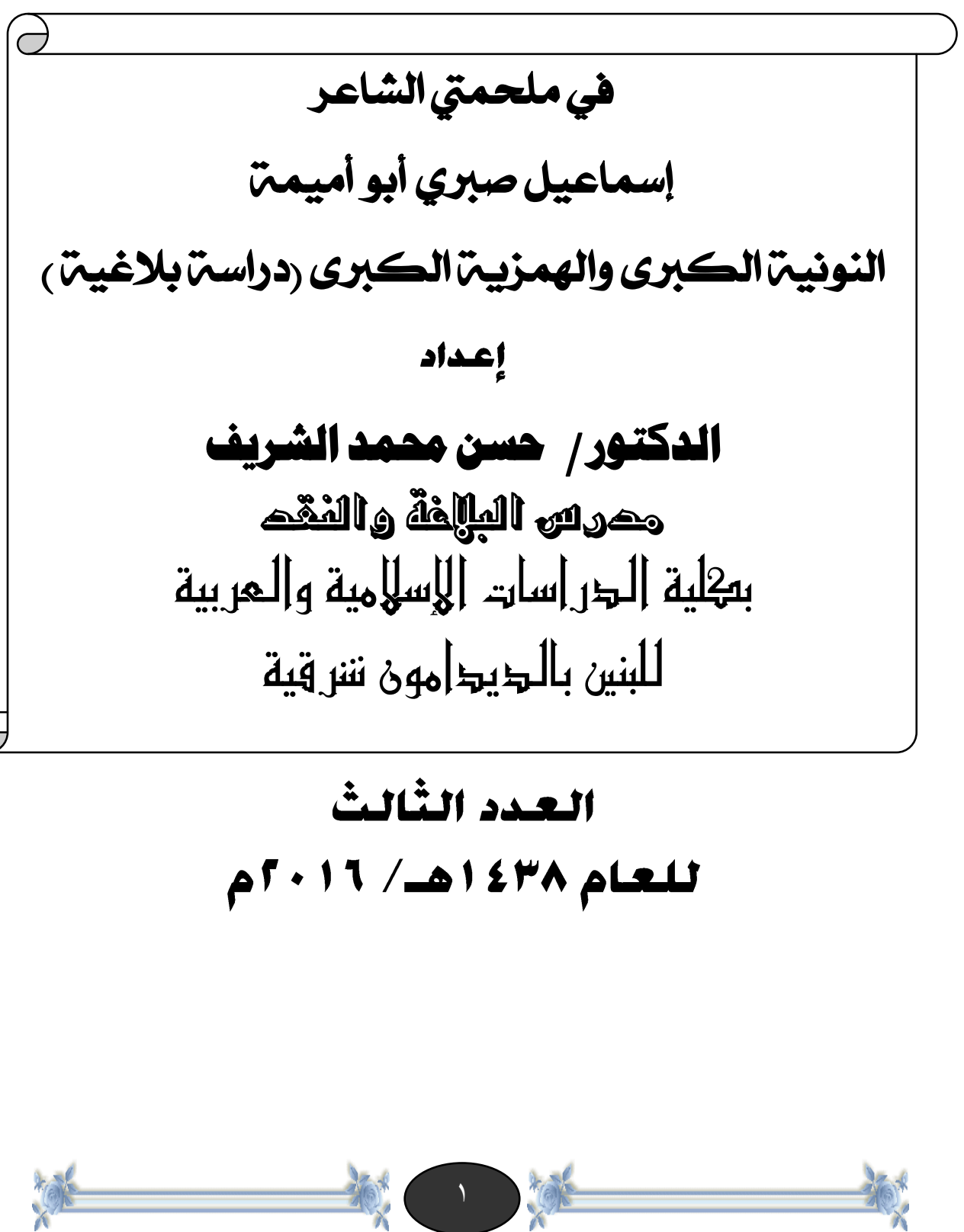


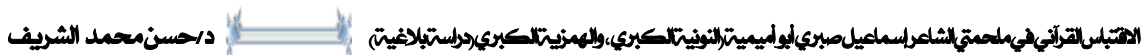
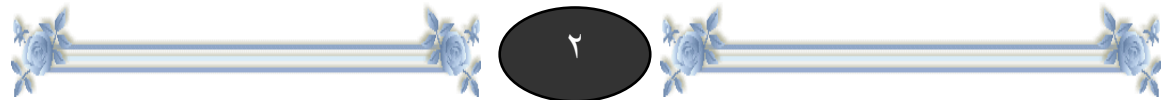


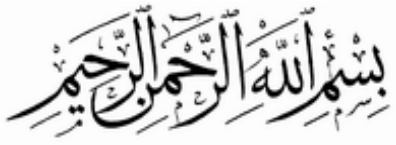 \\ |لمقحهــ}

الحمد لله والصلاة والسلام علي خير خلق الله سيدنا محمد وعلي آله وصحبه ، وارض اللهم عن سـادتنا آل بيت رسول الله ـ صـي الله عليه

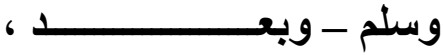

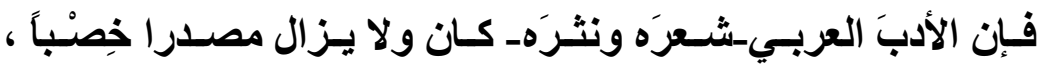
ومعينا لا ينضب ، ومنهلا عذبا للار اسة والبحث .

وباطلاعي على ديوان الثـاعر إسماعيل صبري أبو أميمـة وجدتُه جديرا بالعناية و الاهتمام : فهو شاعر فصيحّ مجيدٌ يمتلك موهبة فذة و ذكـاء وقَّاداً ، وحافظة واعيـة ، واطلاعـا واسـعا ، وإلمامـا بـدقائق اللغـة

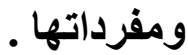

و فوق ذلك كله فهو شاعر أصيلُ الطبع يتمتع بعاطفة دينية أصيلة، بـدت واضحة جليـة في ملحمتيه النونيـة الكبرى والتي بلـغ عدد أبياتها تسعمائة وأربعة وخمسين بيتا ، و الهمزية الكبرى والتي بلغ عدد أبياتها خمسمائة وتسعة وستين بيتا ـ استعرض الشاعر فيهما أحوال البشرية وتاريخها وأخبار ها. والملحمت الأولى النونيت الكبرى من بحر الخفيف مطلعها: 


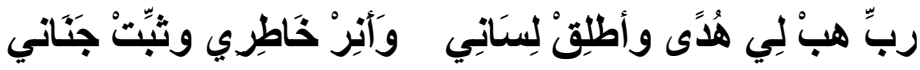

بدأها الشاعر بنظم أسماء الله الحسنى،ثم تحدث عن البعث والنشور و القيامـة وأهوالهـا، ومـا ينتظر الإنسـان مـن جنـة أو نـار، ثم تحدث عن مخلوقات الله المتنوعة ، ومنها تطرق إلى الإسلام وتاريخه.

وسـار على النهج نفسـه في ملحمته الثانيـة الهمزيـة الكبرى وهى

كذلك من بحر الخفيف . اك.

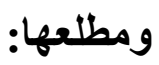

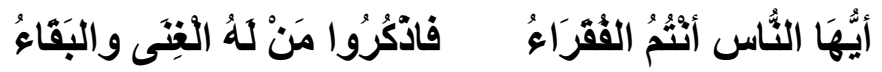

ولعل أهـم مـا يميـز هـاتين الملحمتـين الصـبغة الاينيـة والعاطفـة

الإسلامية الجيَّاشة والتي تمتع بها شاعرُنا ، والمتمثَّة في كثرة تضمينه

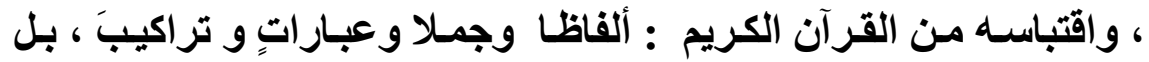
وآياتٍ جعلت لشعره طابعا إسـلاميا ، وكثفت عن تمكنه من ثراثـه الديني والأدبي ، و مهارتِه في إحكام الصلة ، و براعتِه في توظيفِِ و دمـج بيـان

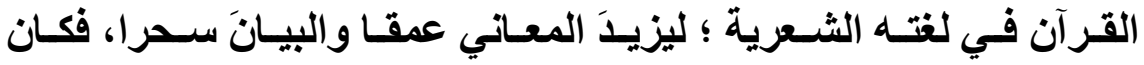
موضوع هذا البحث : (الاقتبـاس القرآنسي في ملحمتي الثـاعر إسـماعيل صبري أبو أميمة : النونية الكبرى ، و الهمزية الكبرى دراسة بلاغية ) وقد اقتضت خطة الاراسة أن تكون في أربعة مباحث يسبقها تمهيد تناولت فيـه التعريـف بالثـاعر إسـماعيل صسبري أبـو أميمسة ونبـة عن 
وجعلت المبحث الأول: مقام تمجيد الله - جلّ وعلا- والثناء عليه ،

والمبحث الثاني : مقام التذكير ببعض مظاهر قرة الله تعالى ،

والمبحث الثالث : النصح و الإرشاد ،

والمبحث الرابع مقام أهوال يوم القيامة ،

• مر خاتمت وثبت للمراجع

وبعد

فالثكر موصول لكل من قدم لـي المسـاعدة في إنجاز هذا البحث

المتواضع راجيا من الله ـ تعالى ـ أن يحقق الههف المنشود منه ، وحسبي

أنني حاولت واجتهرت ، والكمال لله وحده ،

واللهَ اسأل أن يجعل هذا العمل خالصا لوجهـه الكريم ، إنَّهـه ولـي ذلك

والقادر عليه .

ربنا لا تؤاخذنا إن نسينا أو أخطانا ، والحمد لله أولاو آخرا ،؛،

د حسن الشريف 


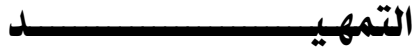

أولا : التعريف بالشاعر إسماعيل صبري أبو أميمتة : (').

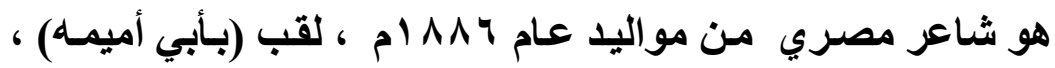
وعرفف أيضًا باسم 》إسماعيل صبري الصغير) أو(إسماعيل صبري أفندي) للتمييز بينه وبين معاصره الثاعر 》إسماعيل صبري باشای)

لم تمكنه ظروفه من إتمام تعليمه العالي ، فاكتفى بالمرحلة الثانويـة ، عمل بالتعليم لسنوات طوال إلى أن كف بصره فترك الخدمة آسفا ، و

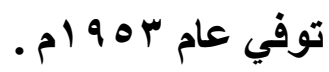

و شـاعرنا فنـان وهبتهـ الطبيعـةُ حظاً كبيراً مـن المقدرة القنيـة في ضروب عديدةٍ : فهو يحسنُ الخط العربي إلى درجة الإتقان ، كما كان يجيد فن الرسم إلى مرتبةٍ جعتله يختص بتدريس مادة الرسم في مدارس الوزارة ، وفوق ذلك فهو شاعر قوى الديباجة ، سليم اللغة ، جياشا بنوازع النفس ، حتى إن شعره ليختار منه المقطوعات المناسبة يلحنها الملحنون ويغنيها المغتون من أبناء جيله فيكسبونها بأصواتهم نغما يصل إلى القلوب ويشنف

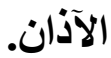

وقد كان هذا هو الباب الذي نفذ منه الشاعر إلى مجتمعه .

ألف روايات كثيرة تعالج مشاكل المجتمع كـروايتي : ( الشبح ، وبدر البدور) وغيرهـا ،كمـا قام بترجمـة بعض الروايـات الأجنبيـة وهيأهـا

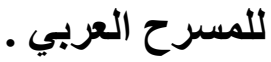

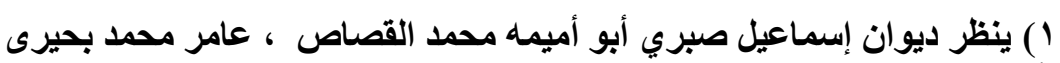

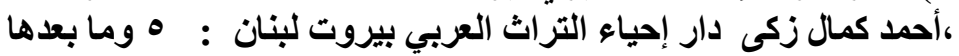


يتمتع الثاعر بنفس طيبة كريمة وروح مرحة منبسطة ، يسلم أمره

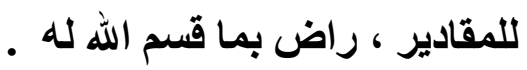

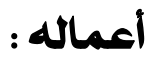

كتب 》إسـماعيل صبري) مجموعـة كبيرة مـن الأثـعار ،كمـا كتب

مجموعة من المسرحيات الشعبية ، صدر له ديوان شعر عنيت بنشره إدارة إحياء التراث التابعـة لـوزارة الثقافـة المصرية، وعهدت إلى ثلاثتة مـن

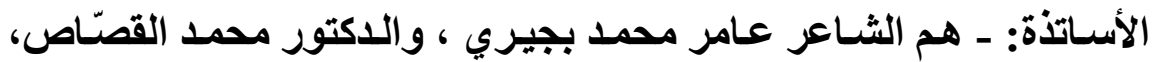
والدكتور أحمد كمال زكي - بجمع تراث هذا الثـاعر المغمور، ثم أخرجته في ديوان كبير بتقديم وافٍ، كتبه الثاعر عامر بجيري رحم الله الثاعر رحمة واسعة وأسكنه فسيح جناته ،،، ثانيا : الاقتباس و أقسامه وحكمه وموقعه البلاغي :

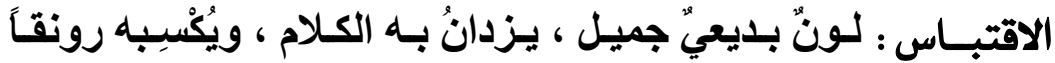
وجمالًا ؛ ذلك لكونه وثيقَ الصلةِ بالقرآن الكريم ويالحديثِ النبوي الثريف

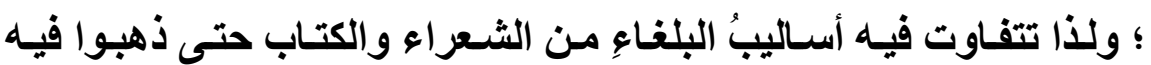
مذاهبَ شتى من التفنن والإبداع ، كاشفين عن مهاراتهم في إحكام الصلة بين كلامهم وما اقتبسوه ، حتى غدا فناً جميلاً ، وأسلوياً عالياً وعادةً متبعة التهنة

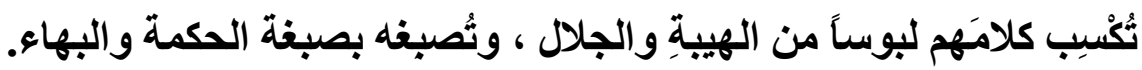


وهو كغيره من الألوان البايعية لا يقصد به تحسين الكلام فحسب ، و

إنما هو فٌْ وثيقُ الصلة ببلاغة الكلام ، يقوي به المتكلم كلامه، ويُحْكِمُ به نظامه، وفاء بالمعنى واستجابة لمقتضى الأحوال .

وأصله طلب القبس وهو الثـعلة من النـار يقـال : قبس واقتبس ،

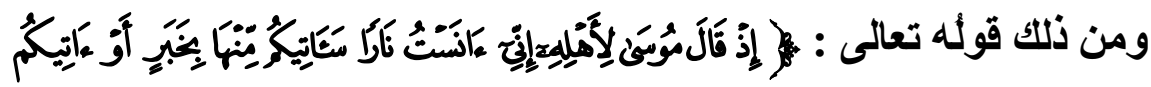

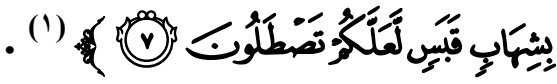

(أي آتيكم بثعلة نار مقبوسة أي مأخوذة من أصلها ) () .

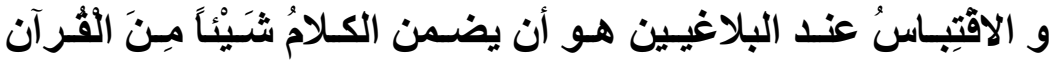

$$
\text { الكريم أو الحديثِ الشريفِ لا على أنه منه )(") . }
$$

كما يطلق على استفادة العلم و الهداية على سبيل الاستعارة ومنـه

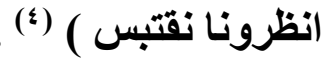

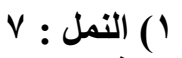

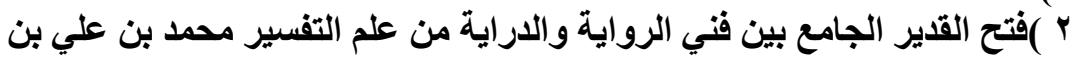

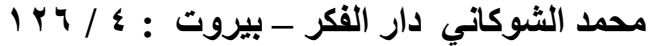

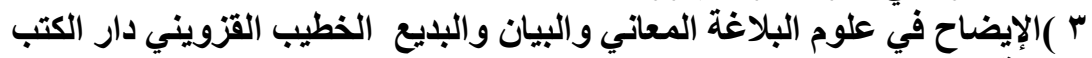

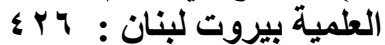

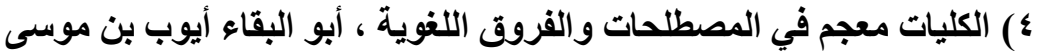

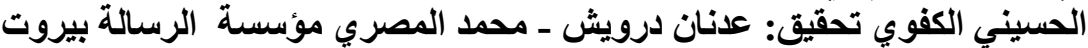

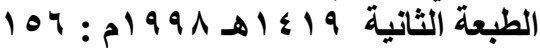

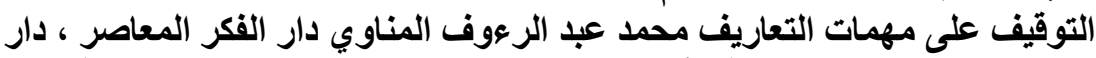

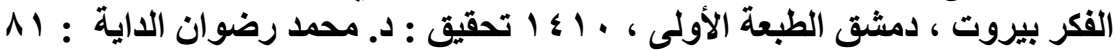

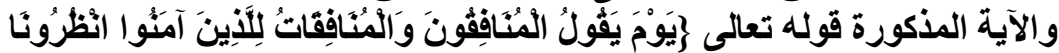

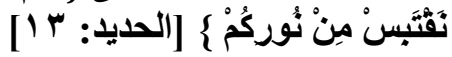


( وسمى الإتيان بالقرآن أو الحديث على الوجه المذكور اقتباسـا أخذا من اقتباس نور الصباح من نور القبس وهو الثهاب؛ لأن القرآن والحديث أصل الأنوار العلمية )(') - (')

فالمتكلم يأخذ من القرآن الكريم أو الحديث الشريف في كلامسه مـا هو بمنزلة جذوة نار يستضيء به على أن لا يكون في كلامـه مـا يشعر بكون المقتبَس من القرآن أو الحديث الثريف ، كأن يقول : قال الله كذا ، أو قال رسول الله ـ صلى الله عليه وسـلم ـ كذا ، ولهذا يحسن أن يمهد للمقتبَس بحيث يكون مندمِجا في الكلام اندماجا تاما ، حتى يصير من كلام المقتبس نفسل (r) (ن)

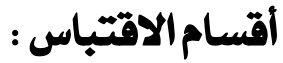

قسم البلاغيون الاقتباس من حيث نقل المقتبس عن معنـاه الأصلي وعدم نقله إلى قسمين :

الأول : ما لم ينقل فيه اللفظ المقتبس عن معنـاه الأصلي إلى معنى آخر وذلك كقول الحريري : (فلم يكنْ إلا كلمـح البصر، أو هو أقربُ،حتى

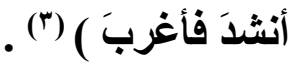
والثاني: ما نقل فيه المقتبس عن معناه الأصلي

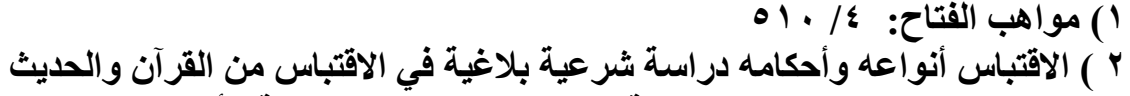

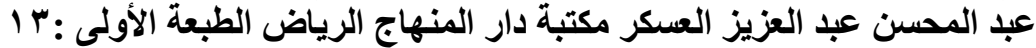

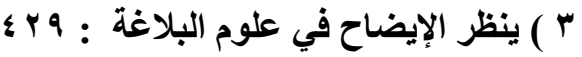




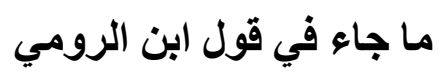

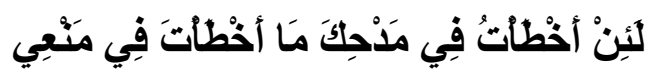

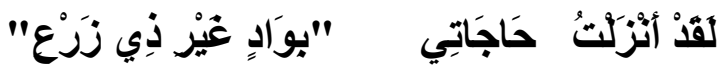

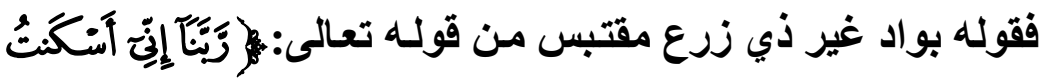

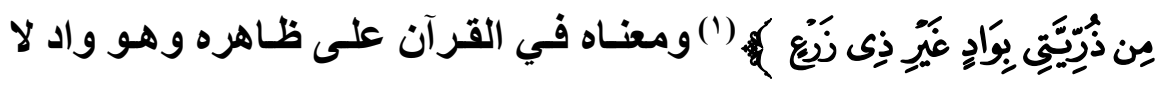

ماء فيه ولا نبات وهو شعب مكة المشرفة ، وقد نقله الثشاعر إلى جناب لا

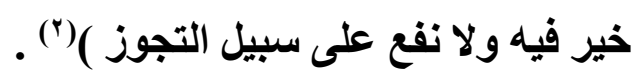

هذا وقد أورد الإمام السيوطي أن الاقتباس ينقسم باعتبار قبولـه من عدمه إلى ثلاثة أقسام مقبول ومباح ومردود : فالأول : ما كان في الخطب والمواعظو العهود ـ. والثاني : ما كان في القول والرسائل والقصص .

والثالث : على ضربين أحدهما مـا نسبه الله إلى نفسـه ونعوذ بالله ممن ينقله إلى نفسه كما قيل عن أحل بني مروان أنه وقع على مطالعة فيها 


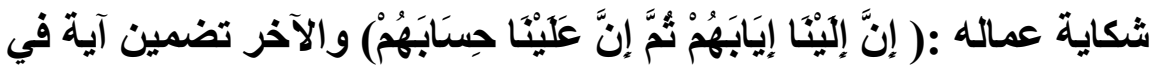

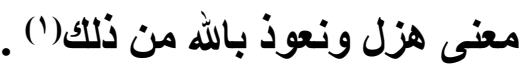

هذا والتغيير اليسير في اللفظ المقتبس لا يخرجه عن كونـه اقتباسـا كما في قول بعض المغاربة عند وفاة بعض أصحابه :

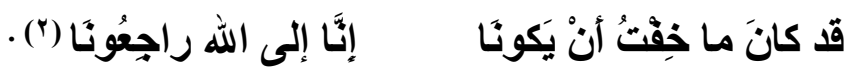
هذا وقد اشتقّ البلاغيّون من الاقتباس أربعة فروع وهي: التضمين و العَعَدِ و الحَلّْه و التلميح.

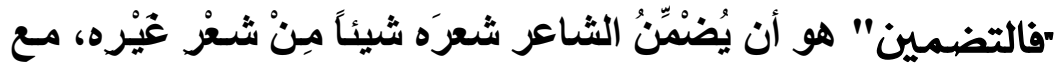

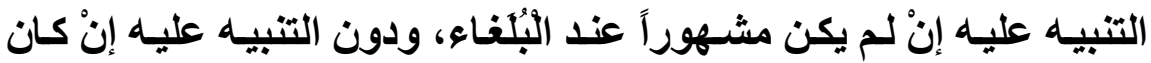
مشهوراً.

"والعَقد": هو أن ينظم الثاعر نثراً لغيره لا على طريقة الاقتباس.

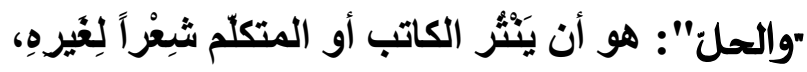
"والثلميح": هو أن يُشِيرُ الناثر أو الثشاعر إلى قصة أو شعْر أو نثر

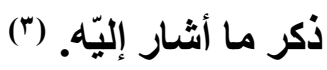

() الإتقان في علوم القرآن جلال الدين عبد الرحمن السيوطي تحقيق سعيد المندوب

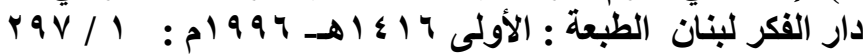

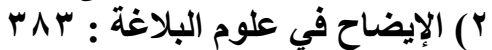

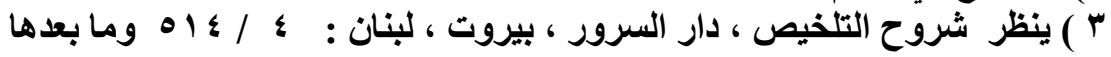




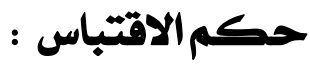

أما حكم الاقتباس من الناحية الشرعية فالذي عليه جمهور العلمـاء من الحنفية والمالكيـة والحنابلة والثـافعية جواز الاقتباس من القرآن في النثر ومجيء الاقتبـاس القرآني في السنة النبويـة دليل على إباحته فقد روى البخاري ومسلم في صحيحيهما أن رسول اللهـ صلى الله عليه وسـلم-

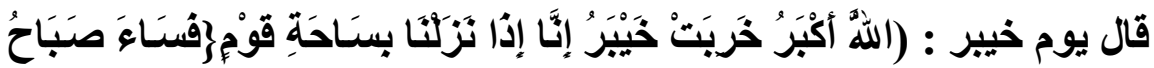

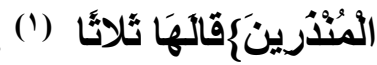

ومما استلال به على الجواز أيضا ثبوت الاقتباس بالأسانيا الصحيحة عن كبار الصحابة كاببي بكر وعثمان وعلى وابن مسعود ومعاذ بن جبل رضـي الله عنهم أجمعين وثثبوتـه كذلك عن التـابعين ومـن بعدهم الأئمـة الأعلام ومشاهير الإسلام كالإمام مالك و والثافعي وأبى حامد الغزالـي وابن تيمية وابن القيم فإنهم قد اقتبسوا من القرآن ولم يروا به بأسـا ولـم ينكروه وإذا جاز الاقتباس من القرآن في النثر فمن الحديث التبوي من بـاب أولى أما الاقتباس في الشعر : فالأي عليه أكثر العلماء الجواز ) () .

(1) صحيح البخاري الجامع المسند الصحيح المختصر من أمور رسول الله صلى الله الهي

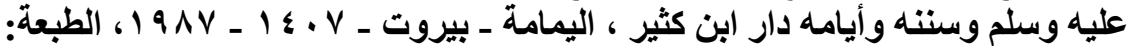

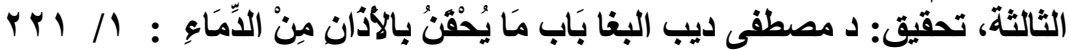

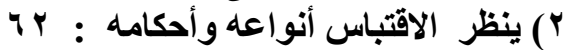




\section{البحث الأول}

تمجيا الله - جلّ وعلا- والثناء عليه :

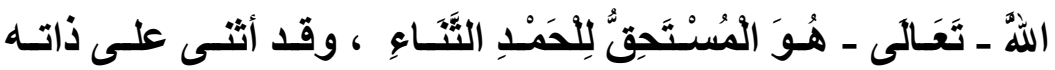
المقدسة بما هو أهله مِنْ خِصَّال الجـلال والعظمـة والكبريـاء ، وعلم عبـاده كيف يثنون عليه ، ويحمدونها ، وقد سـار الثـاعر على نهج القرآن الكريم في الثناء على الأت العلية ، متأثرا بلغته ومقتبسا منـه فقد استهل نونيته ('): الكبرى بقوله

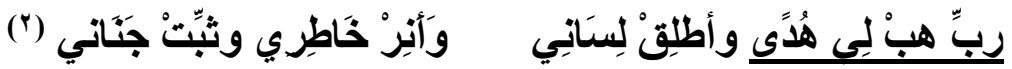

فالثـاعر يضرع إلى ربـه طالبـا الهدايةة ، وطلاقة اللسـان ، وإنـارة الخـاطر ، وتثبيت الجنـان ، وهى دعوات مناسبة لمقـام البدء والاستهلال

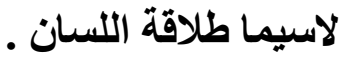

وشاعرنا متأثر بالقرآن وبلغته يستحضر من كلماته وجمله وأسـاليبه مـا يناسـب موقفهـ ، وقـد أفـاض على دعواتـه مسن قدسية القرآن وجـلال

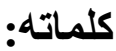

( ) ديوان إسماعيل صبري أبو أميمه:

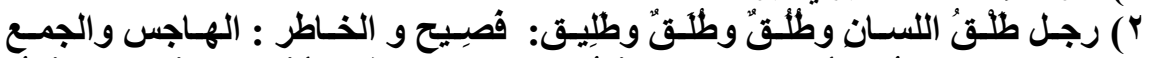

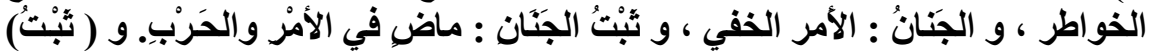

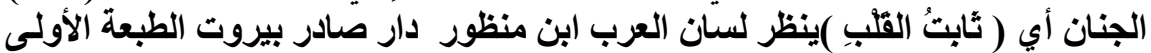

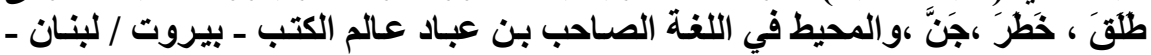

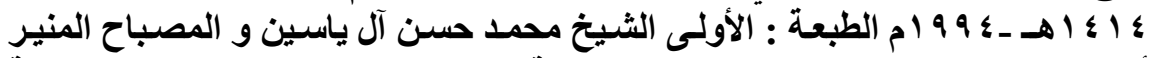

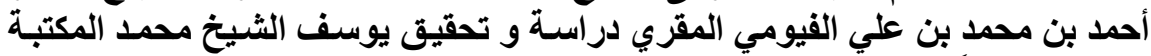

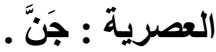


فقولهه : (ربِّ هبْ لِي هُدَى) مقتبس من دعوة الخليل إبراهيم - عليه

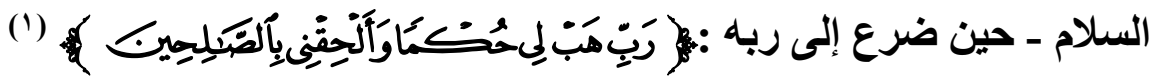

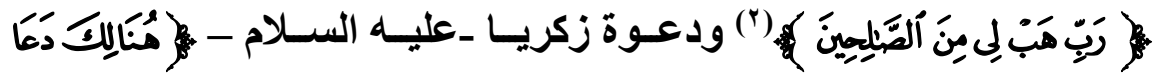

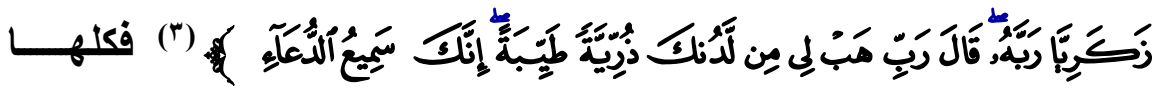
دعوات قرآنية آثرت التضرع بلفظ : (رب)لأنه ـ تعالى- مربيه ومصلح حالـه ، وجـاء الطلب بلفظ :( هب) لأن الهبـة إحسـان محض ليس في مقابلتها شيع يكون عوضاً للواهب ) (") وقد تأثر بها الشـاعر واستحضرها صورة ماثـلة أمسام عينـهـ ؛ ولأن شَاعرنا تواقا إلى الههاية يرجوها ويتمناها نكر (هُدَى ) لإرادة التعظيم، ثم جـاء قولـه :(وأطلِقْ لِستَانِي) كنايـة عن البيان وفصساحة اللسـان ، فأطلق اللسان وأراد القدرة على البيان الفصيح على سبيل المجـاز المرسل لعلاقة الآلية وقوله:( وأطلِق لِسنانِي) مقتبس من دعوة كليم الله موسى -

$$
\begin{aligned}
& \text { () الثعراء: }
\end{aligned}
$$

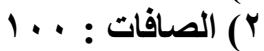

$$
\begin{aligned}
& \text { r }
\end{aligned}
$$

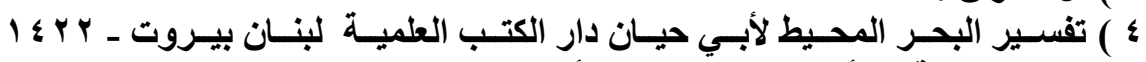

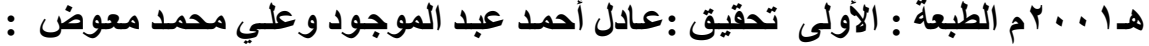




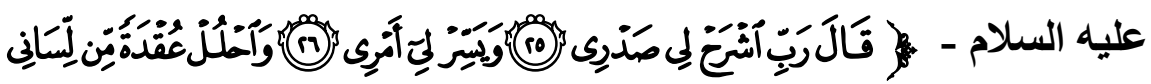

ثم يختم شـاعرنا ضر اعته إلى ربها بطلب الثبات والتأييد مكنيا عن

ذلك بإنارة الخاطر وثبات الجنان ،

ويمضى شاعرنا في ثنائه على الله تعالى فيقول :

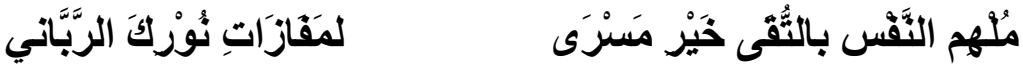

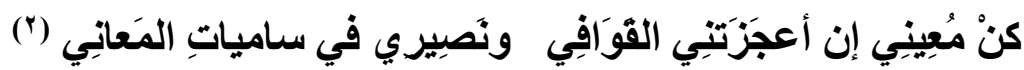

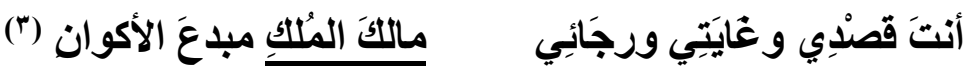

وكمها حذف أداة النداء في قولهه : (ربِّ هبْ لِي هُدَى) حذف هنـا :

( مُلهم النَّفس) ليكثف عن مدى إحساسه بالقرب من خالقه ومقدار لهفته

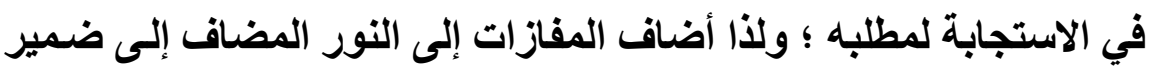

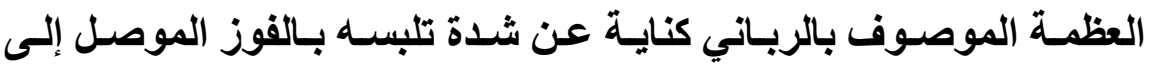
النجاة ، ولحرصـه على دوام العون من الله ـتعالى-جـاء الوصف (مُعِينِي)

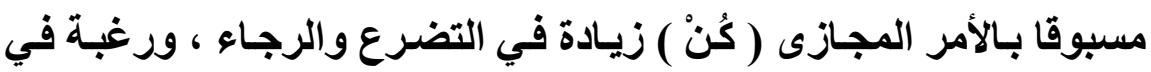
سرعة تحقيق المعونة المرجوة ، وفى إثارة إلى مقدرته الشعرية وتوفيقه

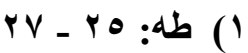

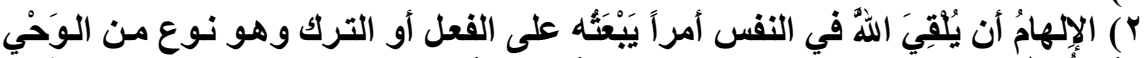

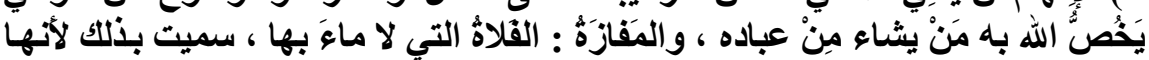

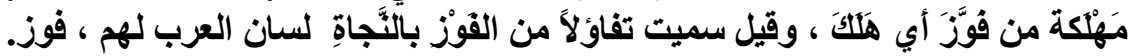

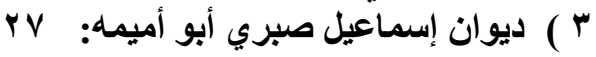


الــائم وتمكنـه مـن قرض الشـعر ونـدرة تعجيز القوافي إيـاه ، جـاء بـأداة الشرط :(إن)(الدالة على عدم تحقق الشرط|'( )

وإسـناد العجز للقوافي هو إسـناد مجـازى لعلاقـة السببية إظهـاراً لأهمية القوافي وبيان مدى تأثثيرها ؛ كما أن إطلاق القوافي هنـا جاء على سـبيل المجـاز المرسـل لعلاقـة الجزئيـة إذ القافيـة أشـرف أجـزاء البيـــ

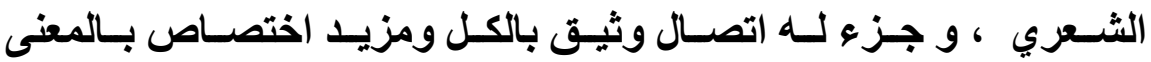
والسياق، ثم يتوجه إلى ربـه بالخطاب : (أنـتَ قصندِي وغَايَتِي ورجَائي) متضر عا إليه_تعالى - بما هو أهله ، من قرة تامـة وسلطان نافذ ، ورحمـة واسعة ، (مالكَّ المُلكِ مبدعَ الأكوان)حيث تتجلى معاني الإحسـاس بالربوبية ،والضعف أمام قرة الله ـ تعالى - وسلطانه ومناجاتـه لربـه باسـمه الأعظم

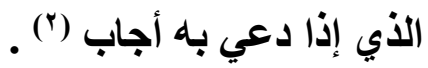

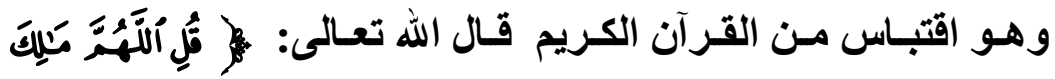

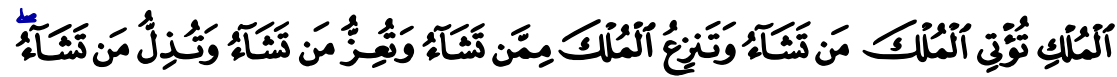

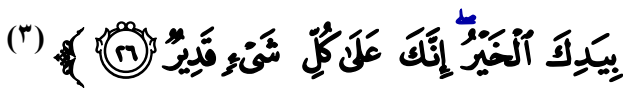

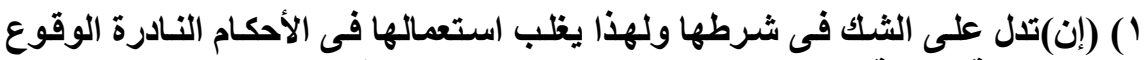

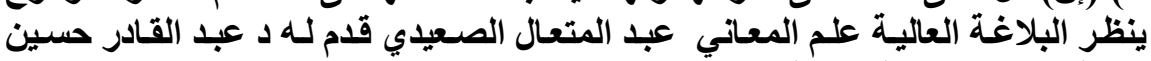

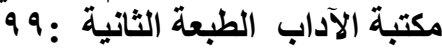

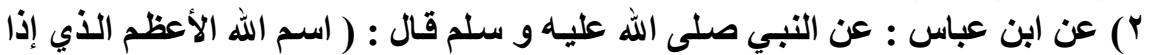

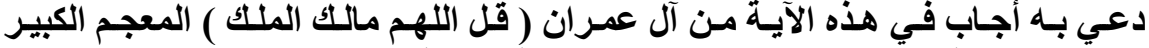

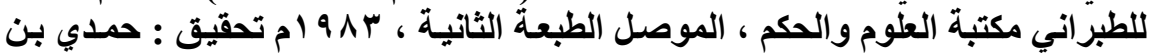

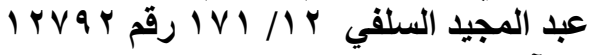

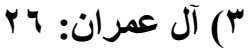


أي: (أنت الملك المالك لجميع الممالك، فصفة الملتك المطلث للك، والمملكة كلها علويها وسفليها لك و التصريف والتدبير كله للك )('). وقد تكرر هذا الاقتباس أكثر من مرة فبعد نداء شـامل لبنس جنسه و لقتب انتباههم إلى سعة ملك الله وعظيم قدرته يضرع إلى ربه ـتعالى- بمالك الملك مؤكدا تفردهـ تعالى - بالحمد والثناء باستفهام تقريري فيقول : تعلمُ الأرضُ قُرَه والسماءُ يا بني الأرض إنَّ للّهِ مُلْكَاً قادرّ دائماً على ما يشاءُ إن رباً يُدَبِّرُ ملكاً كهذا بينَ حرفين أمرهُما و القضاءُ حارتّ الخلقُ في تصور ذاتٍ

مَنْ لله الحمدُ غيرُه والثناءُ (ن)

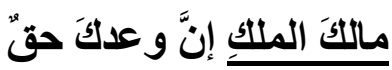
كما تكرر هذا الاقتباس في ثنايا التذكير ببعض مظاهر قدرة الله و عظمته ووحدانيته وسمو حكمته وإحاطته علمـا بكل مخلوقاته ، ومقدرته على البعث و القيامة حيث نادي : واقتداراً أحاط بالأكوان يا ابنَ حواءَ من أماتَ وأحيا بعدَ موتٍ بهيجة الأغصان يَبْعَثُ الأرضَ كلَّ عامٍ فتحيا في بساطٍ مرصنَع الألوان تُنْبتُ الحبَّ والثمارَ وتزَهو

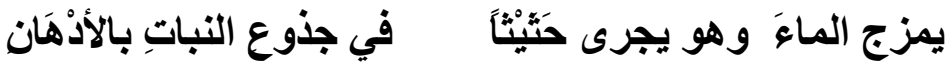

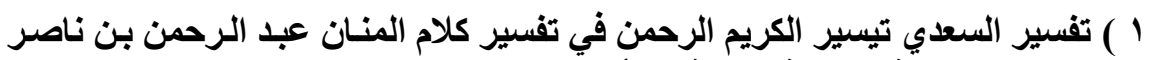

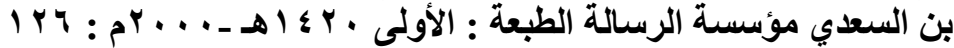

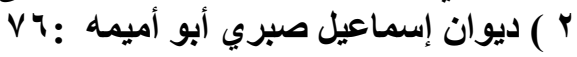


قدرةٌ أعجزتّ قوى التّبيان

ما بَدَا نُورُ سِرِّه في جنان

ضمَّها عِلمُهُه بأجْلي بَيَان

كلَّ يومج سُططائهُه في شَنَان

طِيّاتُ الأعمال بالإحسان

لم يصدِّقْ بدعوةِ الإيمان( )
كلٌّ شربٍِ لهله مذاقٌ وطعٌّ

قيضُ علم الحكيم ربِّ البرَايا

لم يدعْ ذرةَّ على الأرض إلا

مالكُُ الملكِ ناقدٌ الأمر فردٌ

خَلََّ الموتَ والحياةِ لتُجْزَى

وينالُ القِصَاصَ كلُّ أثثيم

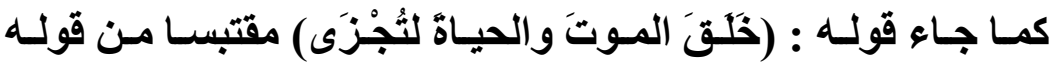

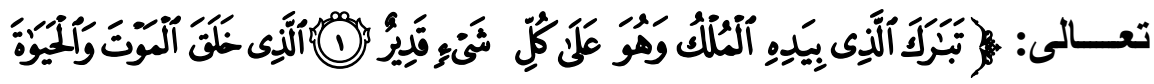

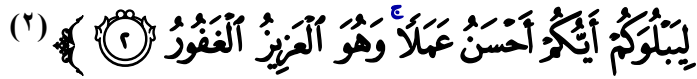

فالآية الكريمة تتحدث عن مظهر من مظاهر قرة الله ـتعالى ـممثلة

في خلق المـوت والحيـاة ( وأوثر بالذكر من المخلوقـات المـوتُ والحيـاة لأنهمـا أعظم العوارض لجنس الحيوان الذي هـو أعجب الموجـود على الأرض والأي الإنسان نوع منه )(") .

( ) ديوان إسماعيل صبري أبو أميمه : جها

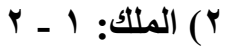

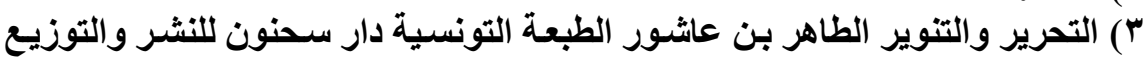


وكما قدم القرآن المـوت على الحيـاة قدمـه الثـاعر( لأنـه إلى القهر أقرب: وقيل: قدمه لأنه أقدم لأن الأثياء في الابتداء كانت في حكم الموت كالنطفة والتراب ونحوهما ثم اعترضت عليها الحياة)(') قال جار الله : ( قدم الموت على الحياة ، لأنّ أقوى النـاس داعياً إلى

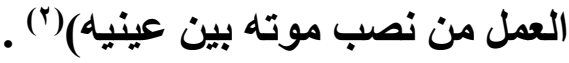

وكمـا ذكر القرآن العلة في خلق الموت والحيـاة وهى الابتلاء ذكر الشَاعر العلة ذاتها بشيء من التفصيل والإطناب والتقسيم فقال : ( لتُجْزَى

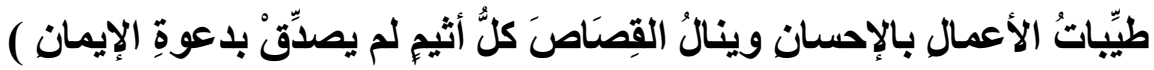
والفـرق كبير والبون شاسـع بين مـا ذكره القرآن مـن علـة لخلق المـوت والحياة وما صرح به الثاعر فقد سلك النظم القرآني طريق الاستعارة في

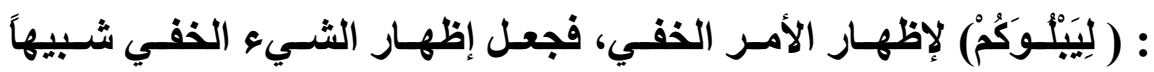

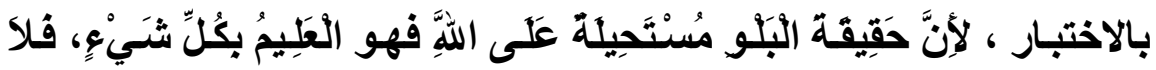

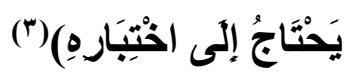
كما تكرر هذا الاقتباس أعنى: (مالكُ الملكِ) في ثنايـا حديث الثـاعر عن المؤمنين وما أعد لهم من ألوان النعيم حيث توجـه بالنداء للتعيم في صورة بليعة مطالبا إياه بتقليم التهاني للفائزين والموعودين :

(1) تفسير البغوي معالم التززيل أبو محمد الحسبن بن مسعود البغوي محمد عبد الله

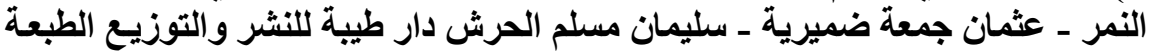

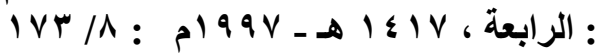

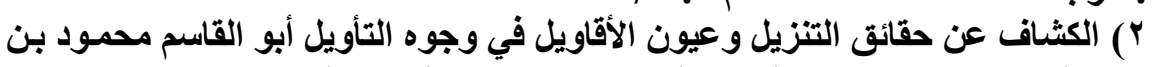

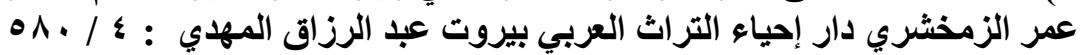

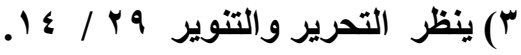




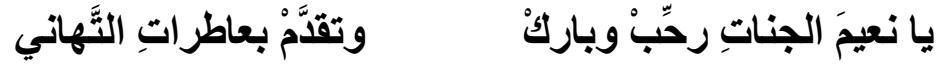

$$
\begin{aligned}
& \text { وابتسمْ يا جمالُ واهتف سلاماً وتألَّق في الحور والولدان }
\end{aligned}
$$

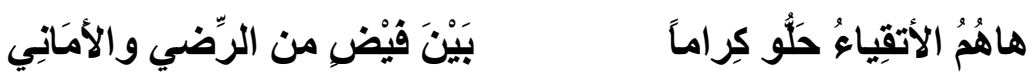

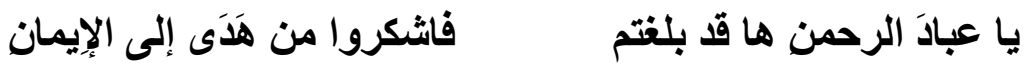

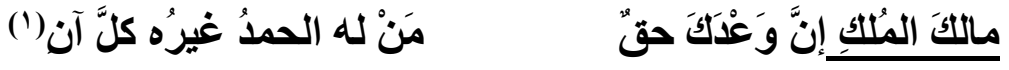

كما جاء الاقتباس القرآني واضحا جليا ، فبعد أن ضرع الشـاعر إلى

خالقه بأسمائه الحسنى وصفاته العلا :

جلَّ شَأنُ الإله ربِّ البرايا

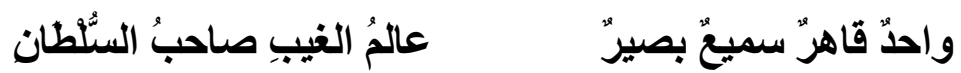

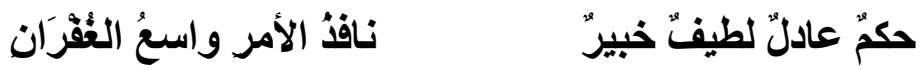

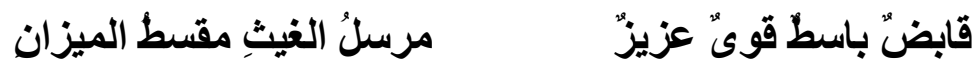

واجدُ ماجدٌ حليمٌ كريمٌ

جاء الاقتباس :

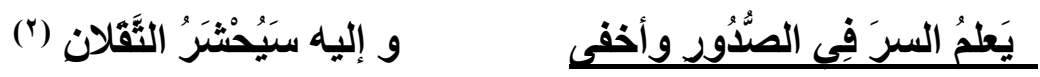

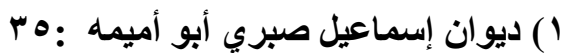

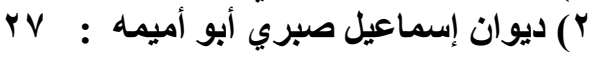




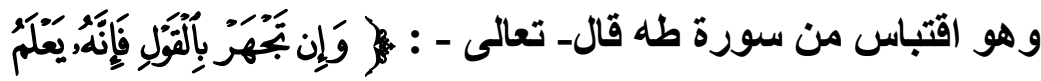

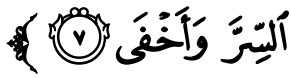

والسر كما قال الحسن: هو ما أسر الرجل إلى غيره، وأخفى من ذلك مـا أسر في نفسـه ولم يعلـم بـه أحد إلا اللّة ، وعن ابـن عبساس وسـعيا بن جبيز: السر ما تسر في نفسك وأخفى من السر ما يلقيه ـعز وجل- في قلبك

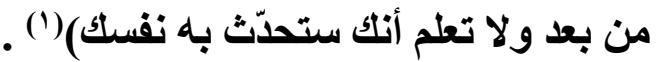
وقد قيد الشـاعر السر بكونـه في الصدور وهو مـا أطلقته الآيـة ولم تقيده ،لأن الآيـة جـاعت لبيـان إحاطتهـ ـ تعـالى ـ بكـل شـيء علمـا ، فكـان الإطلاق للتعميم حتى يشمل الكلام الخفي تفوه به المرع لغيره أو احتفظ بـه في صدره ، أما الشاعر فلعل الوزن هو ما دعاه إلى تقيده . ويتابع شاعرنا ثناءه على الله - تعالى- فيقول :

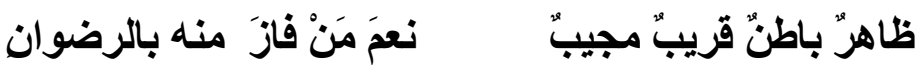

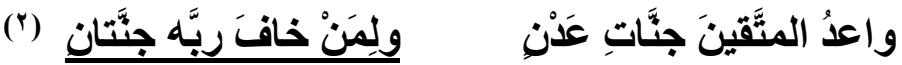

فيذكر أنسه جل في علاه ظـاهر بـاطن قريب مجيب مادحا الفـائزين برضوان الله ـ تعالى- مشيرا إلى وعد الله المتقين بجنـات عدن متخذا من

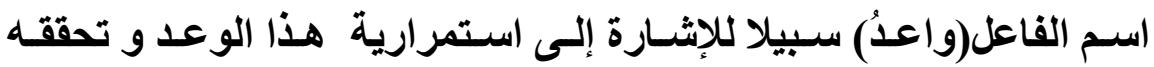
وتقريره بأنسه واقع لا مـراء فيـه ، ثم يـأتي الاقتبـاس: (ولِمَنْ خـافَ ربَّهـ 
جنَّتان) تأكيلا على وعد الله الذي لا يتخلف قِال الله ـتعالى -: (وَلِمَنْ خَافَ

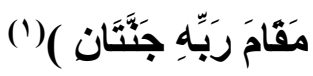

فالآية الكريمة تبين مقام المؤمنين الذين يخافون ربهم ، ويطيعونهـ

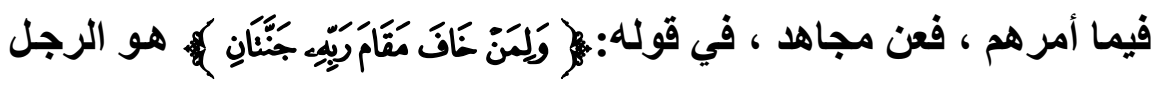
يهم بالذنب، فيذكر مقام ربه فينزع)(") فمعنى (مَقامَ رَبِّهِ ) موقفه الذي يقف فيه العباد للحساب يوم القيامة ،

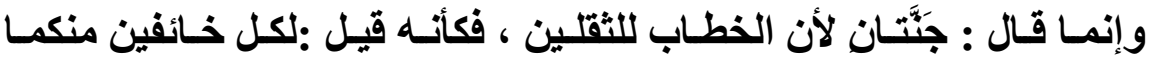
جنتان : جنة للخائف الإنسي ، وجنة للخائف الجني. ويجوز أن يقال : جنة لفعل الطاعات ، وجنة لترك المعاصي ، لأنّ التكليف دائر عليهما وأن يقال : جنة يثاب بها ، وأخرى تضم إليها على وجـه التفضل)(") ويَجُوزُ أنْ تُكُونَ

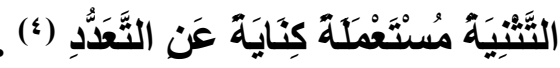

هذا وقد اقتبس الثـاعر الآيـة كلهـا إلا أنـه للحفـاظ على وزن البيت وزيادة في الرهبة والخوف جعل الخوف من الذات العلية (خاف ربه )ممهدا

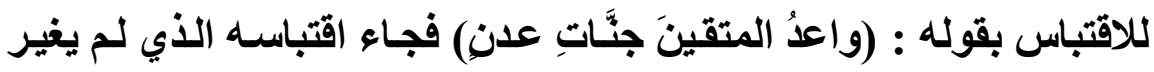
فيه كلمة سسوى عدم ذكر المقام -حسن الموقع مستقرا في محله غير قلق .

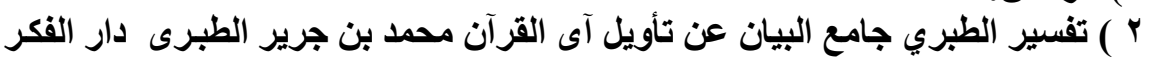

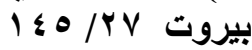

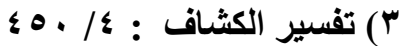

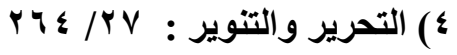


وقد تكرر هذا الاقتباس مع اختلاف طفيف فبعد الإخبار عن تقديس كل شيء لعظمته وأنـهـ تعـالى- وارث الأرض والسماءِ جميعـا يوم القيامـة

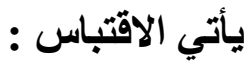

في دواجم فريضةُ الشكُران خير هادِ لنعمةِ الإيمان يومَ نادَي القضاءُ آنَ أوانِي

ولمن خاف نِقِمَتِى جنَّتان (1)
سَبَّحَ اللهَ كلُ شيعٍ لَتبْقِى جلَّ شُأنُ القدير ربِّ البَرايا وارثِ الأرض وض السماعِ جميعاً قوله الحقُّ إذ يقول اخثوني

والفرق واضح فهناك لم يغير كلمة من كلمـات الآيـة الكريمـة أمـا هنـا

$$
\text { فقد استبدل قوله : ( ربه )بقوله :( نِقَتَي) . }
$$

وبعد الإشارة إلى عظيم نعم الله ـ تعالى- وعجز الخلق عن عدها

جاء ثناؤه على اللهـ تعالى- مقتبسا من سورة فاطر:

كي يُوَّدِى فرائضَ الشُُكْران

س فحمداً للمُنْعِمِ المنَّان

باسط الرزق دائمُ الإحُسنَان
كلٌ شَيعِ يُسَبِِحُ اللهَهَ حمداً

نعمُ سـاقها المُهَيْنُِ للنا

أعْجَزَ الخلقَ عدُّها فَتعَالى

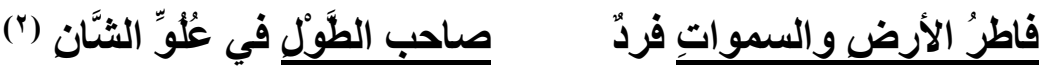

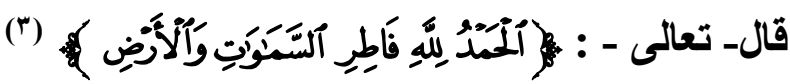

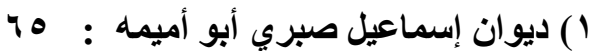

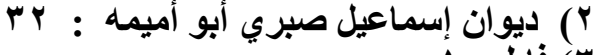

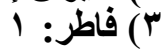




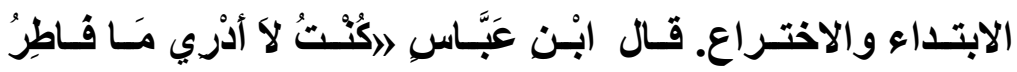

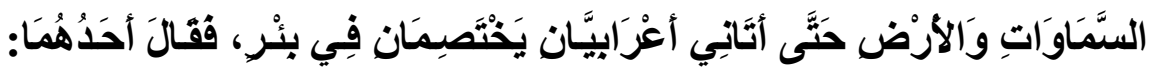

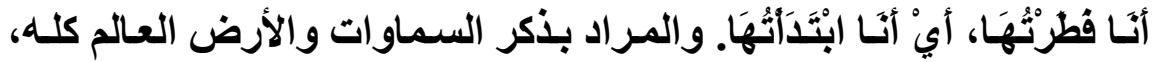
ونبه بهذا على أن من قدر على الابتداء قادر على الإعادة."(1) وأمسا تقـــيم الســموات على الأرض فلثـرفها و تقــدم خلقهـا على

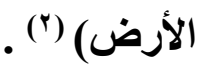

و قد خـالف الشـاعر الآيـة حيـث قدم الأرض على السـموات ولعلـهـ قدمها لمناسبة الحديث عن سوق نعم المهيمن للنساس وعجز الخلث عن

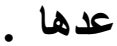

ثم جاء قوله:(فرد صاحب الطَّلْ في علو الثـان ) وهو اقتباس من

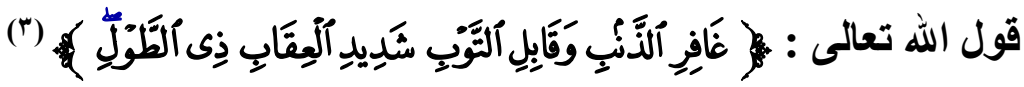

قـال ابن عبساس: (ذِي الطَّوْل) يعنـي: السـعة والغنى ، والمعنى: أنـه المتفضل على عباده، المتطول عليهم بما هو فيه من المنن والأنعام التي لا يطيقون القيام بثكر واحدة منها)(؛) .

() تفسير القرطبي الجامع لأحكام القرآن محمد بن أحمد شمس الدين القرطبي تحقيق :

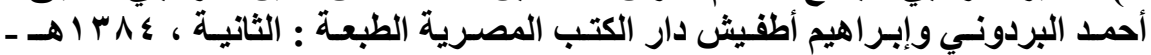

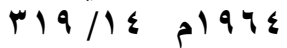

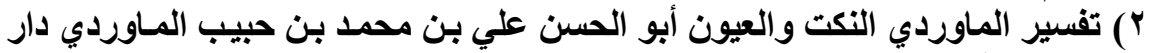

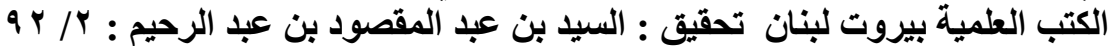
r

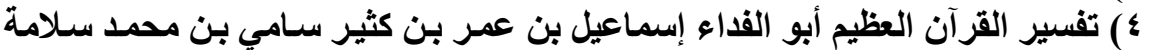

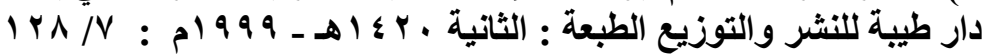


ثم ذكر الثناعر ما يدل على سعة علم الله وشـوله لكل مـا في الكون

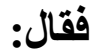

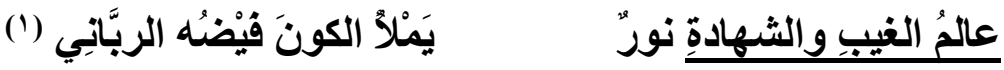

وهو مقتبس من قول الله تعالى :(عَالِّمُ الَفْيْب وَالثََّّهَادَةٍ ) وقد تكرر

$$
\text { في القرآن عشر مرات (") . }
$$

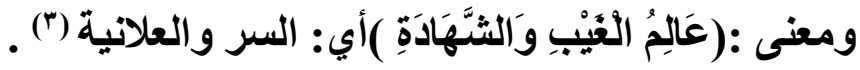

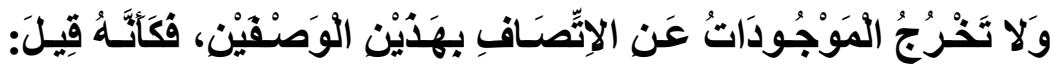

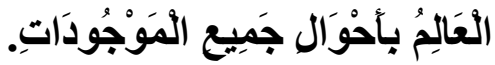

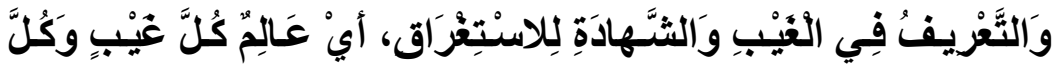

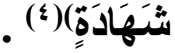

وهذا الاقتباس مناسب وموضح لصاحب الطول إذ المنعم والمتفضل

على العباد لابد وأن يكون عَالِما بأحْوَال جَمِيع الْمَوْجُودَاتِ.

ويتجلى فيض الله الرباني الذي يملأ الكون في غفران الذنوب ولذلك قال :

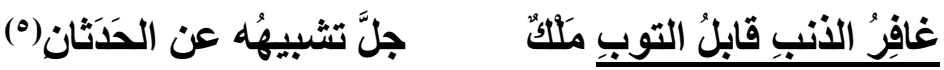

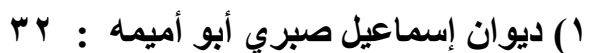

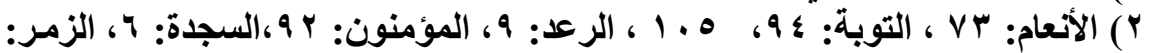

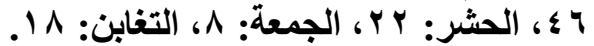

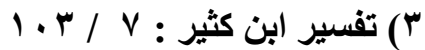

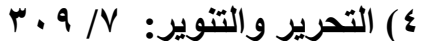

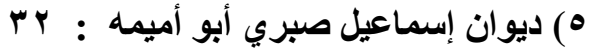




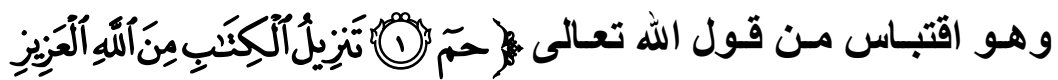

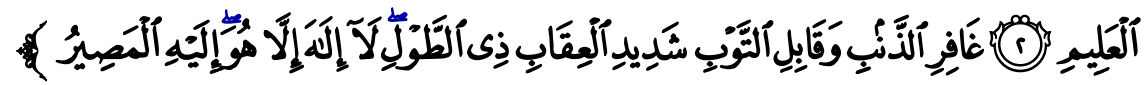

فهو سبحانه يغفر سائر الأنوب للمؤمنين وقايل توبة من تاب من عباده .

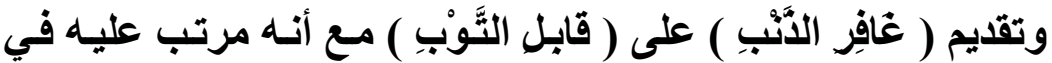

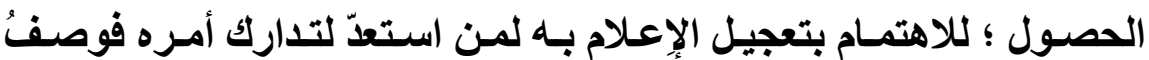

( غافر الذنب وقابل التوب تعريض بالترغيب)(') .

وهذا من فيض الله -تعالى -وكرمه (فربما يغفر من غير توبة)(؟) .

وقال:( غافِرِ الَّنَب ) ولْم يقل الذنوب، لإرادة للجنس والمعنى سـاتر

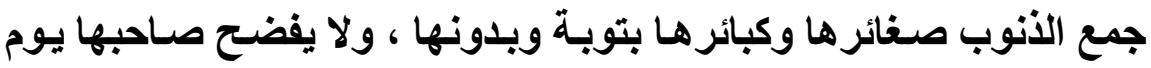

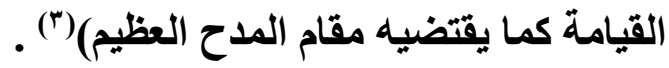

وقد خـالف الثـاعر النظم القرَّى فلْم يعطف ( قابل التَّوبْ ) على

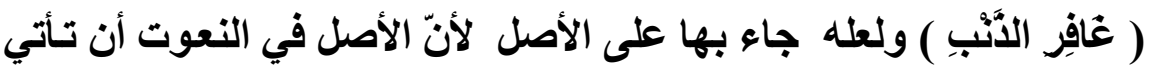

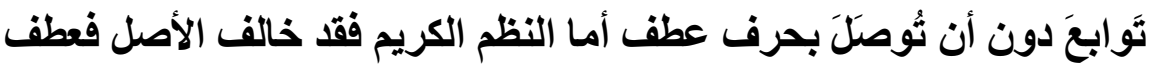

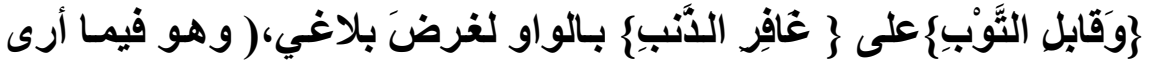

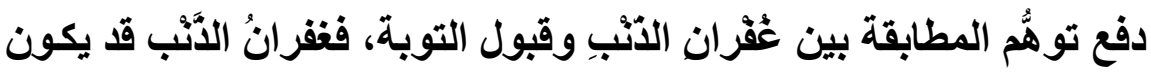

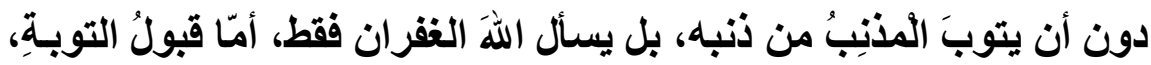

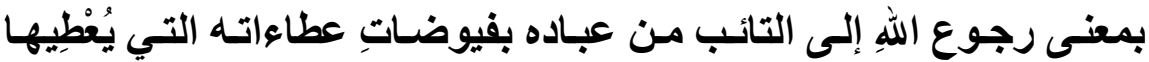

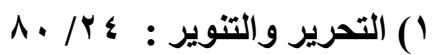

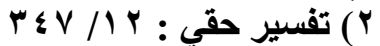

$$
\begin{aligned}
& \text { r) تفسير حقي : Y }
\end{aligned}
$$


المتقين إذا كان منهم، أوَ الأبرار أو المحسنين إذا كـان منهم، فهو شيء"

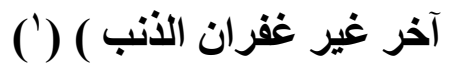

وهذا الاقتباس جاء متوافقا ومكملا ومتناسقا ، فبعد أن أثنى الثـاعر

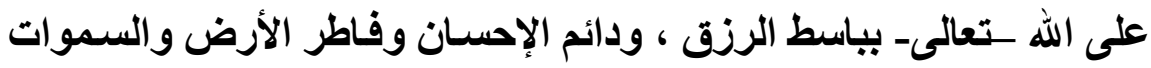
، وعالم الغيب والثهادة وكلها صفات لله أزلية منزهة عن التجدد والتقيد بزمان دون زمان جاء :(غافز الذنب قابل التوب) كنلك اسمي فاعل يراد

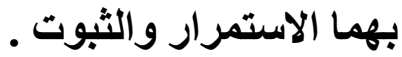

$* * * * * * * * * * * * * * * * *$

1) البلاغة العربيـة أسسـها وعلومها وفنونهـا عبد الرحمن حبنكة الميدانى دار القلم

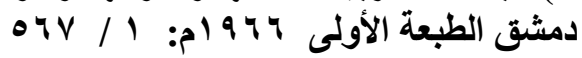




\section{المبحثُ الأثاني}

\section{التذكير ببعض مظاهر قدرة الله تعالى :}

ساق القرآن الكريم ألوانـا من البراهين السـاطعة والحجج الواضحة الألـة على وحدانيـة الله ـ تعـالىـ وقدرتـهـ وهـي بـر اهين كونيـة حسية مشاهدة، لا تحتاج لكثير من التفكر والتأمل والتعقل، وإنمـا تحتـاج للانتبـاه لها، وفهم مدلولاتها، ومـا تؤديـه من فوائد عظيمـة أوجدها الخـالق ، لنفع

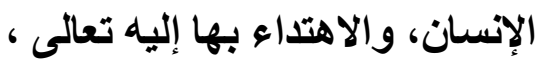

وقد استـعرض الشـاعر جاتبـا مـن تلـك الـلائل معتمـدا على القرآن الكريم مقتبسا منه ومتأثرا بلغته ،

فبعد التّذكير ببعض مظـاهر قدرة الله ـ تعـالىـ في خلق السـموات والأرض وما فيهما من مخلوقات خضعت جميعا لقدرته : وجلالاً وكبَّر الخافِقان سجدَ الكونُ للمهيمن شكراً تتجلى القدرة في بعث العباد ومحاسبتهم ومجازاتهم فهو سبحانه: وكذا الحيَّ من رَمِيْمِ فَان

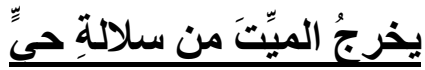

هثَّمتهها تققلبِاتُ الزَّمَانَ (1) يَبْعَثُ الخلقَ من دَيَاجِى قبور 
وقد اقتبس الشـاعر هذا اللاليل السـاطع على كمـال قدرة الله ـتعالى في إخراج الأثياء من أضدادها، بـإخراج الميث من الحي، وإخراج الحي من الميث، وإحياء الميت، وإماتـة الحي من القرآن الكريم قال ـتعـلىـ- :

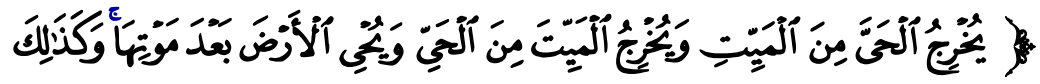

(1)

وكلمة (الحَيّ و المَيِّ) في هذه الآيـة، تستعمل حقيقة ومجـازا، أمـا الحقيقت: فهي المني يخرج منـه الإنسـان، فعن ابن عباس قولـه:( يُخْرجُ

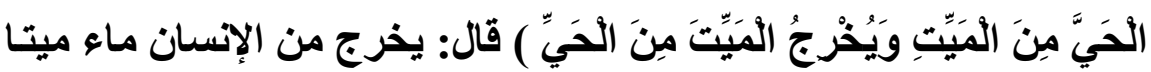
فيخلق منه بشرا، فنلك الميث من الحي، ويخرج الحي من الميت، فيعني بذلك أنه يخلق من الماء بشرًا فنلك الحي من الميت .

وأما المجاز: وهو على سبيل استعارة الحي للمؤمن، والميت للكافر

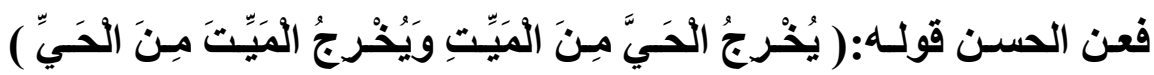

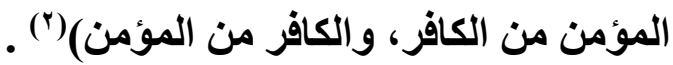

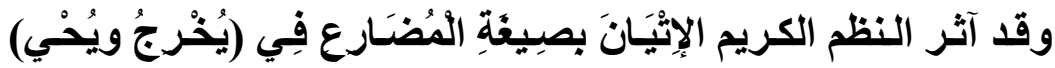

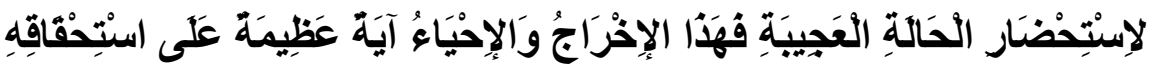

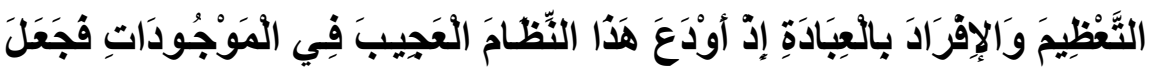

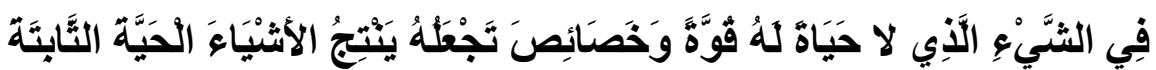




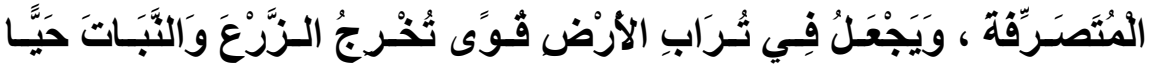

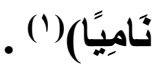

وقد أفاد الثاعر من هذه النكات البلاغية متصرفاً في الاقتباس كما

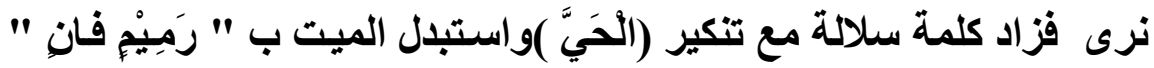
والثـاعر بذلك يبرز- بقصد أو بدون قصد - جانبا من إعجاز القرآن الكريم الماثل في دقة الصياغة و روعة التعبير وحسن النظم وجودة البلاغة في

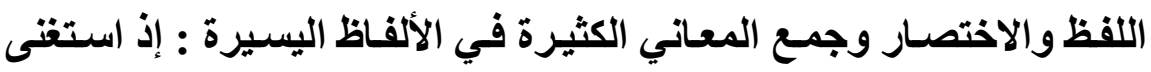

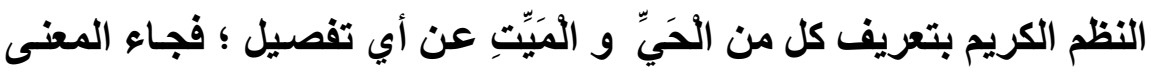

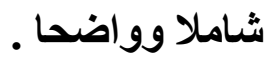

وبعد إلقائه الضوء على جانب من جوانب جهاد رسول الله ـ صلى

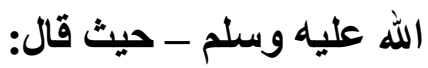

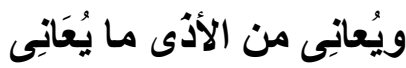
ظلَّ يَهْبِى إلى صراطِ سوى

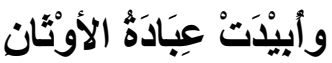
جاهًَ المشركينَ حتى هَََاهُم

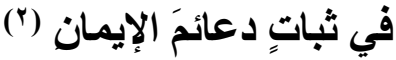
فوقَ أنقاض جهِِهم كانَ يَبْنِى توجه بالنصح والإرشاد لابن آدم داعيا إياه إلى اغتنام أيام عمره قبل

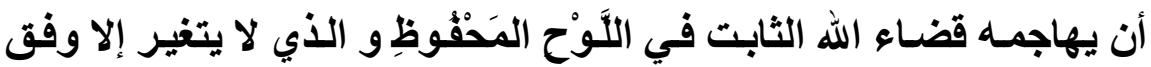

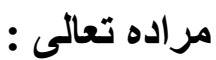

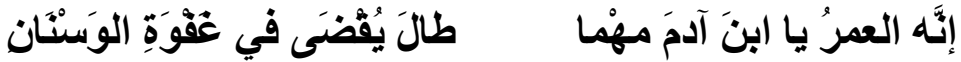

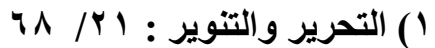

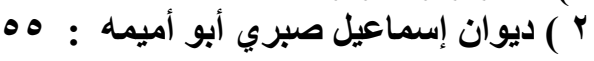




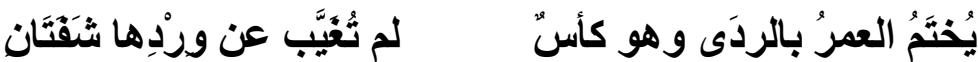
قر قضَنَاه المُحِيْط بِالأكْوان

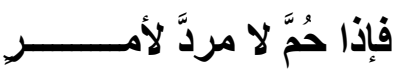

منْ قديم الآبادِ والأزْمَان

خَطَ في اللَّوْح ما قضضَى للَبرََايا

وبأمِّ الكتابِ أصلُ البَيَان (1)

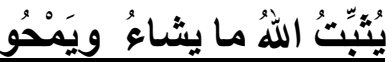

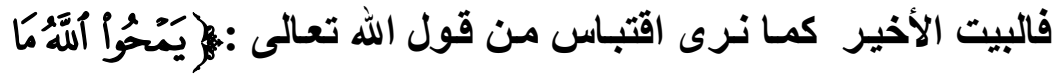

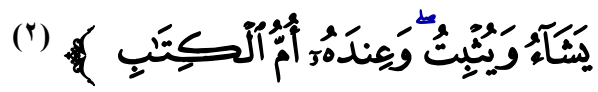

وقد غير الشاعر في الاقتباس : فقدم الإثبات على المحو ، ولعله فُعَلَ

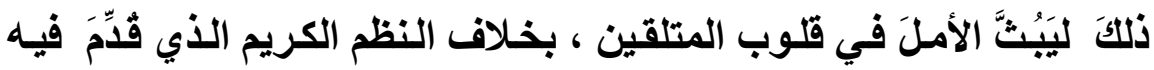
المحوُ على الإثبات ليناسب مقام التهديد للمشركين الذين طالبوا رسول الله ـ صلى الله عليه وسـلم - بالإتيـان بخارقةٍ ماديّة وتوهموا أن تأخر الوعيد

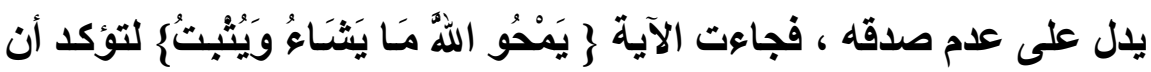
محوَ الوعيد أو تأخيره لا يـل على عدم حصوله فِإنَّ لذلتلك آجـالاً أرادهـا الله واقتضتها حكمته وهو أعلم بخلقه وشؤونهم ) (") .

أو لأن المحو أدل على القدرة من الإثبات ، ولذا قدم المحو .

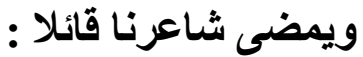

1) الريوان إسماعيل صبري أبو أميمه : 1)

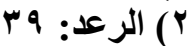

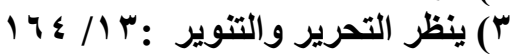


طاعة العبد لِلنّدّاء الرَّبَّني حينَ نادي مُسَِِِرٌ الأكوان

تذكرُ اللهَ خيفة كلّ آن

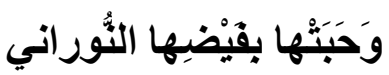
كلُ نَجْمُ يَدُورُ في حُسنبَان

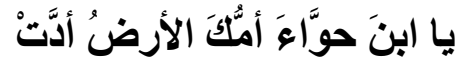
جاءت الأرضُ والسمواتُ طوعًا سابحاتُ الأفلاكِ في كلِّ بُرْج

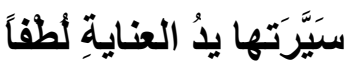
باسم ربِّ السَّماعِ كالبرق تَجْرى قدرةُ الخالق العليم تَعَالَى

فبعد الاعوة إلى الثَّكُّل في ملكوت الله ، والتدبر في عجائب صنعه ، يتوجه شاعرنا بالنصح والإرشاد لابن حواء ضـاربا لـه نمـاذج عدة لكمال الخضوع والانقياد والامتثال التام لأمر الله ـتعالى- فعلى نهج سورة الرحمن في تعداد بعض مظاهر قدرة اللهـ تعـالى- يعدد الثـاعر بعض دلائل القدرة والوحدانيـة من أرض و سماء وأفلاك و نجوم تسبح في الفضساء بحسـاب متقن، لا يختلف ولا يضطرب ، مشيداً بهذه القدرة الإلهية والتي تدبِّرُ كلَّ

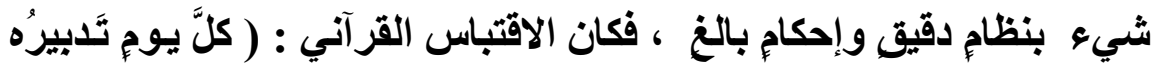
في شَّان ) أقصر الطرق وأفضلها إفصـاحا عن مراد الشــاعر حيث تكفل

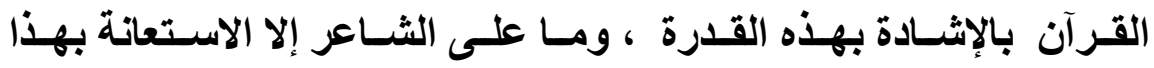
الاقتباس و التمهيد له ليقرَّ في مكانـه ،مؤديـا دوره المنشـود ، قال تعالى :

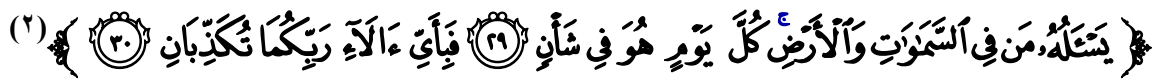


قال الحسين بن الفضل : (هو سوق المقادير إلى المواقيت ومعنـاه إن الله ـعز وجل ـ كتب ما يكون في كل يوم ، وقدر ما هو كائن فإذا جاء ذلك الوقت تعلقت إرادته بالفعل فيوجده في ذلك الوقت )(' ) .

وقد تكرر هذا الاقتباس في ثنايا حديث الشاعر عن جاتب من جوانب قدرة اللهـ تعالى- ورحمته بعباده حيث ذكر الشمس ومـا تبثه للوجود من حياة ، و الأرض ومـا أودع فيها من كنوز وأقوات وأن كل شيء في الوجود خاضع لعلمه تعالى - وحكمته : لم يغب عنصر عن الأرض مهما عز بعا عن عالم الإمكان خيرَ مهرِ لدولةِِ الإنسان تمَّ للأرض أمرُها حيثُ باتتن باسط الرزق مقسط الميزان بارك اللهُ ما بها و عَلِيها لم يَغِبْ نورُ ذَاتِهَه عَنْ مكان مَنْ كربِّ العُلا تفرَّد حُكماً وله التَّجمُ والََّّرى يَسْجُدَان بيْنَ حَرَين كلَّما شَاءَ يقضى من لَالْنهاه جَرَى بـه حَرْقان مُطلقُ الحكم لا مَرَدَّ لأمر ضَمَّ أطوَارَها دَقَيقُ البيان لم يُغادرْ نفساً على الأرض إلا كلَّ يومج أقدارُه في شَان سنة الخالق العظيم تجلَّت

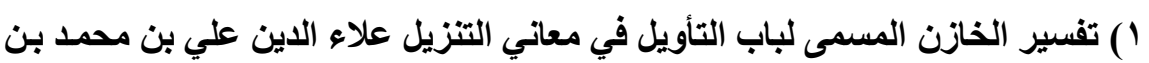

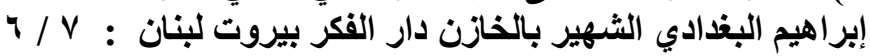


ثم أثشار الثاعر إلى شمول علم الله-تعالى- لكل شيء ، وعلم تنـاهى

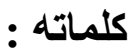

وأمَدَّ البحارَ سبعُ دَوَان

كلماتُ المُحيطِ ربِّ البيان(')

\section{لو أجاجُ البحار صارَ مِدَادَاً}

تَفِدَ الماءُ قبِلَ أنْ نَتَقْضَّى

والشاعر كما نرى قد اقتبس هذا المعنى من آيتين مختلفتين من كتاب

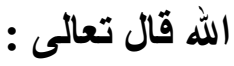

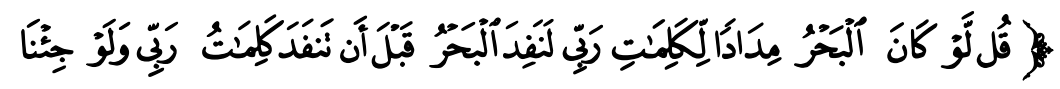

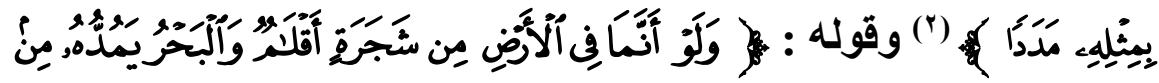

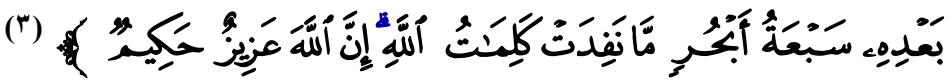
والآيتـان تناولتـا سـعة علـم الله - تعـالى - بيــ أن بينهمـا فرقـا فآيـة الكهف تحدثت عن المداد وأنه لو كتب علم الله بمداد البحر لتفد البحر ولم ينفل علم الله ، وكذلك لو جيء ببحر آخر مثله ، وذلك لأن البحر متناهِ وعلم الله غير متناه ، أمـا آيـة لقمـان فقد جمعت بين المداد والأقلام أي: ولهو أن جميع أشجار الأرض جعلت أقلامسا، وجعل البحر مدادًا ومَدهاه سبعة أبحر معه، فكتبت بها كلمـات الله الدالـة على عظمته وصفاته وجلالـه لتكسرت

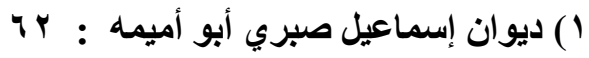

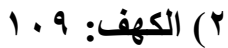

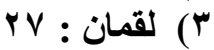


الأقلام، وتَفََ ماء البحر، ولو جاء أمثالها مَدَدا وهذا من بـاب تقريب المعنى إلى الأذهان ، لأن هذه الأشياء مخلوقة ، وكلام الله غير مخلوق . والمتأمل في الاقتباس يجد أن الشـاعر قد مزج بين الآيتين فأحسن الصياغة وأجاد في رسم صورة جمعت بين ما اشتملت عليه الآيتان . وبعد حديث طويـل عن آلاء الله في خلقهـه وأفضـاله عليهم يقتبس الشاعر تلك الحقيقة القر آنية التي تؤكد عجز العباد من تعداد نعم الله تعالى فضلا عن القيام بشكرها فيقول :

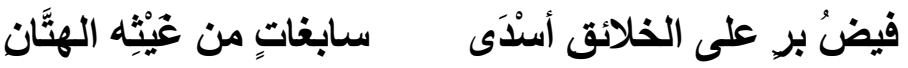

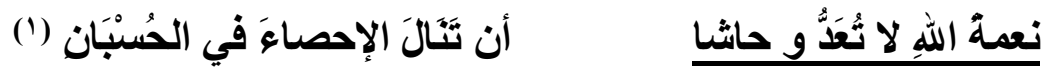

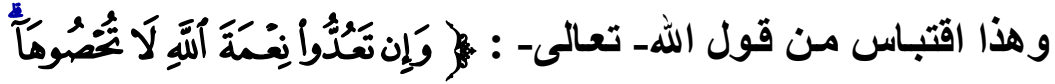

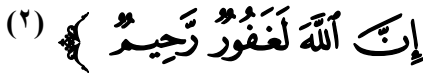

فالآية إخبار من الله عن عجز العباد عن تعداد نعمه عليهم فضلا عن القيام بشكرها متخذة من الشرط المصدر بـ (إن) التي تستعمل في الأمر المشكوك فيه ،والمعنى (لو وُجدت الإرادة فليس هنالك قدرة على استيعاب نعم الله ، لأن نعم الله فوق طاقة مقدور البشر )("َ) وهو مـا أراده الثـاعر و قصده من اقتباسـه ، وأفـاد منـه إلا أنـه تصرف في الاقتبـاس عارضـا تلكت

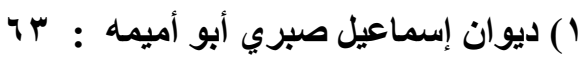

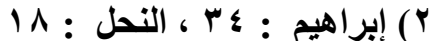

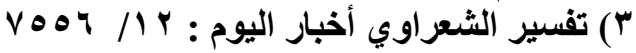


الحقيقة في صورة خبر استقر : (نعمة الله لا تعد) ، منزهـا إياهـا من أن ينالها عد أو إحصاء.

وبعد تحذير من غواية الثيطان والوقوع في شراكه تأتى النصيحة

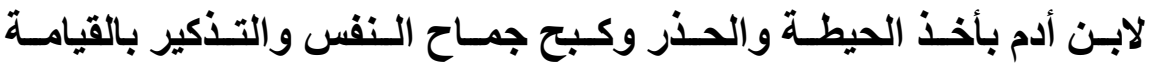
وأهو الها، والساعة وشدائدها مقتبسا من القرآن الكريم ما يدل على اليأس

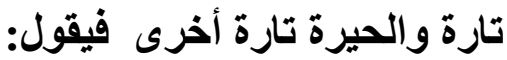

كيفَ سوَّاَكَ خالقُ الأكُوْان أيهُها الجادُ الكنودُ تَذَّكَّر في جَلَل المُهَهْمِن الرَّحمَن

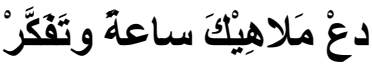

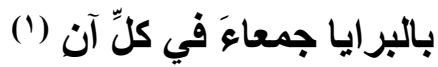

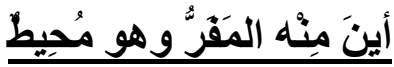

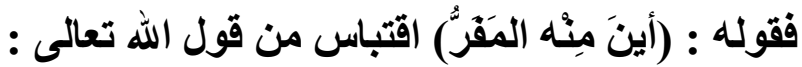

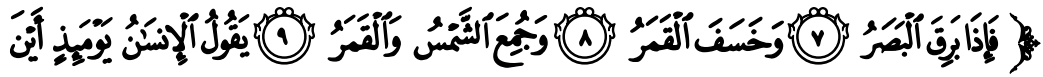

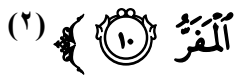

والثـاعر تصرف في الاقتبـاس بذكر المتعلق (مِنْهة) لأنسه جـاء بعد حَضِّ على ترك الملاهي والتفكير في جلال المهيمن الرحمن ، أمـا الآيـة الكريمة فهي تحكى مقولة الإنسان الكافر اللاهث على أمل في الفرار ممـا

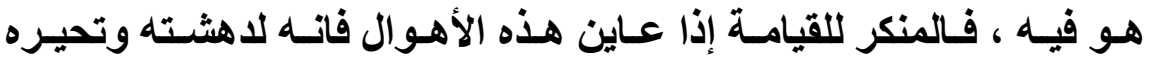

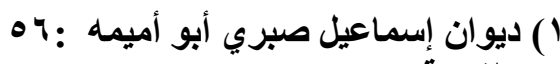

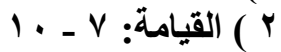


يتســاعل : هـل مـن ملجـأ أو موئـل أو مهـرب ؟ اسـتفهامـا حقيقيـا ،أو هـو استفهام مجازى معبر عن مدى يأسه فيقول قول الآيس ، لعلمه بأنه لا مفر منه إلا إليه) (')

كما تكرر هذا الاقتباس في ثنايا حديث الثاعر عن البعث والحساب :

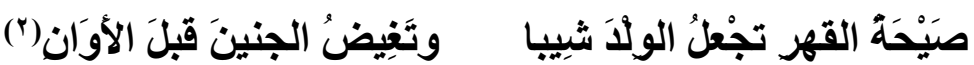

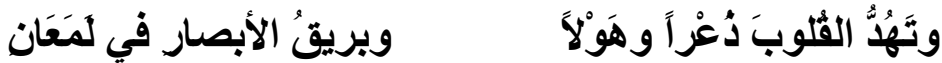

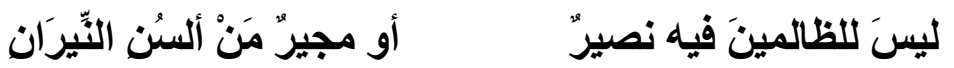
حمُه الحكمُ لا يُبََّلُ لفظظ

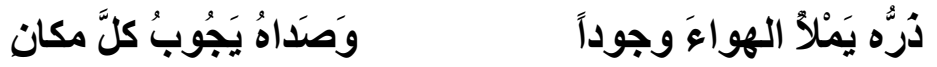

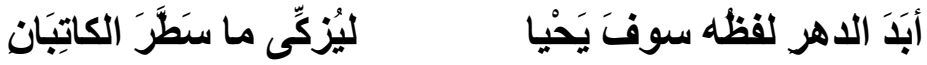

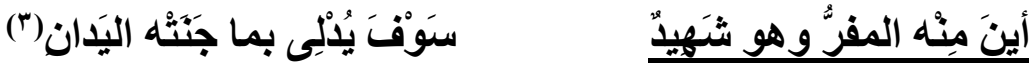
فلا فرق بين الموطنين سوى ثنائه على الذات العلية بمـا يناسب كل موطن من الإحاطة أو الثهادة ، كما لا يخفى أن قوله : (ليسَ للظالمينَ فيه

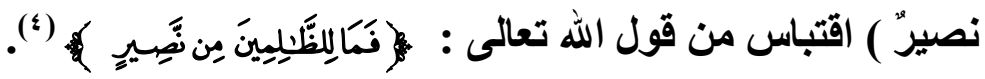

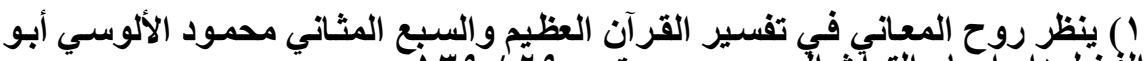

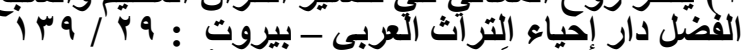

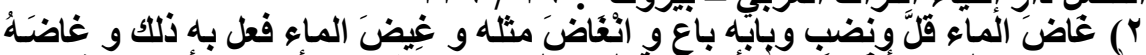

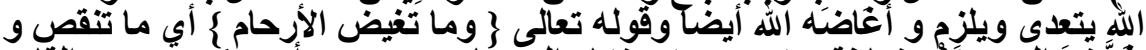

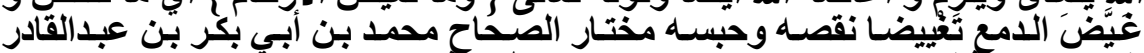

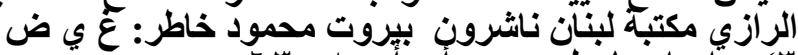

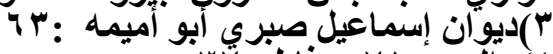
\& 
كما جاء الاقتباس واضحا جليا في ثنايا حديث الثـاعر عن قدرة الله تعالى في خلق السماء والأرض وما فيهما من عجائب الصنع وبائع القدرة وحسن الشكل، وقوة التركيب ومتانة البناء، فيقول :

واحدٍ في العُلا وفى السلطان هلْ لذهذا الوُجُودِ غيرَ إلذٍِ مطلقُ الحكم مبدعُ الأكوان أمرهُ الأمرُ لم يُشَبَّه بثَئ

واجبَ الحمدِ ما بدا الملوان سبَّحَ النَّجمُ في السماء يُؤدِّى إذ بناها قوية البُنيان تَمَّ أمرُ السماعِ سبحانَ ربيى

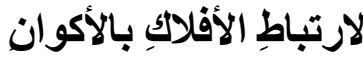
خلقَ الأرضَ جذوةَ من شهابِ

وَهَبَ الأرضَ سرعة الدوران(')

ودَحَاها منْ بعدِ ذَلكَ دَحْيًَ

فالثاعر كما نرى قد اقتبس حديثه عن خلث السماء و الأرض من

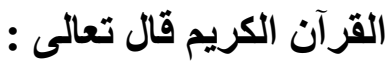

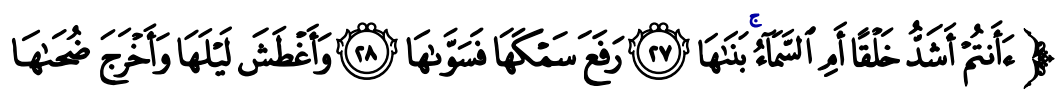

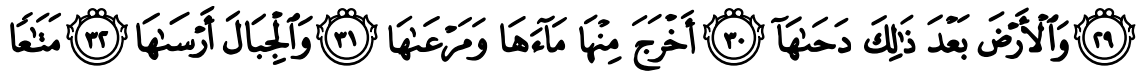

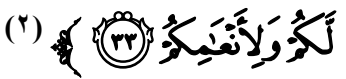


فهذه الآيات وردت في مقام التقريع والتوبيخ لمنكري البعث كاشفة لهم أن إعادتهم إلى الحياة ، ليست بأصعب من خلق السموات والأرض . وقد آثر النظم الكريم التعبير عن خلق السـماء بالبنـاء للإثـارة إلى تشبيهها بالقباب المبنية على سكنتها (1). كما آثر النظم دحاهـا للأرض أي بسطها وأوسعها ولم يقل والأرض بعد ذلـك خلقها، لأن خلقهـا تـم قبـل خلق السـماء و إنمـا دحيت بعد خلق الســاء بمعنى أنـه أودع فيهـا منافعها (؟)وهذا منتهى الإحكام في اختيـار اللفظ المناسب.

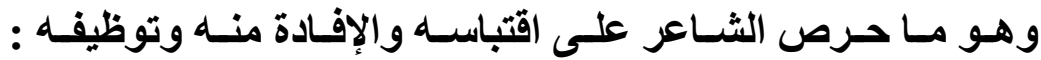
فالسماء بناها قوية البنيان و الأرض دحاها من بعد ذلك دحيا . ويمضسى الشـاعر في استعراضـه لبعض مظـاهر القدرة في النظــام

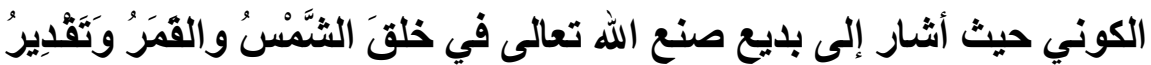

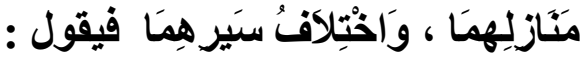

حول سيَّار ها وسِرْ في أمَان

$$
\text { ثُمََّّ أوحى للبدر أن خُذْ مداراً }
$$

ومنَ الشمس خذّ ضياعَكَ فَاعكِنْهُ عليها للستَّرب الوجلان

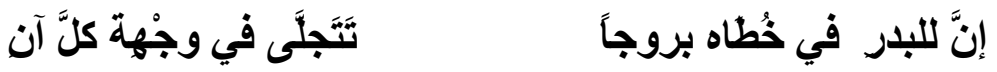

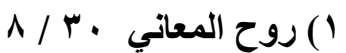

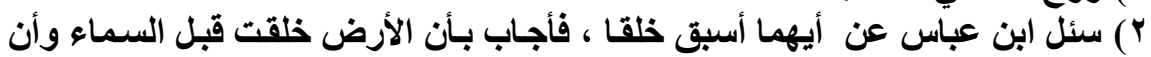

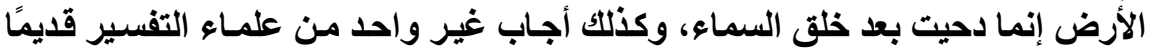

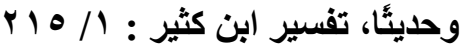




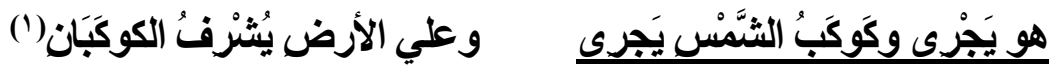

فالثـاعر قد اقتبس من القرآن الكريم حديثه عن تلك الآيـة الكونية ممثلـة في لزوم الثـمس والقمر مسـارً سـماوياً دائمسا وفق نظـام محكم لا يخرجان عنه، قال تعالى :

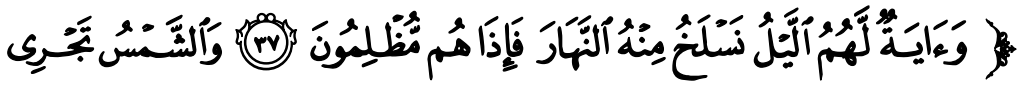

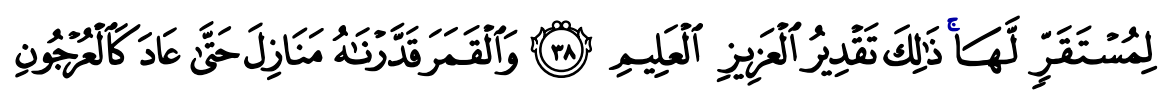

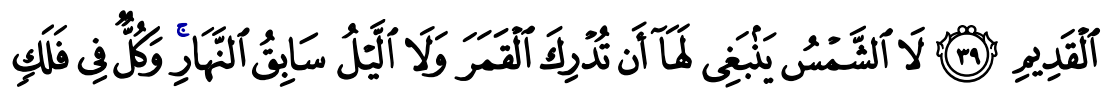

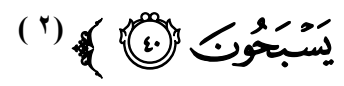

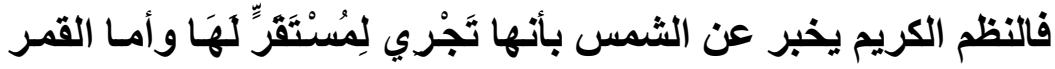
فينتقل في منازله حَتَّى عَادَ كَالْعُرْجُون القِدِيمِ . هذا وقد تصرف الشـاعر في الاقتبـاس تصرفا لم يكن موفقا فيها إذ جعل للبـدر خُطى وجعـه يجرى كجريـان الثـس وكأنهمـا يتشـابقان دون هدف أو غاية . ت ن

ثم يتابع الشـاعر حديثه عن مظاهر قدرة الله تعالى ورحمته بعباده

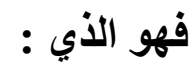

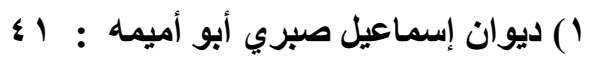

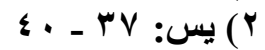


لبقاعِ الحياةِ في عُلِقوَان

ض غُيُونَاً مِنْ خيرها الهَهَّنَن

ما يُنَتِّى جواهرَ الأبدان

بحنانِ لم يؤتِهِ الوالدان

وعَليلا فوقَ الثَّرى يجْريان

ومعاشَاً كلاهُما آيتان (1)
خلقَ الثَتَّمَسَ رحمة وحنَانَاً

و أفاضتَ يدُ العطاعِ على الأر

بعد تقدير قوتِها أودعتها

نعمةُ الخالق الحكيم فأكرمْ

سَخَّرَ المـاءَ والههواعَ فُراتاً

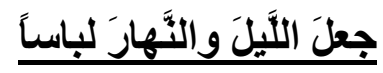

فالثَاعر يشير إلى جاتب من رحمة الله بعباده ممثلا في إنزاله القطر

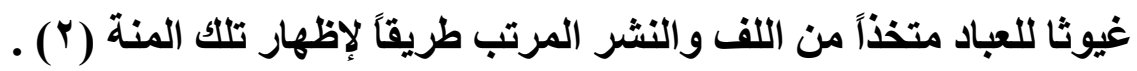

$$
\text { مقتبساً من القرآن الكريم قال تعالى : }
$$

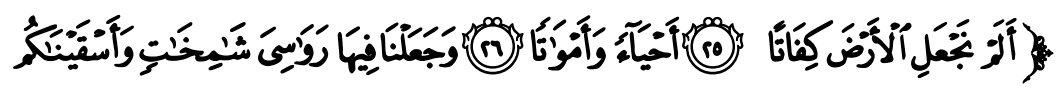

(")

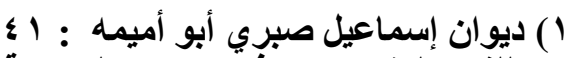

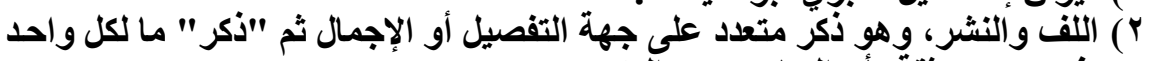

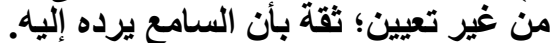

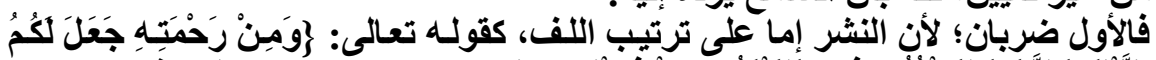

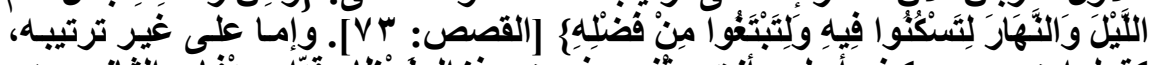

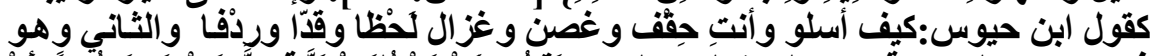

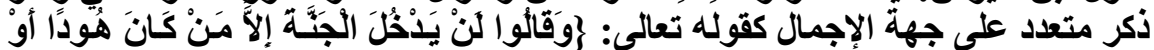

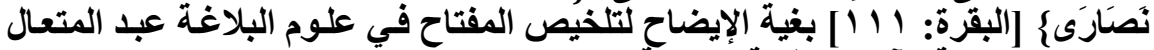

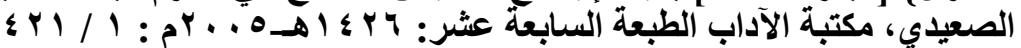

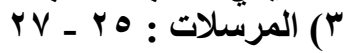


كما أشثار إلى نعمة أخرى ومنة كبرى امتن الله بها على عباده حيث جعل الليل مظلماً ليسكنوا فيه ، والنهار مبصراً لابتغاء الرزق وهو اقتباس الهاس

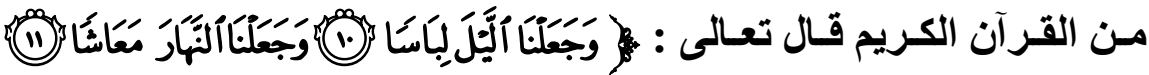

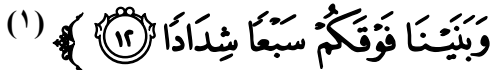

فقد امتن الله تعالى على العباد بهذا النظام المحكم الذي فيه اللطف بهم وراحة حياتهم ، فقد جعل الليل لباسـا أي كاللباس الذي يغطي البلدن

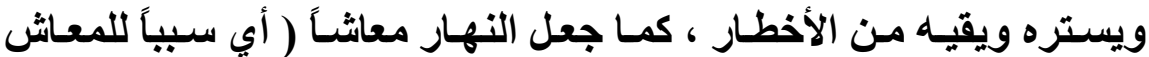
و التصرف في المصالح قال ابن عباس تبتغون فيهه من فضل الله ومـا قسم

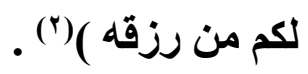

كما آثر النظم فعل \} جعلنا \{ لأن النوم كيفية يناسبها فعل الجعل لا فعلُ الخلق المناسبُ للأوات ) (").

وهذا ما اقتبسـه الثـاعر إلا أنسه تصرف في الاقتباس فجاء بـه على سبيل اللف والنشر المرتب وأخرجه في صورة جديدة تتمشى مع سـابقتها 


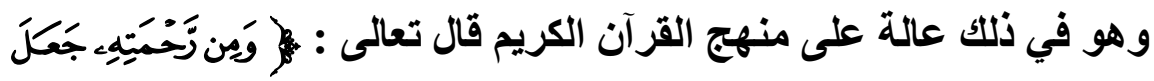

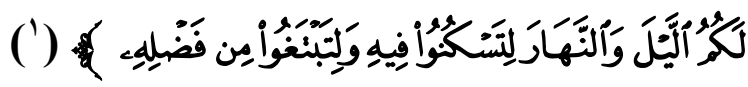

ويتابع الشـاعر حديثه عن دلائل وحدانيـة الله وكمـال عظمته ونفـاذ

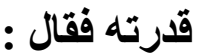

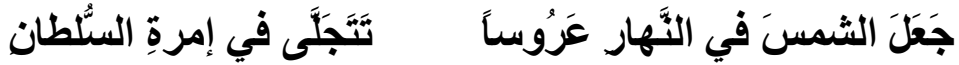

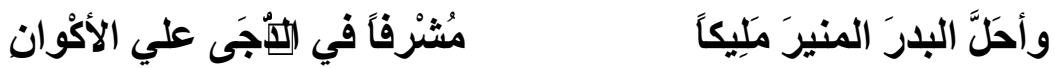

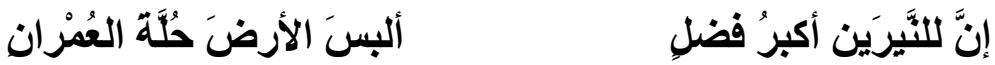

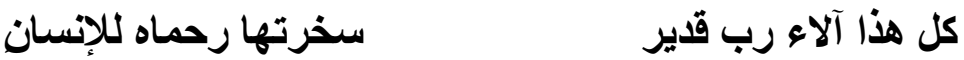

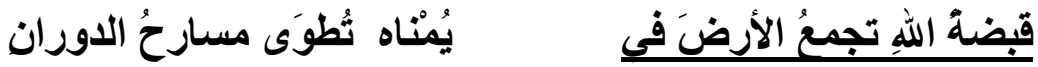

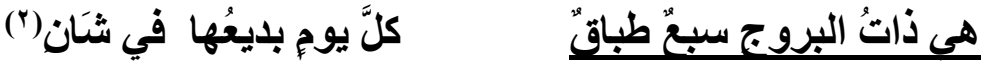

فالثـاعر كما نرى قد اقتبس الحديث عن مظهر من مظاهر قدرة الله

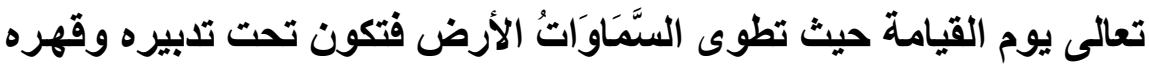

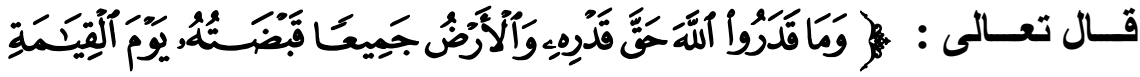

(َ)

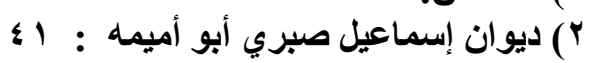

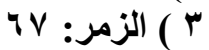


فالآيـة الكريمـة كمـا قـال مجاهد: نزلت في قريش وعن ابن عبساس

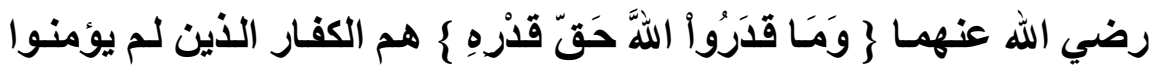

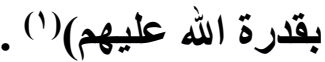

وهى تمثيل لعظمة الله تعالى وكمال قدرتهـ بحسال من تنـاول الأرض و

أخذها في قبضته ومن طوي السـماوات فمحا رسومها وطمس أفلاكها ، وآثُر النظم الكريم الإخبـار عن الأرض بالمصدر(قبْضْنَتُهُه) وهـى استعارة تصريحيه للالالة على تمام التمكن وإحكام التصرف مـن المقبوض،كمـا آثر الإخبار عن انكدار نجوم السـماء وفسـاد تركيبها واختلال نظامهـا بـالطي استعارة مكنية وخص اليمين وهى كنايـة عن القدرة لكونها أشرف اليدين وأقواهمـا والتي لا غنـاء للأخرى دونهـا ، وهذه النكـات البلاغيـة وغيرهـا دعت الثاعر إلى الإفادة منها وتوظيفها بهذا الاقتباس القرآني .

وبعد ثلاثمائة وخمسين بيتا جال فيها الثاعر في مجالات عدة يعود للحـديث عـن السَّسمَاوَاتِ وَالأرْض مبينـا مقـدار خضـوعهما واستسـلامهما وانقياد هما لقرة الله تعالى اختيارًا أو إجباراً فيقول :

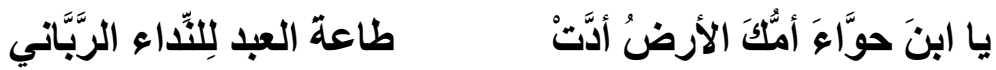

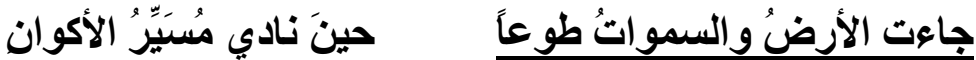

تذكرُ اللهَ خيفة كلّ آن

وَحَبَتُها بِيْضِِها النَّوراني
سابحاتُ الأفَلاكِ في كلِّ بُرْج سنَيَّرتها يدُ العنايةِِِ لُطفاً 


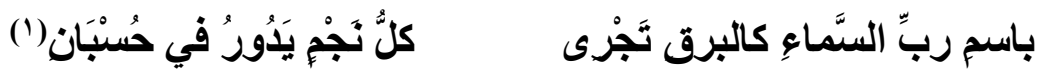
فالشَاعر اقتبس مشهد استجابة السَّمَاوَاتِ وَالأرْض وامتثالههــا لأمر

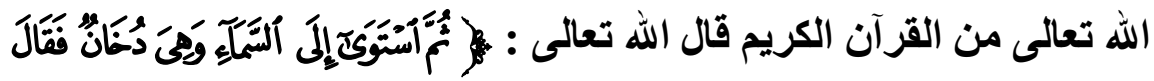

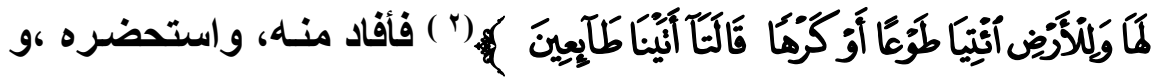
عبر عنه بجملـة خبريـة أحسن الشـاعر توظيفهـا ؛ لتــدمج في القصيلة ، وتتلاءم مع دعوته لابن آدم بالخضوع والانقياد .

ثـم يعود الثـاعر للحديث عن قدرة الله تعسالى وإبداعـه في خلق

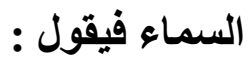

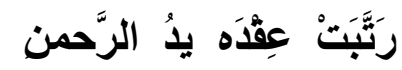

قر جَبَاها باللطفِ والإحسان معجزٌ وصفُه قوى 'العِرْقان ومحالٌ إدراكُه بالعيان والسموات شادها من دخان جَلَّ شأنَاً وعزةَ خَيرُ بان(")

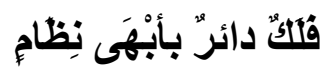
شُاكراتُّ أجر امُهه فضلَ ربٍ صانعٌ مباعُ عليمٌ حكيمٌ حاضرّ" شاهدُ سميعٌ بصير" بدأ الخلقَ والعوالمَ ذرَّاً

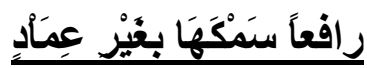

1) ديوان إسماعيل صبري أبو أميمه : 1)

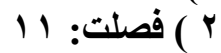

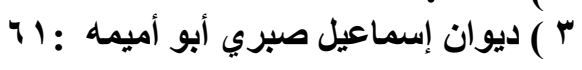


فالثـاعر قد اقتبس خلق السماوات ورفعها وتشييدها من دخان من

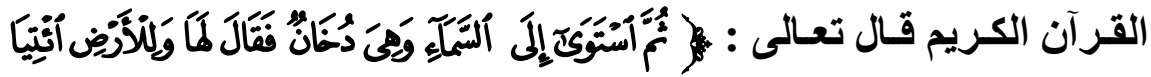

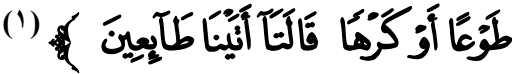

فأفاد واستلهم هذه الحقيقة القرآنية وصاغها وضمنها في شعره .

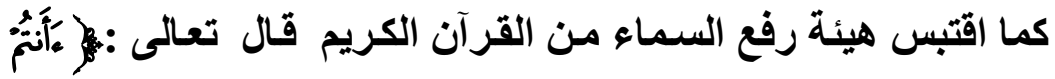

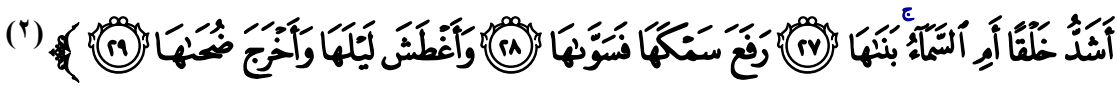

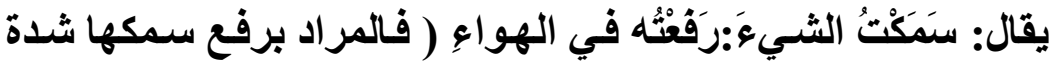

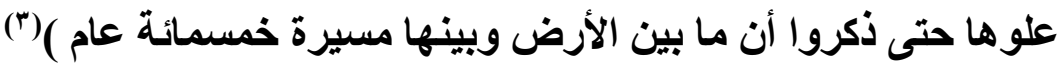

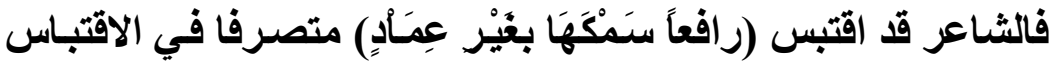
فجاء باسم الفاعل (رافعاً) وزاد احتراسـا (بغَيْر عِمَاْدِ) وهو مـا لـم يتطرق إليـه النظم الكريم فى هذا المـوطن بينمـا بـا تـأثره واضـحا بـآيتي الرعد

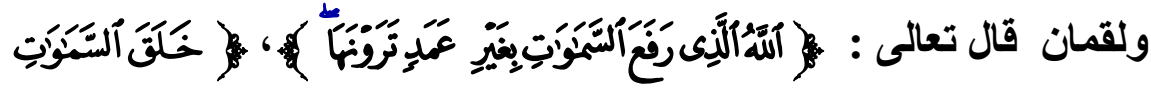

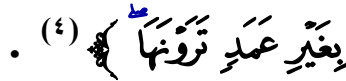

$* * * * * * * * * * * * * * * * *$

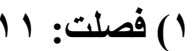

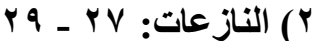

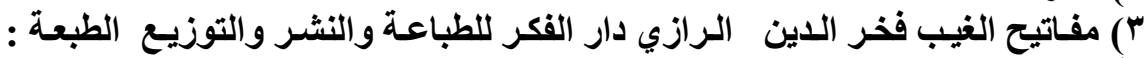

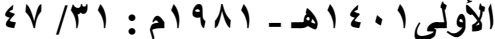

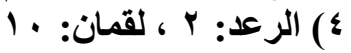




\section{المبحث الثالث}

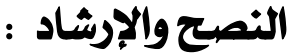

القرآن الكريم كتاب الإسلام الخالد ، و دستوره الجامع ، جاء لهايـة

الخلق و إخراجهم من الظلمات إلى النور بإرشـادهم وتوجيههم إلى مـا فيهل

صلاحهم ، وقد تأثثر الثـاعر بلغة القرآن الكريم فضَمَّنَ الكثير من شعره

نصحاً وإرشاداً قرآنياً مقتبساً منه اقتباساً تطابقت ألفاظه في الكثير منه ه

فبعد ثنائه على أشرف الخلق سيانا محمد ـصلى الله عليه وسلمفهو :

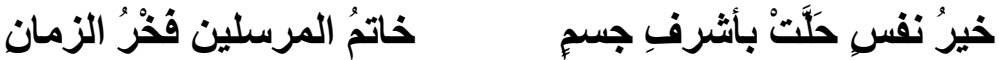

أحمدُ المجتبى شفيعُ البرايا هادمُ الكفر شائدُ الإيمان

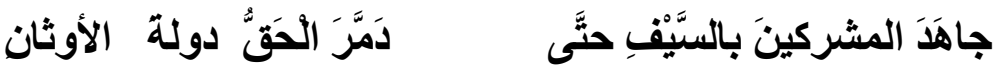

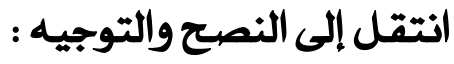

وادكُروا اللهَ خِيْفة كلِّ آن

أيُهَها النَّاسُ امنوا وأطِيْعُوا

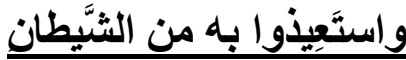

سبِّحوه مستففرين ويُوبُوا

طهروا النفسَ باجتناب المَعَاصبي واستَزيدوا هلياً مِنَ القرآن

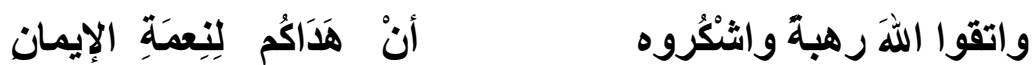

واستقيموا فهو الرقيبُ عليكم ومحالٌ أنْ يختفي عنة جَاني 


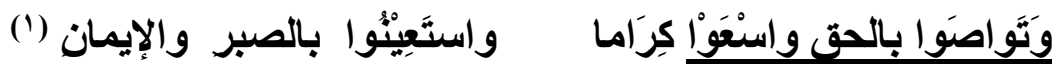

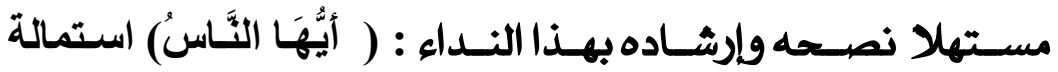
للمتلقين ، وجذبا لانتباههم ، ليقع النصح موقع القبول والرضسا ، داعياً إلى الإيمـان بـالله وطاعته و ذكره والاستعاذة بـه من الشيطان والاستعانة بالصبر إلى آخر ما ذكر من نصـائح كلها قـ استقاها الشـاعر من القرآن

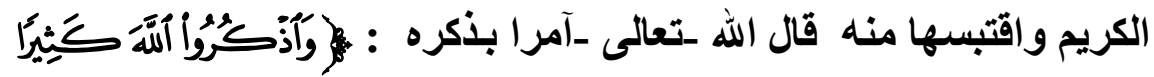

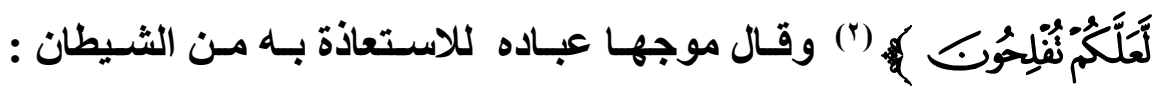

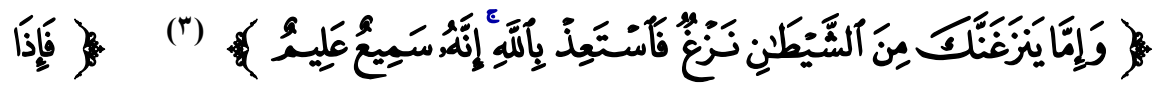

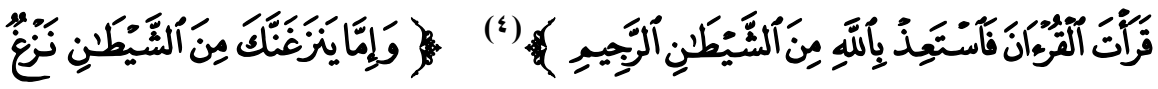

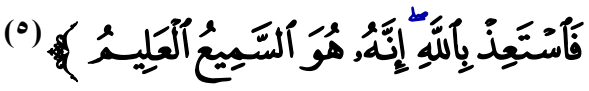

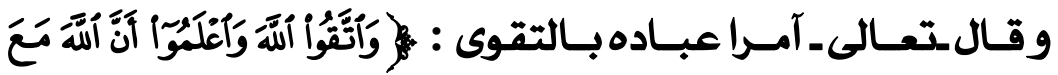

(1) آلْدَنَفَيَينَ

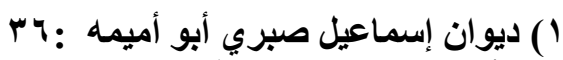

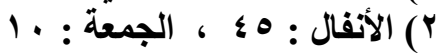

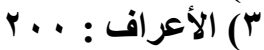

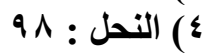

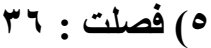

( 19 البقرة : 19 
كما قال تعالى منـــرا على هؤلاء الأعراب الذين امتنوا على

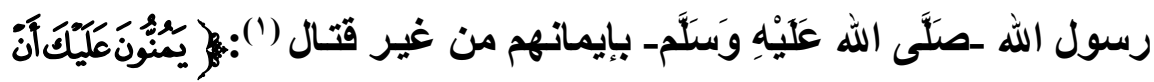

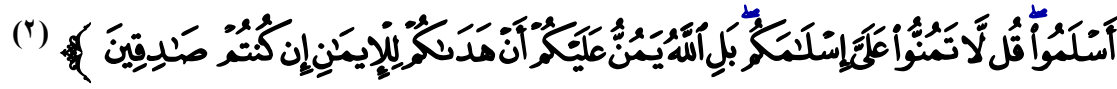

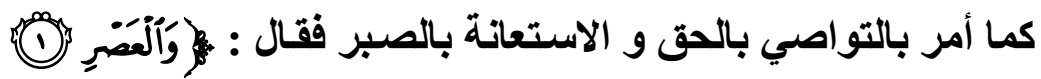

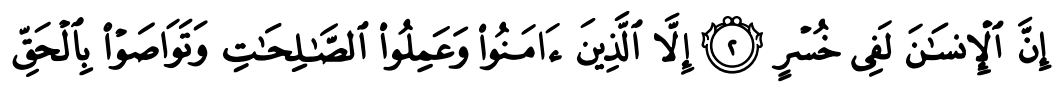

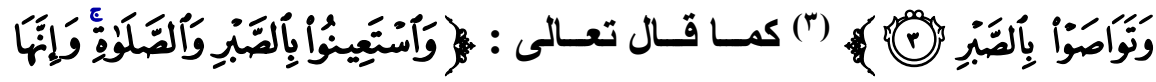

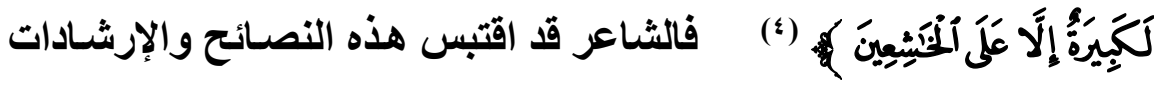
القر آنيـة وضمنها شعره اقتباسـا تطابقت ألفاظه تـارة وتصرف في أكثره

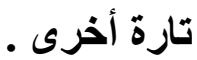

وهذا الاقتباس الأخير : (واستعينوا بالصبر ) قد تكرر أكثر من مرة يسبقه إيقاظ ولفتُ انتباهِ بالنداء : (يـا أيها الناس )والذي كثر في القرآن لأن فيه كما قال الزمخشري وغيره أوجها من التأكيد وأسبابا من المبالغة

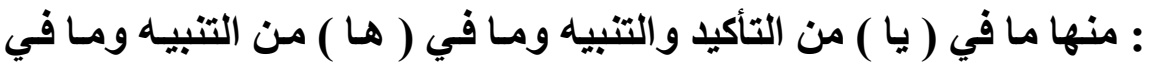

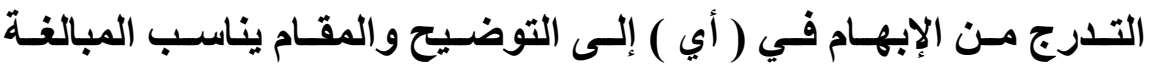

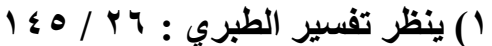

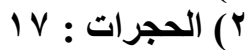

$$
\begin{aligned}
& \text { r } \\
& \text { ع) البقرة : العصر : }
\end{aligned}
$$


والتأكيد، لأن كل ما نادى له عباده من أوامره ونواهيه وعظاته وزواجره ، ووعده ووعيده ومـن اقتصـاص أخبـار الأمـم الماضية وغير ذلك ، وممـا أنطق الله بـه كتابـه أمسور عظـام وخطوب جسـام ومعسان واجب عليهم أن يتيقظو الها ويميلوا بقلوبهم وبصائر هم إليها وهم غافلون ، فاقتضى الحسال

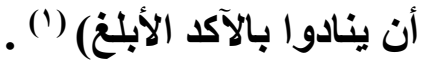

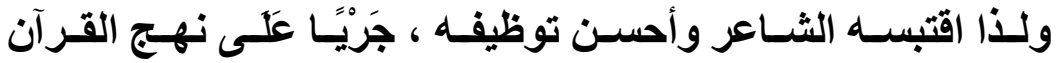

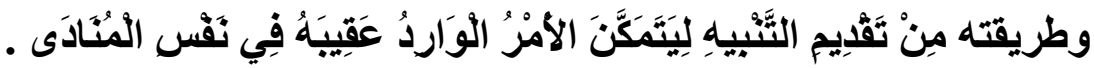

وبعد النداء يدعوهم إلى ترك اللهو وصنع الخير مستعينين بالصبر في كل خطب ، فهودواء للنفس والفؤاد فيقول :

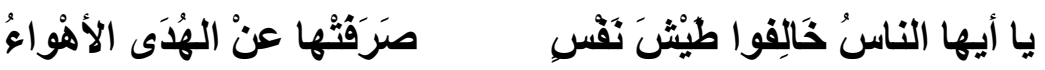

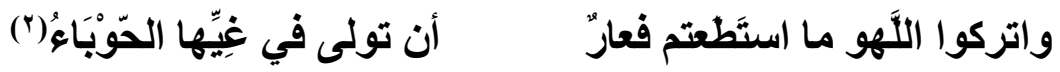

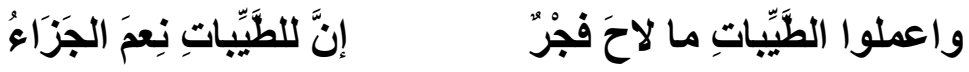

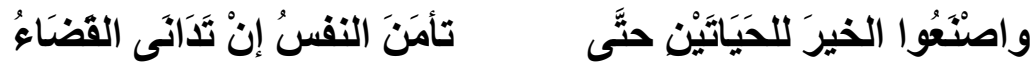

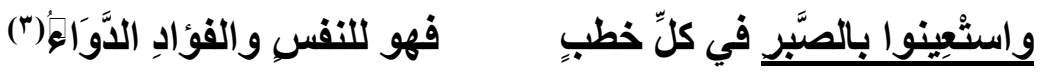

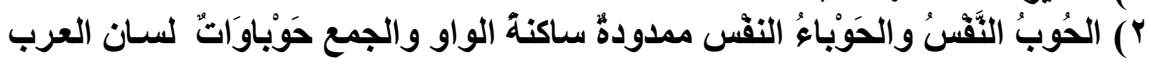

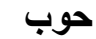

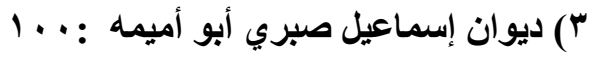




$$
\text { كما تكرر في قوله : }
$$

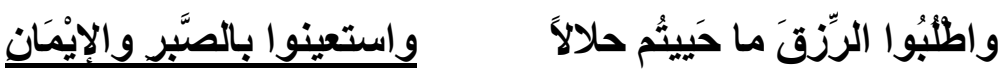

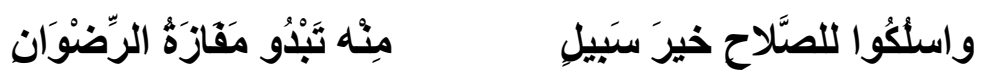

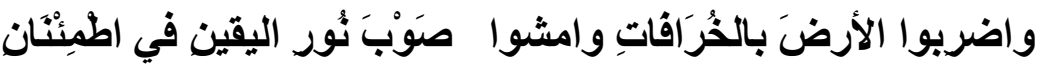

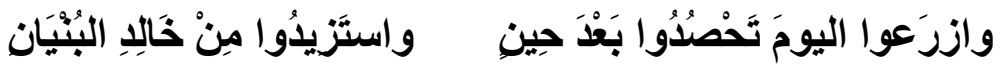

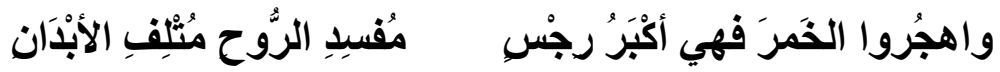

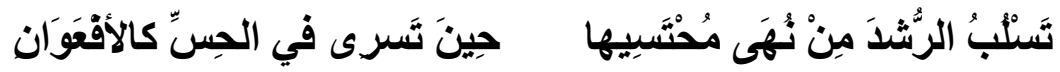

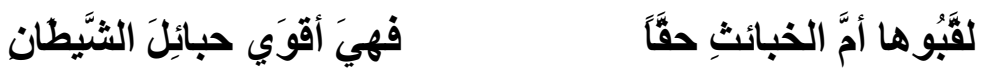

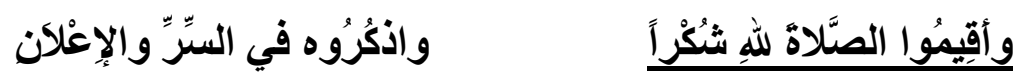

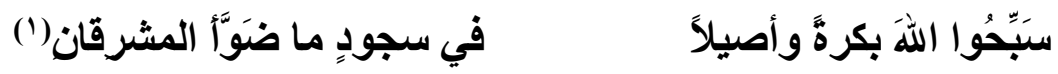

كما جاء قولهه : (وَأقِيمُوا الصَّلاة ) في قوله :

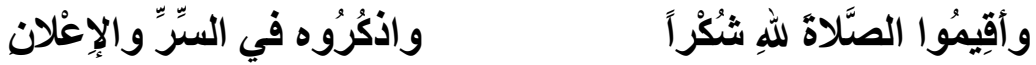

مقتبساً من قول الله تعالى : ( وَأقِيمُوا الصَّلاة ) والمراد بإقامتها : المداومة على أدائها على الوجه الأكمل ،وعبر عن ذلك بالإقامـة لأن القيام

( ) ل ديوان إسماعيل صبري أبو أميمه : 
بعض أركانها فاستعير للعنايـة بها والمواظبة على أدائها ، استعارة تبعية (تنبيهاً على أنَّ المقصود منها توفية شر ائطها لا الإتيان بهيئاتها) (' . وقد وفق الشـاعر في اقتباسـه مسـتفيدا بمــا اشـتمل عليـه الـنظم الكريم من لطائف بيانيتً. كما جاء قوله :

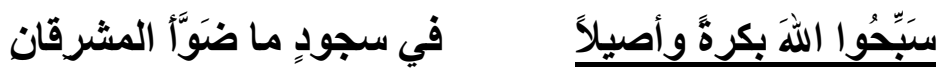

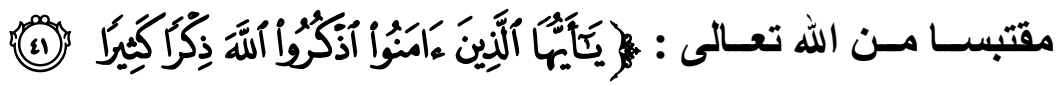

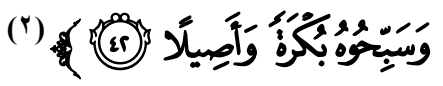

أي ( أول التهـار وآخـره ، وتخصيصـهما بالـذكر ( بُكْرَةَ وَأصِِيلا ) للالالة على فضلهما على سائر الأوقات ، لكونهمـا مشهودين بملائكة الليل

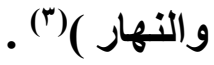

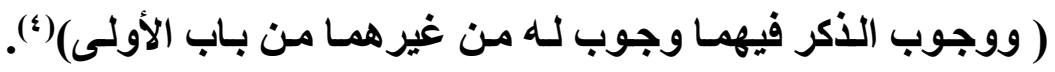
وهذا مـا أراده الثـاعر مـن لـزوم الــكر والتسـبيح ودوامـه ؛ فكـان هـذا

(1) بصائر ذوى التمييز في لطائف الكتاب العزيز الفيروزابادى محمد على النجار دار

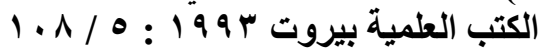

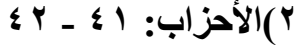

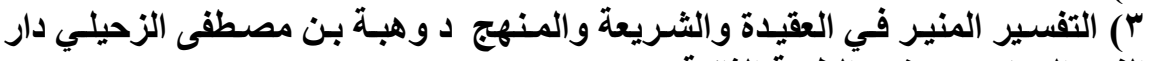

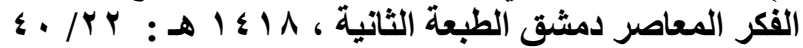

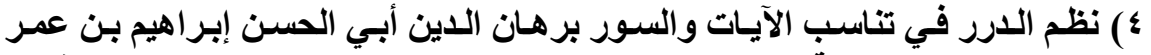

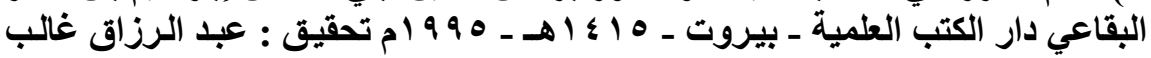


الاقتباس الذي لـم يتدخل فيـه الثـاعر إلا باستبدال الضمير في (وَسَبِّحُوهُ) بلفظ الجلالة .

وتتولى نصائح الشـاعرو إرشـاداته المقتبسـتمـن القـرآن الكـريم

حيـ جـاء تحذيره مـن الاغترار باللدنيا ونسيان المـوت مبينـا أن الآجَالَ

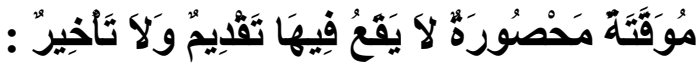

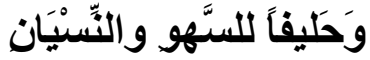

طائرَ اللُبِّ عَارقاً في الأمَانِي

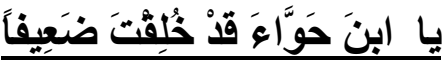

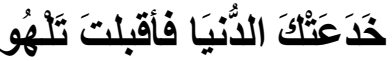

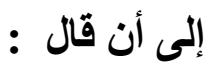

فيها يُجْزَى المطيعُ بالإحسان قُتْرَهُ الأرض في الحياةِ اختبارٌ في نعيم أو في لظى التّيران وبدار البقاء تَخْلُُْ نفسُ إذذ ينادِى الحِمَامُ آنَ أوانِي تُنْقلُ التفسُ من حياةِ لأخرى

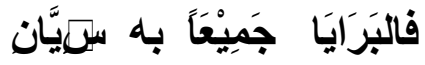
إنَّهَه الموتُ لمْ يَََعْ أبيَّ حي وإذا حُمَّ فَالمقدَّرُ دَان فَإذا جَاءَ أمرُهْ لِمْ ليُوَخِّرّ

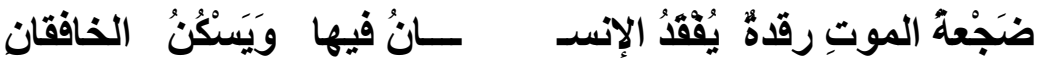
وهو كأسُ لا بُدَّ للظمآن(') فهو بابٌ يجتازه كلُّ حَي 


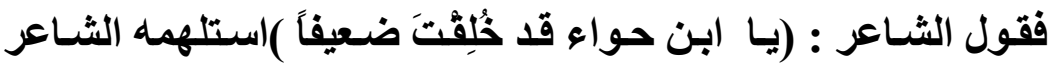

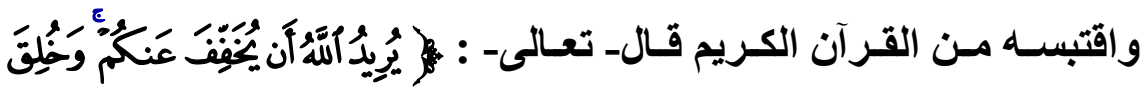

\section{(1) آلإنسَنَنُ ضَعِيفًا}

كما جاء حديثه عن الموت : (فَإِا جَاءَ أمرُه لُْ يُوَفَّرْ) مقتبسـا من

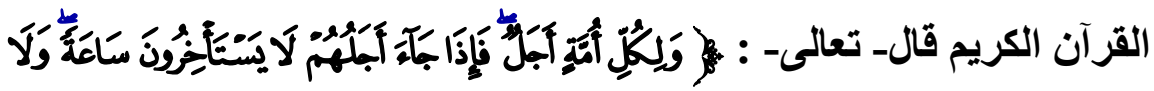

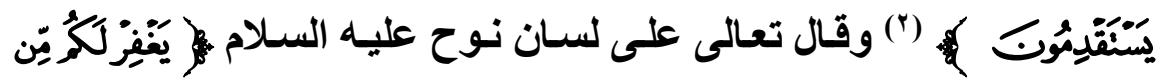

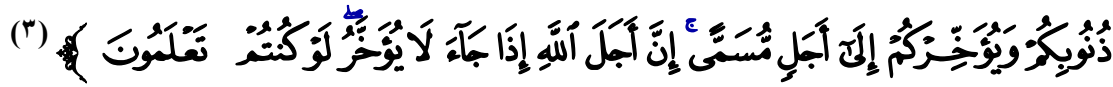

وقد تكرر التحذير من الموت كثيراً في شعره فبعد ثنائه على خاتم النبيين و المرسلين سيدنا محمد ـصلى الله عليه وسلم -حيث قال :

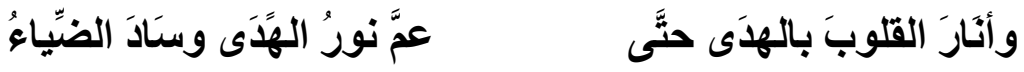

$$
\begin{aligned}
& \text { وأعزَّ الإسنْلامَ رغَمَ أنثُوْفِ }
\end{aligned}
$$

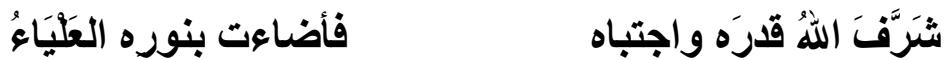

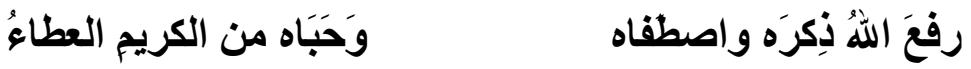




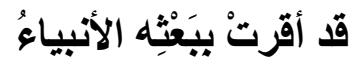

خَاتَمُ الرسنْ نُورُها الوَضَّاءُ

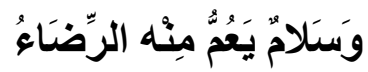

سيدُ العالمين خيرٌ بشير

أولُ الخلق رتبة ومقاماً

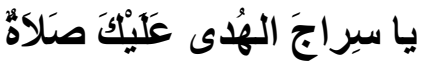

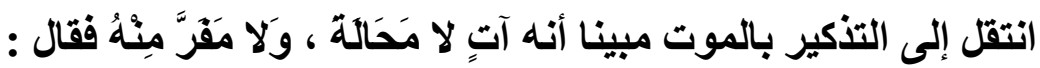
تَِّ يقينا متى دعاها القناءُ

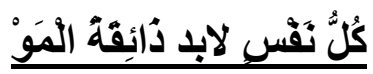

ونفادٌ لما أرادَ القضاعُ(1)

سنة اللهِ في جميع البرايا

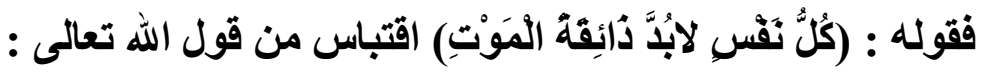

\section{(「)}

فالكل متجرع كأس المنون ،و قد آثر النظم الكريم التعبير عن حلول الأجـل بالـذوق على سـبيل الاسـتعارة المكنيـة تثـبيها للمـوت عنـــ إقبالـه الرهيب بشـيء كريـه الطعم مـر المـاق ( والعدول عن" تذذوق المـوت"

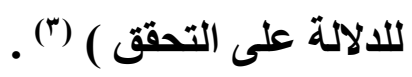

كمـا أسـنـ ذوق المـوت إلى النفس ، ولـم يسـنده إلى الثـخص؛ لأن النفس روح ، والثخص جزعان جسم ونفس ، وإن النفس تبقى بعد مفارقة الجسم ، فهي التي تذوق الموت ، كمـا ذاقت الحيـاة الدنيا ، فإسناد الذوق

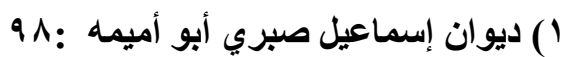

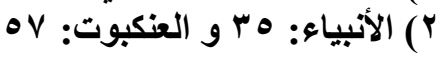

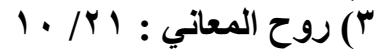


إليها لأنها باقية ، وقد تغيرت حياتها من حال إلى حال ، فبعد أن كانت في غلاف من جسم من الطين ، قد تجردت أبداً منـه حتى تلتقى بـه يوم البعث

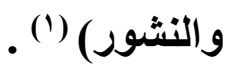

وقد أفاد الثاعر من الدلالات البيانية التي اشتمل عليها النص الكريم

بهذا الاقتباس الذي لم يتصرف فيه الثـاعر سوى في زيادة كلمة (لابُدَّ)

بين المسند و المسند إليه لتأكيد تلك الحقيقة ، ولاستقامة الوزن الثعري ـ لهائ

كما تكرر تحذيره من الموت :

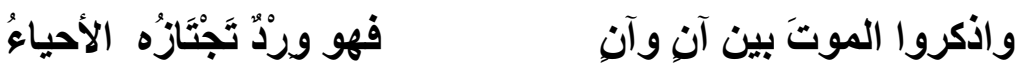

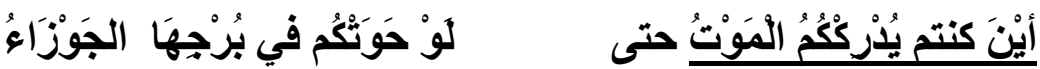

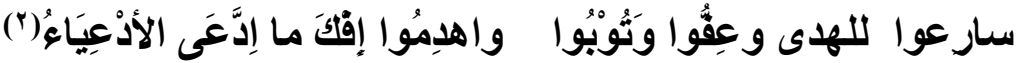

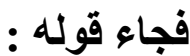

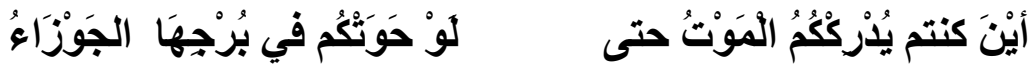

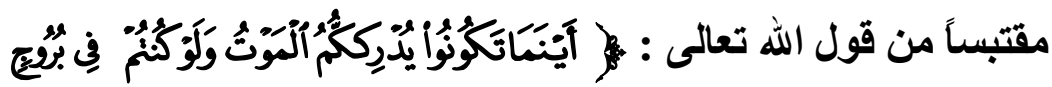

(")

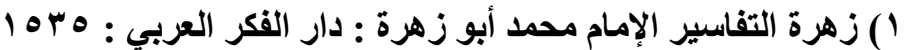

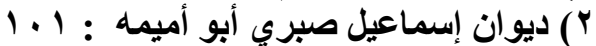

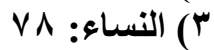


والمتأمل في نظم هذه الآية الكريمة يجد أنها اشتملت على جملة من النكات البلاغيـة تكاتفت للوفاء بحق المقـام الذي وردت فيه : مقام الحث

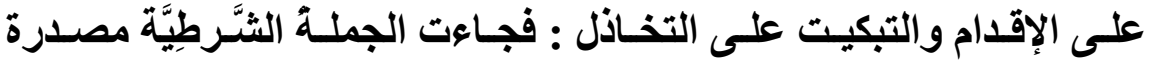
ب(أيْنَمَا)لاستغراق الأمكنة وإيثار لفظ الإدراك للإثعار بأنهم في الهرب منهـ

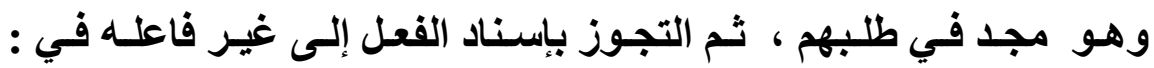

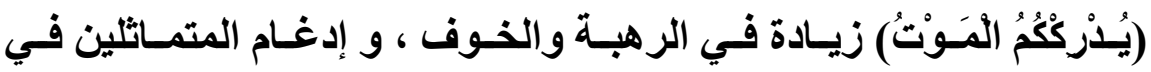
(ياركَم) والأي يوحي بنقص أحرف الكلمة مما يال على سرعة الموت في إدراك مـن قضسى عليـه المـوت (')،ثـم إيثـار البـروج الموصسوفة بالمشـيدة (لأنها غاية البشر في التحصن والمنعة، فمثل الله لهم بها)(؟) . وهـا مـا حرص الشــاعر على اقتباسـه والإفـادة منـه متصـرفا في الاقتباس على نحو ما نرى مستببلا البروج المشيدة بالجوزاء بما تحمل من إيقاع موسيقي بليع استكمالا للصورة وحفاظا على نست الأبيات ونظمها . كما اقتفى خطا القرآن في الدعوة إلى تقوى اللهـ تعالى ـ فهي خير

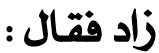

أن من عَفَّ عاش في إطمِينْنان يا ابن حواء دع غُرورَّك واعلم وتباعد عن حماةِ العدوان خالفِ النفسَ واجتنبْ كُلَّ شر وافعل الخيرَ مـا استطعتَ وأصلِحْ وتسابقُ في البر والإحسان 


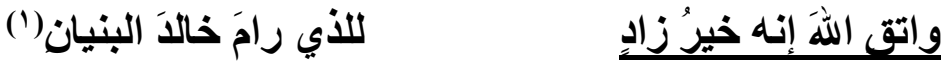

فقوله : واتق الله إنه خير زاد استلهمه الشـاعر واقتبسـه من قول

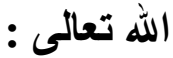

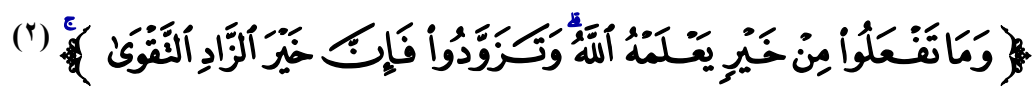

الزاد ما يتخذ من الطعام ، والتزود منـه حقيقي ومنـه مجـازى : ذلكـ

أن الإنسان له سفران : سفر في الانيا وسفر من الدنيا : فالسفر في الدنيا لا بد له من زاد وهو الطعام والثراب والمركب والمـال ، والسفر من الدنيا لا بـد لـه أيضـا من زاد وهو معرفة الله ومحبته ، وهذا الزاد خيز من زاد المسافر في الانيا ؛ لأنه يقي المرعَ من عذابٍ أبدي” ("ان

وقد جمعت الآية ببين زاد الدنيا وزاد الآخرة : فعن قتادة : إن ناسـا من أهل اليمن كانوا يحجون ويسافرون، ولا يتزودون، فأمرهم الله بالنفقة والزاد في سبيل الله، ثم أنبأهم أن خير الزاد التقوى)(؛).

أو أن المراد زاد الآخرة وعليه فـالتزود مستعار للاستكثتار من فعل الخير استعداداً ليوم الجزاء شبه بإعداد المسـافر الزاد لسفره بنـاء على إطلاق اسم السفر والرحيل على الموت) (0)

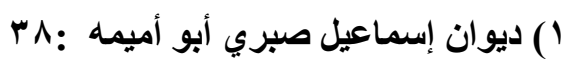
ا ب البقرة:

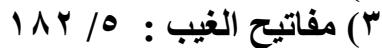

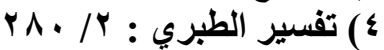

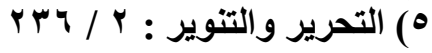


ولعل المراد بالزاد هو زاد الآخرة والدليل عليه قولـه بعد ذلك ج قِإنَّ

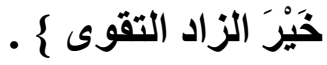

وقد استلهم الشاعر دلالة هذه الآية ، وأجاد في الاقتباس ، بل و في توظيف هذه الصورة البيانية توظيفا جيدا خدمة لغرضه .

كما تكرر هـذا الاقتبـاس وبصـورة أخـرى تنبـئ عـن تمكـن

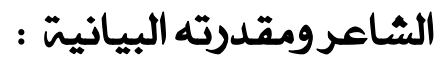

شاغلتها وستَاوسُ الثشَّيَّان

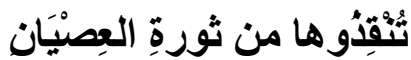

تَتَّوَارَى عن مُعْزَعَاتِ الأماني

تَّكر اللهَ خِيفة كلّ آن

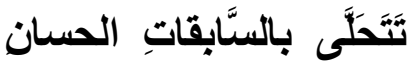

فيه تَبْقَى سنعِيدةً في أمَان

خيرُ زادٍ للمَنَهُ النَّفَنَانِي

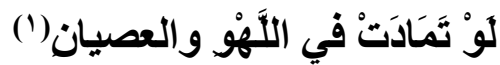

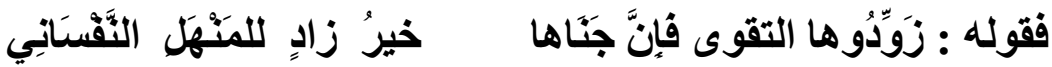

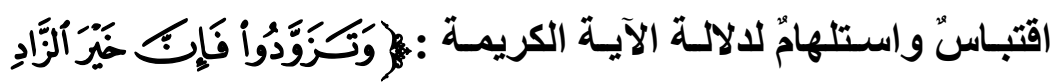
حَاريُوها بالطَيِّاتِ عَسَاها
أيهُها النَّاسُ خالِفوا غيَّ نفس طهرِوها من الرَّذيلةِة حتى حدَرُوها عَيْنَ الرَّقَيبِ لكي عُوَّدُوها على الفضيلةِ حتى ألبسُوها من طاعةِ اللهِ نوراً زَرَدِدُوها التقوى قَإنَّ جنَّاها ذَكُّروُها أنَّ الحِسَابَ عَبِير"

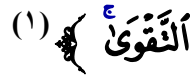
IV: ديوان إسماعيل صبري أبو أميمه 
وخلال تأملـه في هذا الكون الفسيح ومـا أبدع الله فيـه من عجائب الخلق جاء تحذير ه من وقفة الحساب وما يستتبعه من سعادة وشقاء حيث

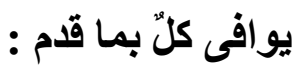

منه صِيْعْتَنْ هَيَاكلُ الأبدان تُم يَبْلى على مرِّ الزَّمان

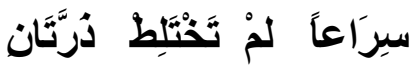
ما تَنَّاءَى عِلِمَاً عَنْ الألدَهَان قِبْلَ خَلق الأرَْْاح و الجُسنمَان يَبْدُ للأُور هيكلُ الإنسنَان قَقَرَتْهُه إرادةُ الرَّحمَنْ مِنْ سعيدٍ ومِنْ شَقِي قِضَاءً

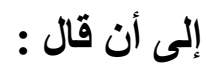

في إمَاج مفصَّل التبّيان (r)

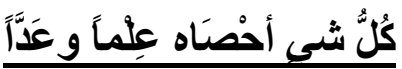

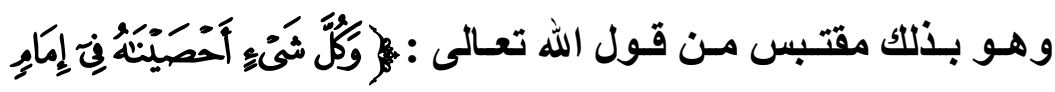

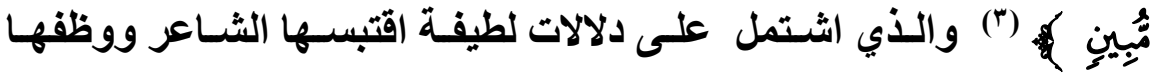


وأفاد منها فقد اشتمل القول الكريم على ما يفيد الإحاطة والعموم لمـا قدموا

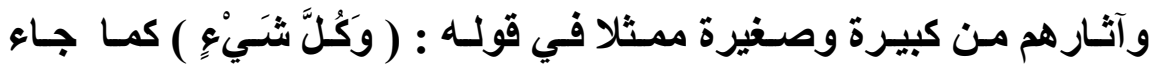
الإحصـاء كنايـة عـن المجـازاة : أي ونحصـي ، فعبر عـن إحاطـة علمـهـ بأعمالهم بالكتابة التي تضبط بها الأشياء ،كما أطلق الإمام على الكتاب لأن الكتاب يتبع ما فيه من الأخبار والثروط)('). وهذا ما حرص الثـاعر على اقتباسه مع التصرف في الاقتباس حيث أسند الفعل( أحصى ) لضمير الغيبة ثُم أتبعـه بـالتمييز ( علمـاً وعداً ) واسـتبدل الوصف ( مُبين) ب(مفصل التبيان )لاستقامةِ الوزن الثعري.

كما جاء تحذيره من الشـيطان وكيـده في ختـام تناولـه لقصــة المسيح عليه السلام وما حدث فيها من كذب وإفلك وتضليلب حيث :

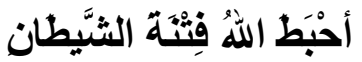
دَبَّرَ الآثِثِوُنَ كيداً ولكنْ

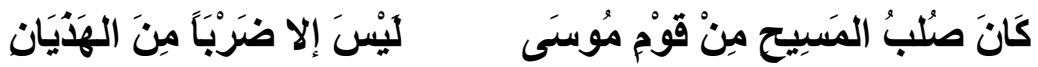

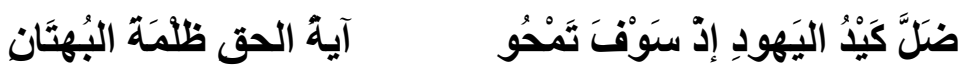
حِينَ قَامُوا بِعَرْضِِهِ للعَيَان صَوَّرَ اللهُ للمَسيح شَبِيهاً إلى أن قال وَهوَ يَذْعو للشَّرَ والعِصِيَان

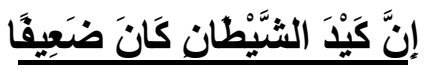

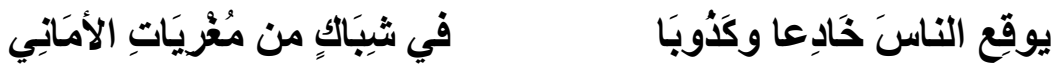

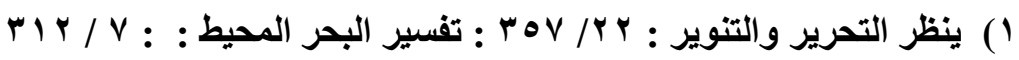




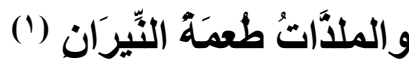

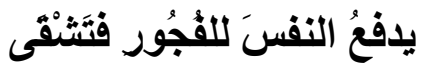

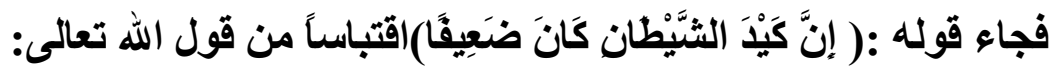

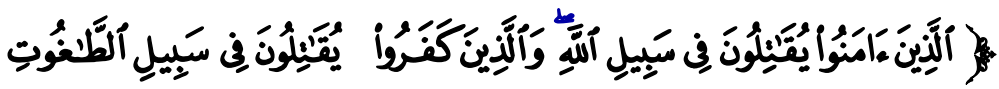

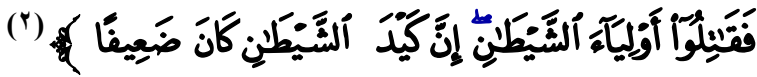

وقد اشتمل النظم الكريم على حقيقة مؤكدة اقتبسـها الشـاعر و نقلها

دون زيادة أو نقصان ، وأفاد منهـا وأحسن توظيفهـا خدمـة وتجسيدا لمقـام

التحذير من كيد الثيطان وغوايته .

$* * * * * * * * * * * * * * *$

(1) إيوان إسماعيل صبري أبو أميمه :

VV V V T أنساء 


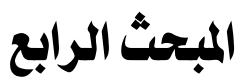

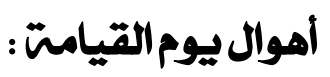

صور القرآن الكريم العديد من مشاهد يوم القيامة وعرضها عرضاً حياً ناطقاً ، موحياً و مؤثراً يبعث على الرهبة في النفوس ويثعر بالهول والخوف الثديد الذي يحل بالناس في ذلك اليوم.

وقد تناول الثـاعر بعض هذه المشاهد وصورها تصويرا بليعا متأثرا

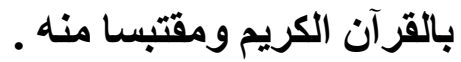

فبعد ثنائه على الذات العليتّ أحسن التخلص إلى الحديث عن

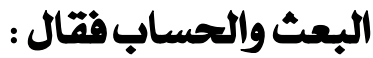

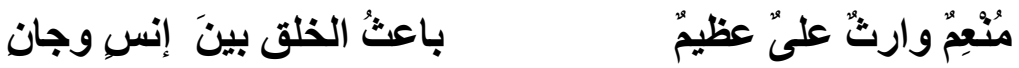

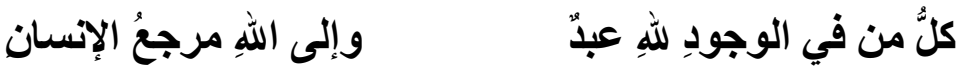

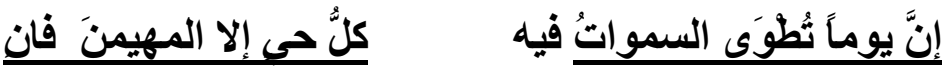

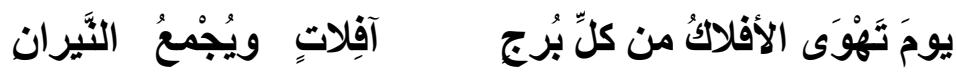

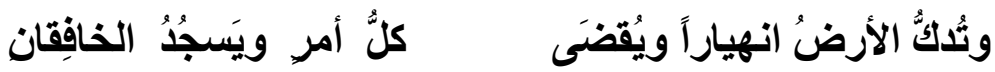


تَنْسفِ الأرضنَ بين قاص

صَيْحة تجعلُ الرواسلي عِهْنَاً

ودان(')

فمن البعث والنشور إلى الحديث عن القيامة وأهوالها حيث تطوى

السموات وتدك الأرض وتهوى الأفلاك من كل برج آفلات ويجمع النيران وتقنى الخلائق ويقضى كل أمر ،

و كل هذه الأحداث المفجعة وغيرها اقتبسها الشاعر من القرآن الكريم فقوله : إن يومـا تطوى السموات فيه اقتبسه من قول الله ـ تعالى- :

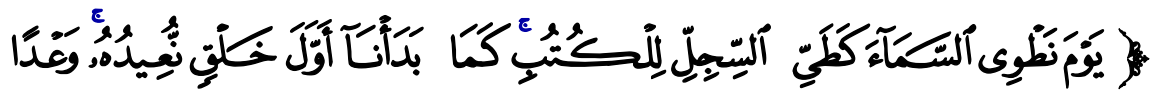

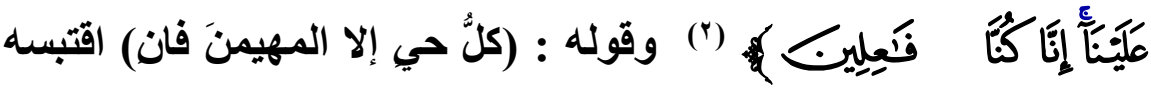

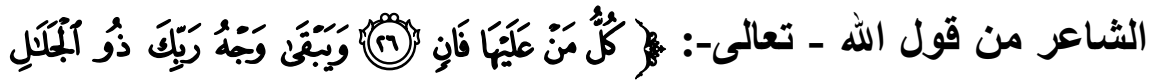

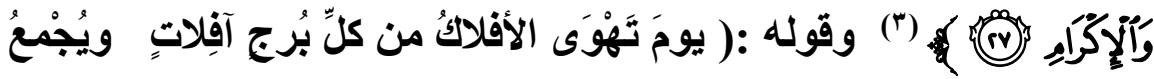

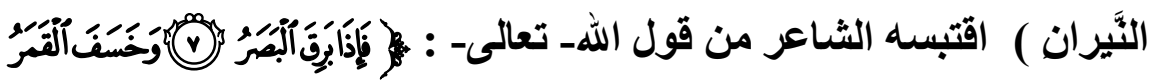

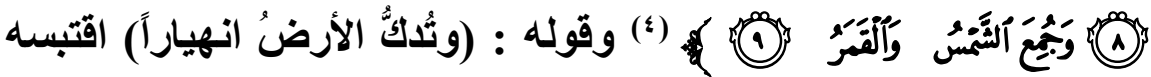

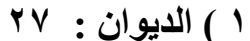

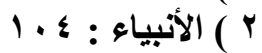

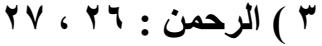

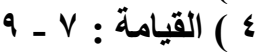




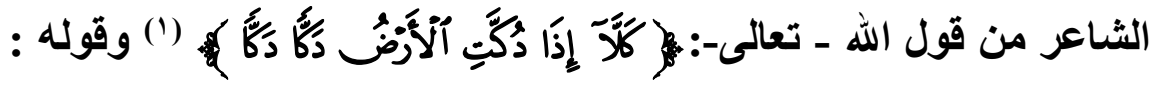
(صَيْحة تجعلُ الرواسلي عِهْنَا) اقتبسه الثَاعر من قول الله ـ تعالى- :

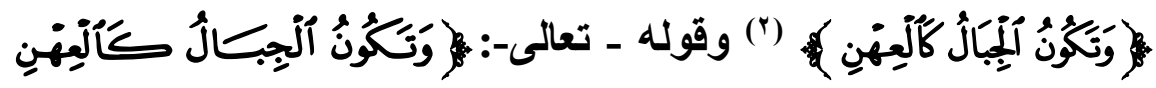

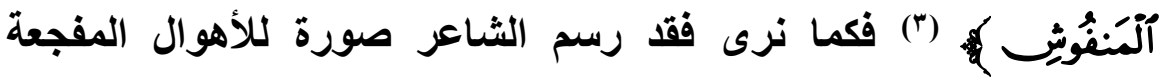
والحوادث المحزنة التي تقع في يوم القيامة جمع عناصرها من آيات كثيرة فأعاد تثكيلها، و ألف بينها وأجاد سبكها وأحسن صياغتها صياغة شعرية ،لا تخطيء الأذن عند سماعها أنها اقتباس قرآني أفاد الثاعر قدر استطاعته مما تضمنته النصوص الكريمة من نكات بلاغية وفاء بمقام التهويل والتخويف فقد حرص الثاعر على استبقاء المفردات القرآنية و

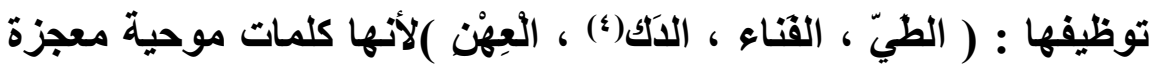
في مكانها لا يقوم مقامها غيرها : فقد آثر النظم الطيّ لأن الطي يعطي

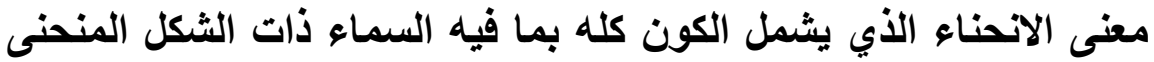
المظلق ، فلا خطوط مستقيمة في الكون بل كله مندن وهذا ما أكلته أحلث

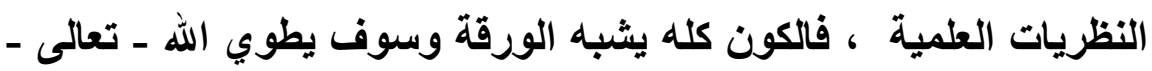
هذه الورقة يوم القيامة، ويعود الخلق كما بدأ ) (o) .

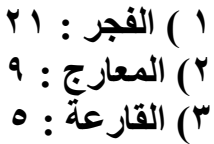

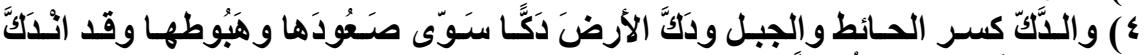

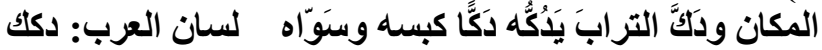

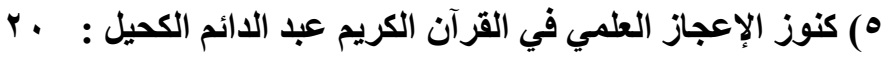


هذا ولم يتعرض الثاعر لا من قريب ولا من بعيد لهذا التشبيه الذي دل على سهولة الأمر ويسره على الله ـتعالى -حيث يطوي السماوات على عظمها واتساعها ـ كطي السجل على ما فيه من المكتوب فتنثر نجومها، ويكور شمسها وقمرها.

كما آثر النظم لفظ القناء بعموم مدلوله للإشثارة إلى عموم هذا الحكم وشمول الإهلاك كل الخلائق وكذا لفظ (الآَك) للإشارة إلى قوة الهـم والتفرق والإبلاغ في تأثيره بأن صارت الأرض في غاية الاستواء ، كما

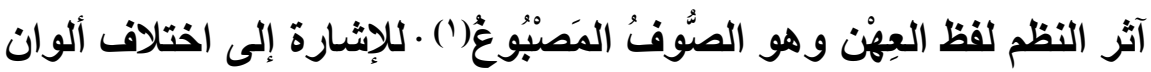
الجبال التي تفرقت بعد اجتماعها ولاتت بعد شدتها فتطايرت مختلفة الألوان فمنها الجدد البيض والحمر و الغزابيب السود وهذا ما حرص الثـاعر على الإبقاء عليه وتوظيفه والإفادة منه .

كما حرص الثـاعر على بناء الفعل(يجمع وتدك) لما لم يسم فاعله كما وردا في النظم الكريم وان اختلفا في زمانهما ( جُمعَعَ و دُكَّتِ ) لينصنبّ الاهتمام علي هذا المشهر الغيبي بخفاياه ودقائقه زيادة في بث الفزع والرعب في قلوب المتلقين لاسيما و أن فاعلها هو الله ـتعالى-إذ لا يقدر علي ذلك غيره .

وكما صور الثاعر قوة الصيحة و أثرها على الأرض والجبال الرواسي متأثرا بالقرآن ومقتبسا منه صور أثرها على الإنسان في صورة قر آنية تظهر مقار الهلع الأي يصيب الناس من جراء هذه الصيحة : 


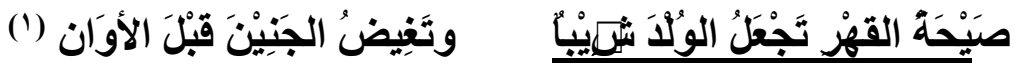

فالثاعر قد اقتبس هذه الصورة المفجعة من القرآن الكريم قال الله ـ

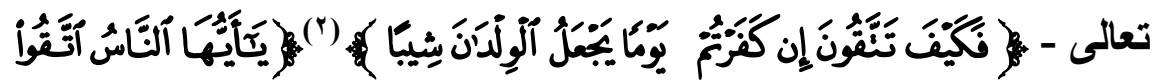

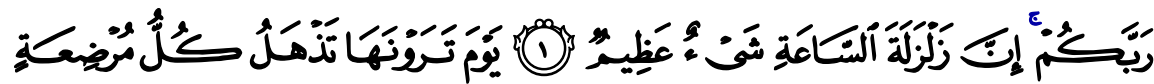

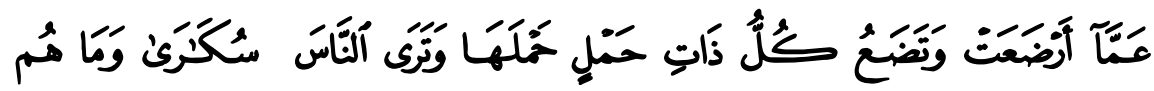

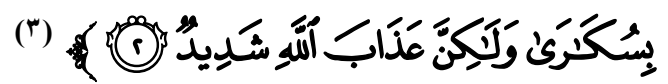

فالآيتان الكريمتان تصوران جانبا من الأهوال والأحزان التي تقع في هذا اليوم المهيب: فالآية الأولى بالغت في وصف هول هذا اليوم وطوله وأنه يوم يجعل الولان شيبا ، إذ لما كان الثيب من لوازم كثرة الههوم والأحزان جعلوه كناية عن الثدة والهول ، أو أن الأطفال لطول هذا اليوم فهم يبلغون فيه سن الثيخوخة والشيب أما الأخرى فهي تصور مشهد الهول والفزع الأي ينسى الوالدة رضيعَها وشُشْط الحوامل ما في بطونها قبل ميعاد وضعه ،وتذهب بعقول الناس و إدراكهم. وهذا ما اقتبسه الشاعر وأفاد منه بل إن الثاعر كعادته يكشف عن سعة اطلاعه و إلمامه بألفاظ القرآن الكريم حيث اختار (تغيض) قال -

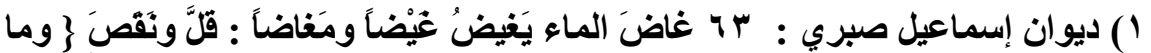

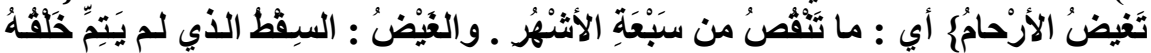

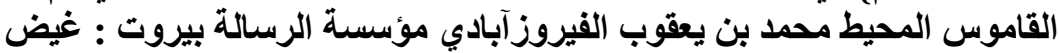

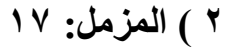

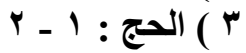




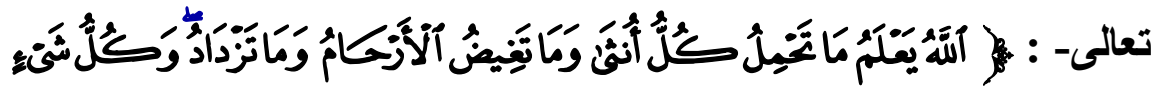

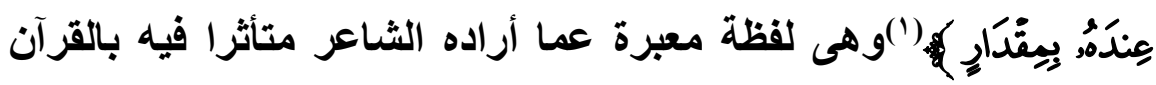
الكريم إذ المراد بغيض الأرحام : ( السقط الناقص ) وما تزداد : ( الولا

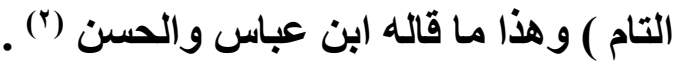
وبعد تناوله لقضية البعث والحكمة منه عاد الثاعر للحديث عن

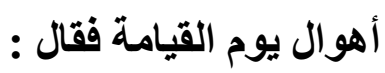

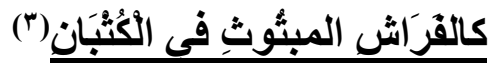

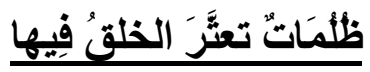

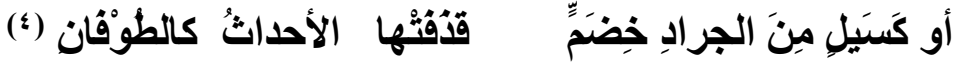
فالثاعر يصور خروج الناس من القبور، وانتثارهم في ذلك اليوم

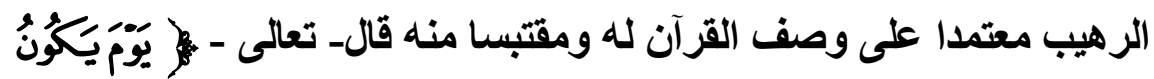

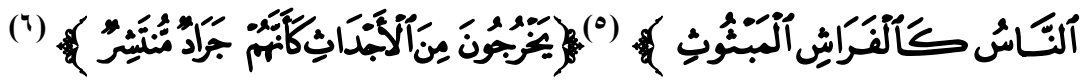

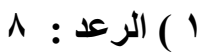

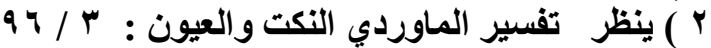

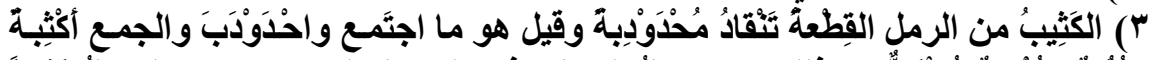

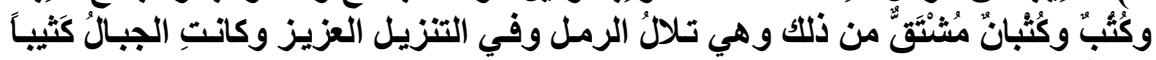

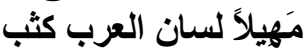

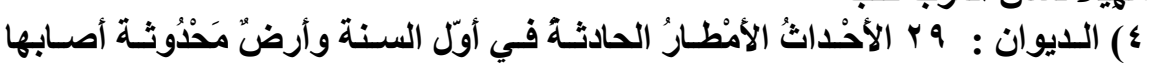

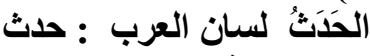

$$
\begin{aligned}
& \text { ه) القارعة: ؛ }
\end{aligned}
$$

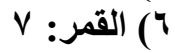


فقد شبَّه القرآن أحوال الناس في ذلك اليوم في كثرتهم وحيرتهم واضطرابهم وانتشارهم في كل جهة بالفراش المتفرق المتطاير، المنتشر عائر هنا وهناك على غير نظام،كما شبههم في كثرتهم وتتابعهم بالجراد المنتشر : فالناس عند خروجهم من قبورهم ( يخرجون فزعين لا يهتدون أين يتوجهون، فيلخل بعضهم في بعض، فهم حينئ كالفراش المبثوث بعضه في بعض لا جهة له يقصدها فإذا سمعوا المنادي قصدوه فصاروا كالجراد المنتثر، لأن الجراد له جهة يقصدها )(').

فقا حرص الشاعر على تصوير خروج الناس من قبورهم كما صورهم القرآن ، وكما وصف القرآن الفراش بكونه مبثوثا للالالة على كثرة الناس في هذا اليوم و تهافتهم حرص الشاعر على الإبقاء علي هذا الوصف وتوظيفه وان كان قيده بالكثبان استكمالا لتفاعيل البيت ،

أما الوصف الآخر فقد تناوله الثاعر في صورة تثبيهية حاول من خلالها الالالة على الانتشار والكثرة والتتابع، إلا أن تصوير القرآن كان أوجز

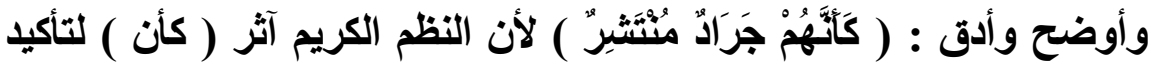
التثبيه (广) وللالاية على قوة الثبه ؛ ولذا قال حازم القرطلجنى في منهج البلغاء : وإنما تستعمل ( كأن ) حيث يقوى الشبه حنى يكاد الرائي يشك في أن المشبه هو المشبه بها أو غيره ولذلك قالت بلقيس: \} كَأنَّهُ هُوَ

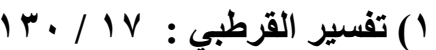
Y r الأكثر على أن كأن مركب من كاف التشبيه وأن المؤكدة الإتقان في علوم القرآن : \& $1 / 1$

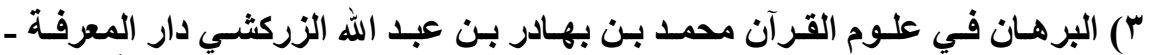

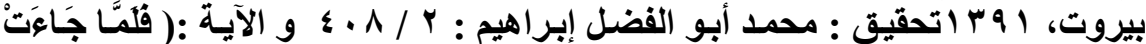

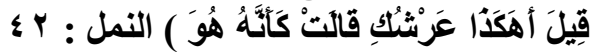


كما شبههم بالجراد المنتشر حيث أراد ( أنهم يخرجون فزعين لا جهة لأحد منهم يقصدها، كالجراد لا جهة لها، تكون مختلطة بعضها في

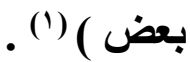

وهذا ما قصر بيان الثاعر عن الإشارة إليه .

كما تناول الثشاعر موقفا آخر من مواقف يوم القيامة حيث يُجْمَع

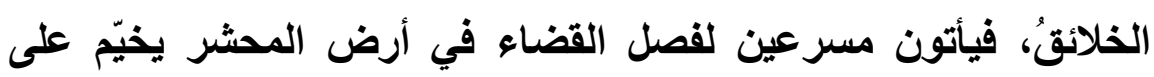
الساحة جلالُ الصمت ورهبة الخشوع :

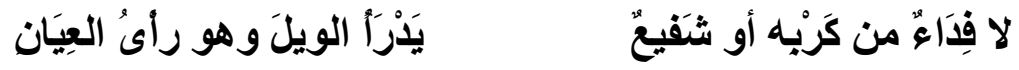

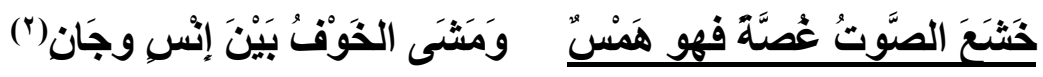

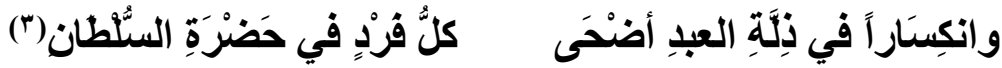

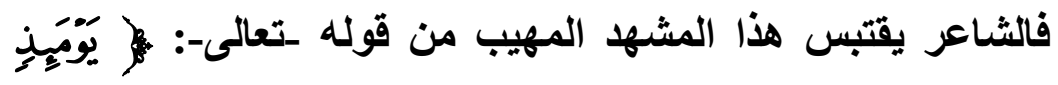

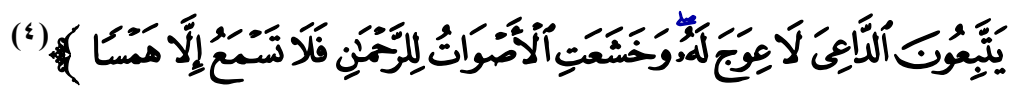
فالآية تتحثث عن سعي الناس إلى المحشر يملكهر الخشوع والسكون والخضوع والإنصات، انتظارا لحكم الرحمن فيهم. ومعنى : قُلا تَسْمَعُ إلا هَمْسًا \{أي : صوتا خفيا كما يرى ابن عباس،

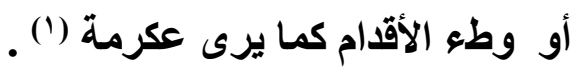

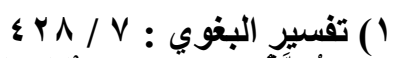

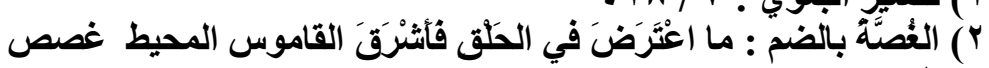
צr 
والآية الكريمة جاء فيها إسناد الخشوع إلى الأصوات وهو إسناد مجازى فإن الخشوع لأصحاب الأصوات؛ أو استعير الخشوع لانخفاض

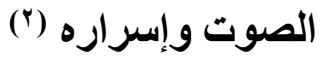

وفى ذلك مبالغة في الخشوع و تخافت الكلام ، وقد اقتبس الشاعر هذه الصورة القرآنية وأفاد منها وان كان قد تصرف فيها فأضاف إليها التمييز (غصنَّة) زيادة في تجسيد حالة السكون و المخافتة التي أفصحت

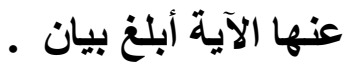

و في ثنايا تناوله لبعض الأدلة والبراهين على وجود الله، ووحدانيته وقدرته عَلى البَعْثِ وَالُْشُور ، ساق الشاعر بعض المشاهد الرهيبة والأهوال المفجعة التي يراها الناس يوم الحشر الأكبر :

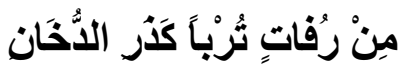

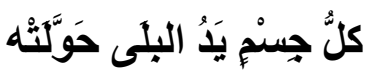

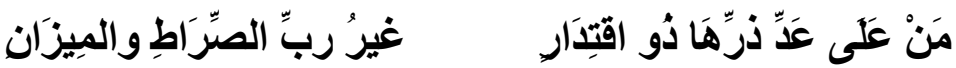

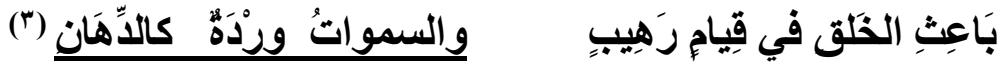
فالثاعر قد اقتبس هذا المشهر الرهيب الأي تتحول فيه السماء يوم القيامة و يتغير لونها ويختل نظامها من القرآن الكريم قال-تعالى-: فَإِذَا

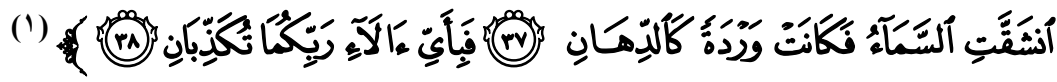


فالآية الكريمة جاعت في ثنايا تعديد آلاء الله الباهرة، ونعمه الكثيرة

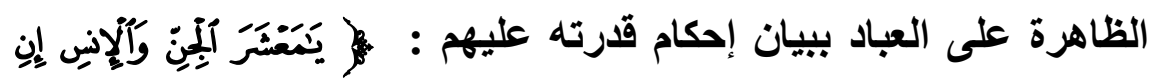

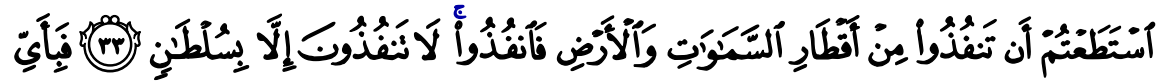

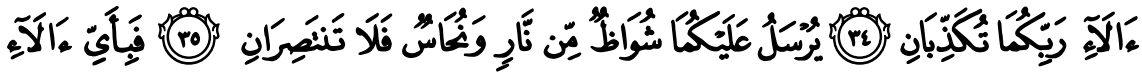
(َ)

وقد تساعل الإمام الزركشى عن (أي نعمة هنا وإنما هو وعيد مبينا أن نعم الله فيما أنذر به وحذر من عقوباته على معاصيه ليحذروها

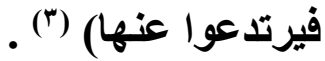

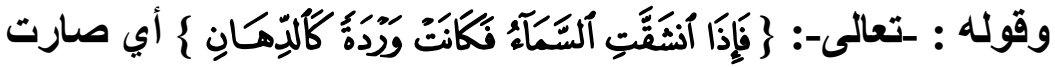
حين انشقاقها وتصدعها ،كالوردة الحمراء في لونها ، وكالدهان الذي يدهن به الشيء في ذوبانها وسيلانها .

و قد علق الرُّمانى على هذه الآية بقوله : ( فهذا تثبيةهُ قد أخرجَ ما لم تجر به عادة إلى ما قد جرت به ، وقد اجتمعا في الحُمرةِ ، وفى لين 
الجواهر السيََّّلةِة وفى ذلك اللالة على عظيم الثأن ، ونفوذ السلطان ،

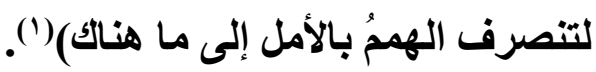

وكما نرى فق اقتبس الثشاعر هذا المشهـ الرهيب من القرآن الكريم

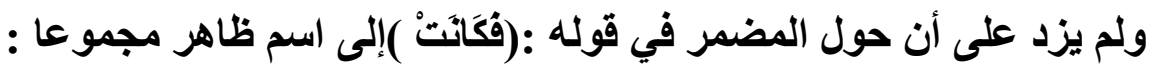

(السماو ات ) ليتسنى له الإسناد إليه لتكوين جملةٍ حاليةٍ زادت من الترهيب

والتخويف .

و هذا الاقتباس قد تكرر :

ففي ختام نونيته الكبرى يذكر الشاعر بيوم القيامة وما فيه من أهوال

مخرا من مشهـ الحساب وعرض السجلات :

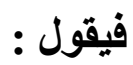

فيه تمَّتْْ صَحيفةُ الإنسان

سُجِّلتْنْ فيه صادقاتُ البَيَان

وجُلمودٍ و وأعْيُنْ و ولِسنَان

من دَيَاجِى أججَاَثِكم في أمَان

و السمواتُ ورددة كالدِّهَان

أو فِرَراراً مما تَرَى وتُعَانِى

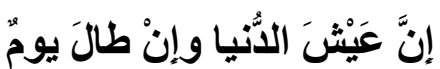

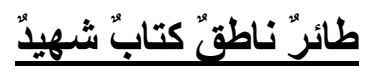

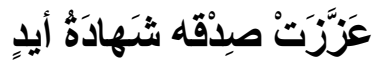

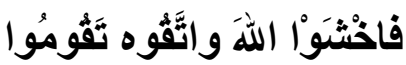

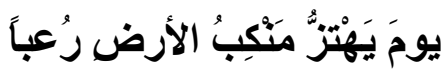

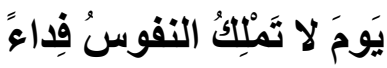

(1) النكت في إعجاز القرآن لأبى الحسن على بن عيسى الرماني ـ ضمن ثلاث رسائل في

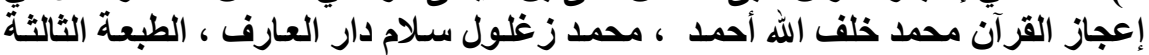




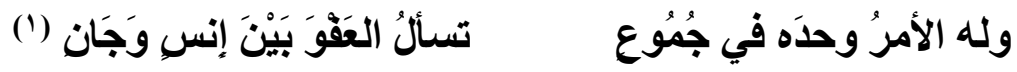

فقد جعل للأرض منكبا يهتز رعبا حال تحول السماوات إلى وردة

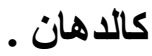

وفى بداية همزيته الكبرى يُسندِي الثـاعر تُصحَه و إرشاده فيدعو إلى

الاعتصام بلدين الله والاستعانة به و التحذير من القيامة وأهوالها :

تعلمُ الأرضُ قدرَه والسماءُ

يـا بني الأرض إنَّ للّهِ مُعحًَا

قادر" دائماً على ما يشاءُ

إن رباً يُدَبِرُ ملكاً كهذا

بينَ حرفين أمرهُما والقضاءُ

حارتُ الخلقُ في تصور ذاتٍ

مَنْْ لهه الحمدُ غيرُه والثناءُ

مالثكَ الملتكِ إنَّ وعدكَ حقٌّ

كلُّ أمر ويَسنتَكِنُ الهَهوَاعُ(َ)

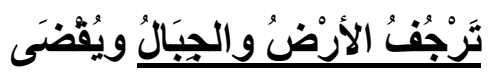

فقد اقتبس الشاعر هذا المشه الرهيب لتحرك الأرض وارتجاجها

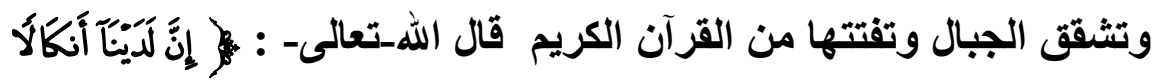

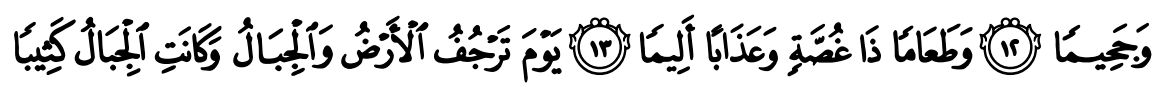
(")

V V

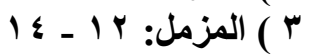




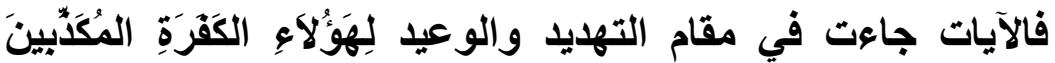
أرباب الغنى والترف والتلذذ في الانيا حيث توعدهم الله ـتعالى- بألوان من

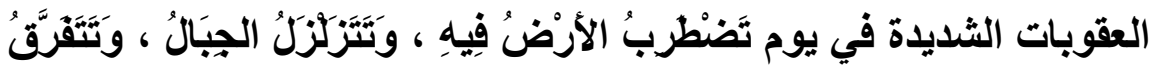

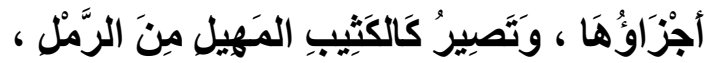

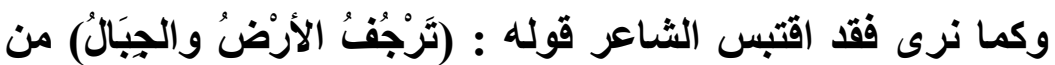
الآية الكريمة دون أن يغير فيها حرفا .

وما يحدث للأرض ، فسيكون حادثا للسماء أيضا وما فيها ، فالسماء سوف تنفطر ، والكواكب ستتدثر وهذا المعنى قد صوره الثاعر

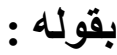

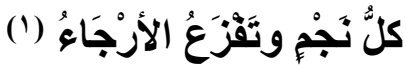
و نَمُوْزُ السَّماءُُ مَوْرَاَ ويَهْوَى

وهو في ذلك شأن كل الأمور الغيبية التي تفرد بذكر تفاصيلها القرآن

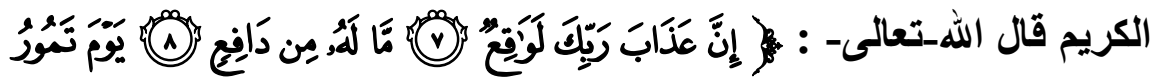

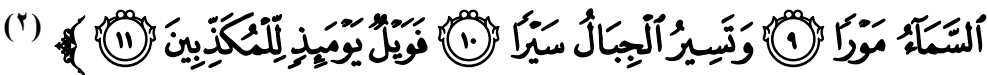
والآيات وردت في مقام التهايد والوعيد بوقوع العذاب للمشركين المكذبين بالنبي -صلى الله عليه وسلم - مبينة أن هذا العذاب ليس له مِن مانع يمنعه حين وقوعه ، يوم تتحرك السماء فيختلٌ نظامها وتضطرب

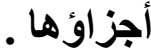

$$
\begin{aligned}
& \text { Y ) الايوان : VT }
\end{aligned}
$$

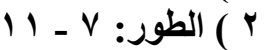




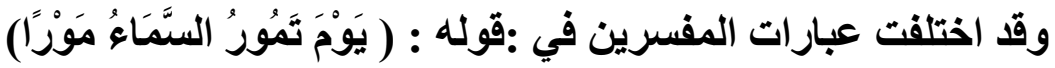
فقال ابن عباس : يوم تثقَّق السماء وعن مجاهد : تدور دورا، وعن قتادة، (') :

وكلها معان متقاربة فأصل المَوَز الاختلاف والاضطراب و"|لمور" يجمع هذه المعاني، فهو في اللفة: الذهاب والمجيء والتردد والدوران

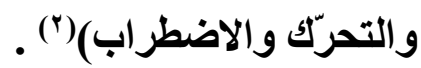

وأكد الفعل بمصدره للإيذان بغرابته و وخروجه عن الحدود المعهودة

أي : مَوراً عجيبًا لا يُرك كنههه ، و لرفع توهم المجاز في الفعل) (") . وقد أفاد الثاعر من كل هذه النكات البلاغية ووظفها خدمة لمقام الزجر و التهايد والوعيد فكان هذا الاقتباس الذي لم يغير فيه الثاعر حرفا. ويمضى الشاعر للحديث عن الساعة و أثراطها فيقول :

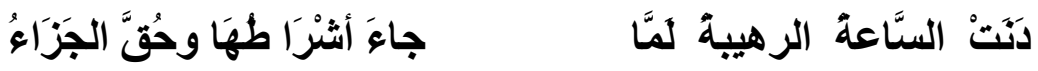

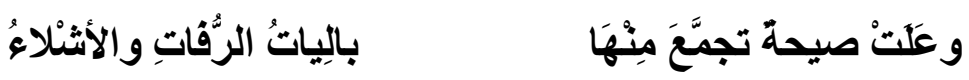

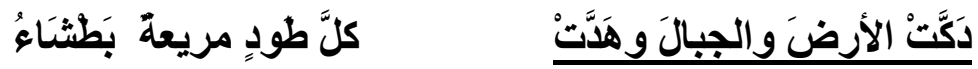

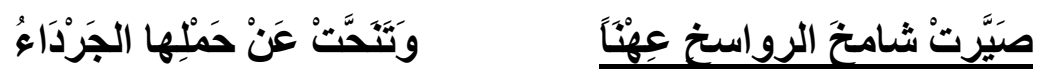

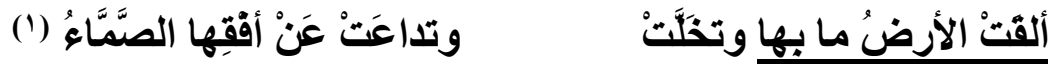




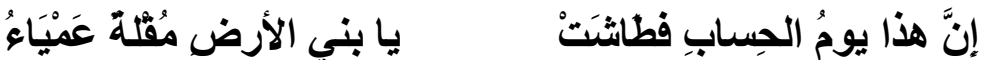

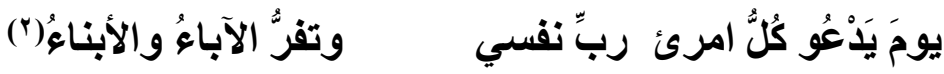
فالشاعر يصور جانبا من مشاهد يوم القيامة وأهو الها حيث

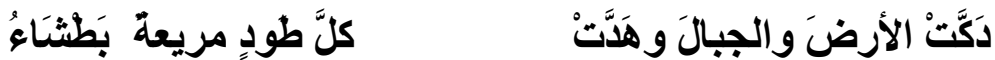

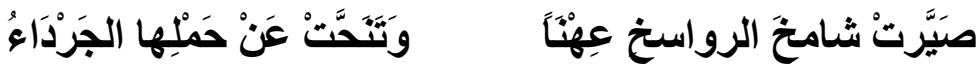

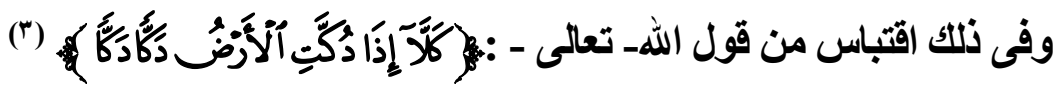

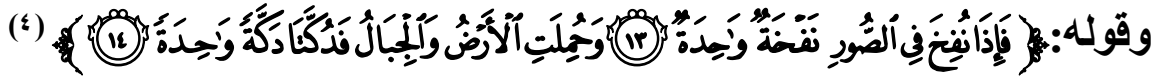

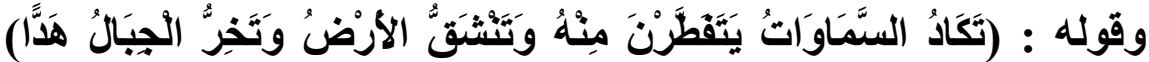

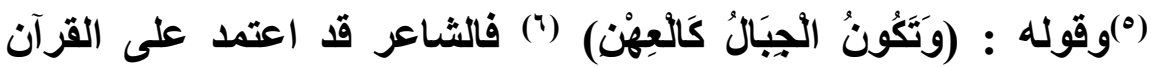
الكريم واقتبس منه فالأرض تدك والجبال تهـ وتصير عهنا .

ويضيف مشهرا آخر يزيد من رهبة الموقف وشدته هيث ثُبَادِرُ الأرضُ بإخراج ما في بطنها من الأموال والكنوز والأموات وتتخلى عنهم :

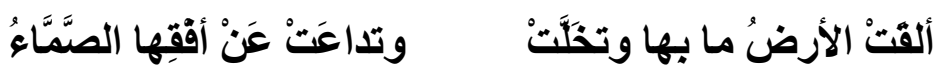

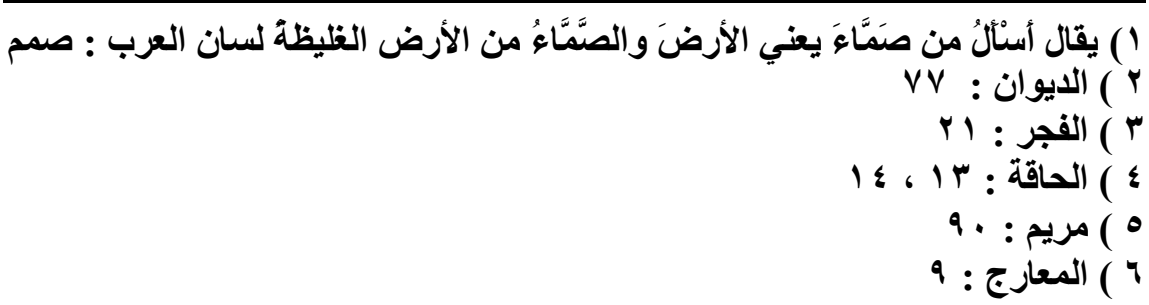




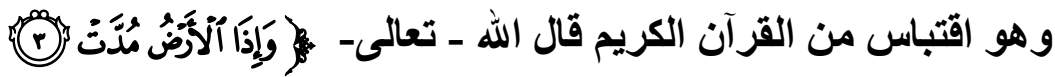

\section{(1)}

فالآية الكريمة تصور ما يحدث يوم القيامة للأرض ومعنى (وَألقتََّْا

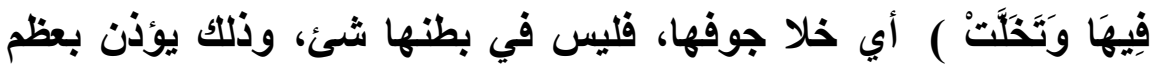

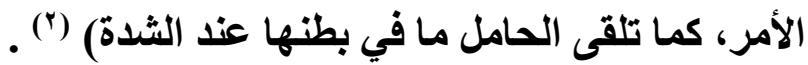

وقد آثر النظم الكريم مادة التفعل في( تَخَلَتْن) للالالة على أن الأرض (خلت غاية الخلو حتى لم يبق شيء في باطنها ، كأنها تكلقت أقصى جهدها

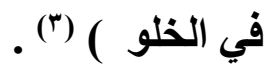

وإسناد هذه الأفعال للأرض إسناد مجازى وَوُصِقِت الأرض بذلك توسعاً و(كأنها فاعلة له على هذا الوجه ، فصارت خلية عن كل شيء كان

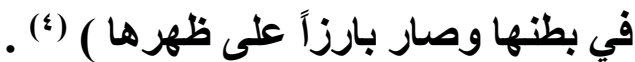

وقد حرص الثاعر على الإفادة من هذه النكات وتوظيفها وذلك

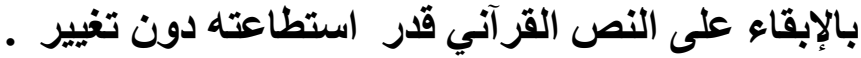
ويمضى الثاعر إلى الحديث عن الموت وشدته وما يعقبه من أهوال

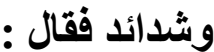

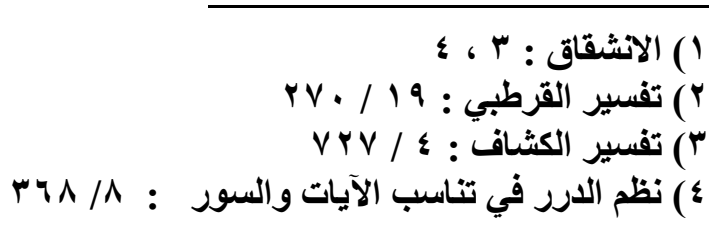


ويُسَاقُ الضِّعافـُ والأقَوياءُ

حائرات من هَوْلِهِ هَلَعَاعُ

ولهه الأمرُ وحدَهُ والقضَاهُ

عن سبواها ولا يُفِيدُ القِدَاكُ

وفؤادُ وكلُهَا رُقبَاءُ

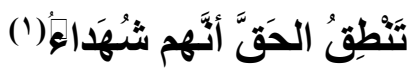

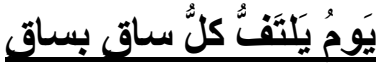

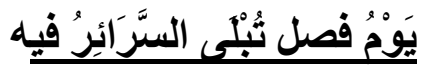

يومَ لا تملِكِكُ التفوسُ اتتصاراً

كلُّ نفس يُعْنى لها فيه شأنُ

كلُّ نفس لها لِسنَانٌْ وعَيْنِ

تُمَّ أيدٍٍ وأرجُلِ وجلودِ

\section{فالشاعر يعرض مشاهد متنوعت لأهوال يوم القيامتّ :}

فبدأ بمشه الاحتضار بتفاصيله الدقيقة والذي اقتبسه الشاعر من

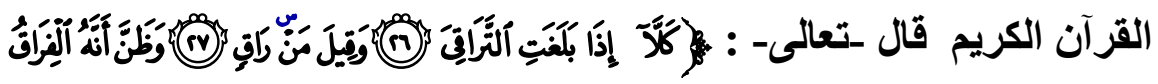

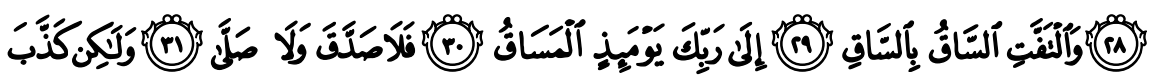

(v)

فالآية الكريمة تصور لحظات خروج الروح وتصف الحالة التي يتهيَّأ بها المحتضر حيث ( النَََّتِْ السَّاقُ بالستَّق) والمراد ساقا الميت عندما لفا في الكفن ، أو أن التفاف الساقين كناية عن شدة الأمر وعظم الخطب والتقاء الأهوال بالأهوال ، أو أنه من (باب التمثيل ) للأمر الهائل العظيم ، 
حيث يلتقي عليه شدة كرب الانيا ، مع شدة كرب الآخرة ، كما يقال :

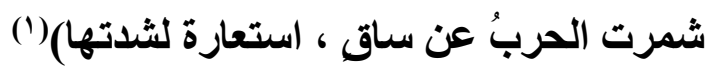

كما اشتنمل النظم الكريم على الجناس الناقص في (السَّاق ، المَسَتق)

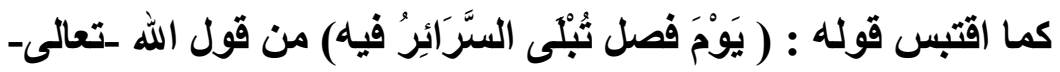

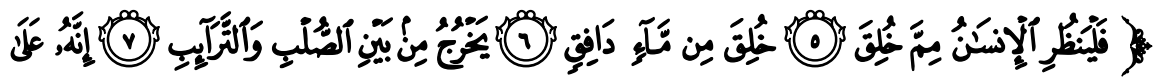

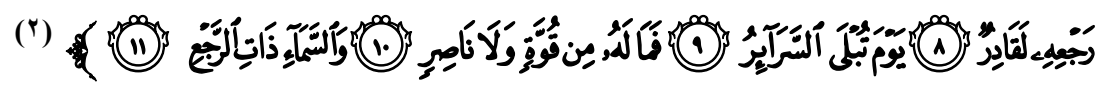

فالآية الكريمة جاءت في معرض إثبات قدرة الله ـتعالى- على البعث وإعادة الإنسان بعد الفناء ،لأن إعادة خلق الإنسان ليست أصب من خلقه

ومعنى (ثُبْلى السَّرَائرُ ) ) أبي تظهر الخفايا و تُخْتَبر السرائر فيما أخفته، ويُمََّزّ الصالح منها من الفاسد، وهو كناية عن الحساب عليها

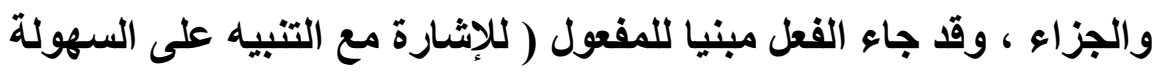

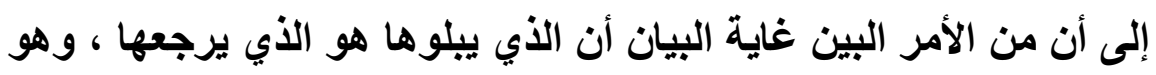
الله - سبحانه وتعالىـ من غير احتياج إلى ذكره )(") . كما جاء قوله : - كائ

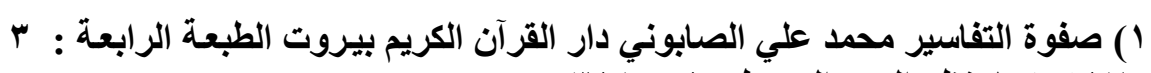

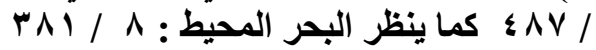

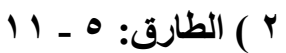

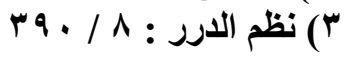




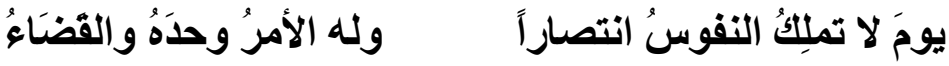

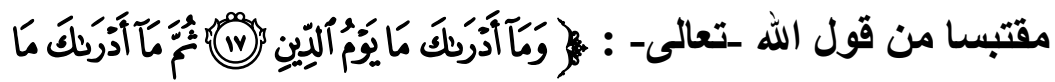

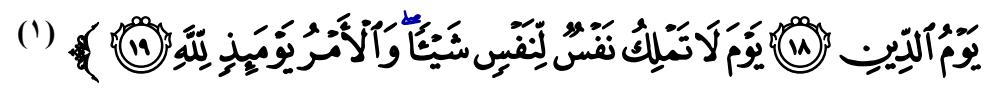

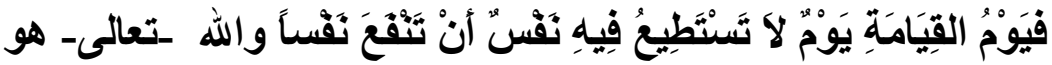

المتفرد بالأمر في الانيا والآخرة ، والأمر هنا بمعنى : (التصرف والإذن

وهو واحد الأوامِر ، فإن الأمر من شأن الملك المطاع) (ب).

وجاء معرفا لإرادة الاستغراق والقصر أي الأمر لله-تعالى- وحده لا لغيره ،وكل هذه النكات البلاغية استحضرها الثاعر واقتبسها ووظفها

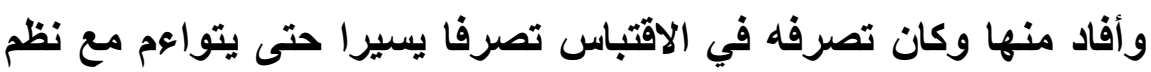

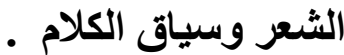

كما جاء تعليله لضعف الخلائق وعجزهم الثامل عن نصرة بعضهم بضا يوم القيامة مقتبسا من القرآن الكريم فقوله :

عن سيوا ها ولا يُقِيُُُ الفِدَاءُ

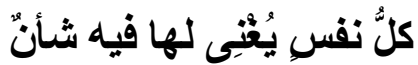

\footnotetext{
1) الاتفطار: IV 19

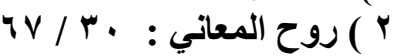




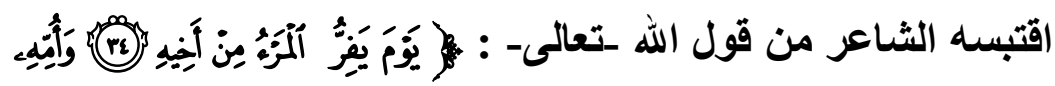

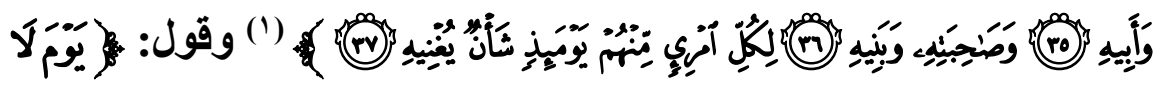

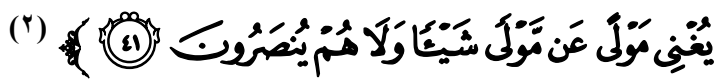

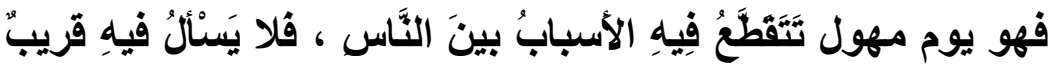

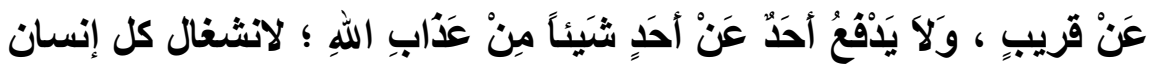

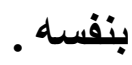

والثاعر كما نرى قد استلهم هذا المعنى واقتبسه وصاغه صياغة

شعرية .

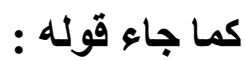

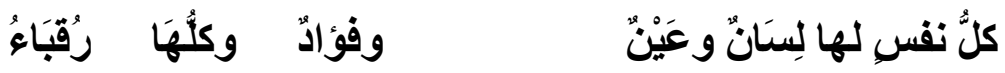

$$
\text { تُمَّ أيدٍ وأرجُلِ وجلودٍ }
$$

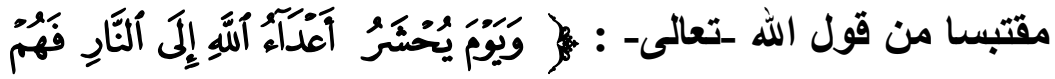

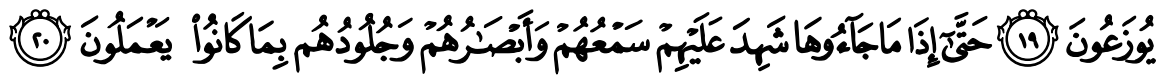

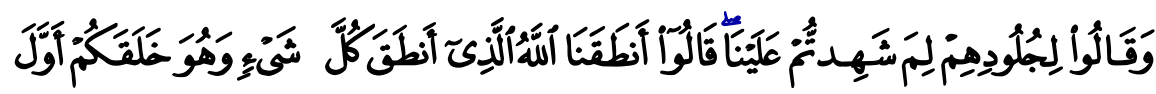

$$
\begin{aligned}
& \text { ( ) (ل) } \\
& \text { r }
\end{aligned}
$$




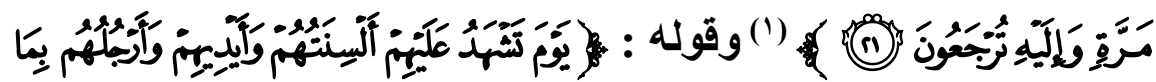

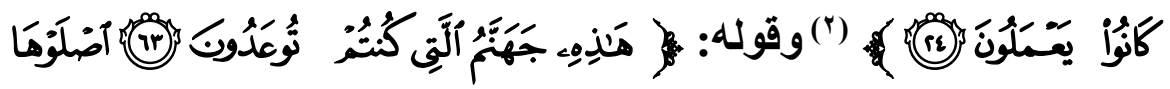

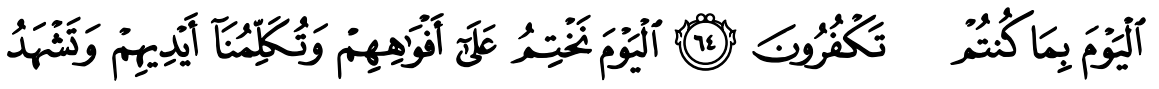

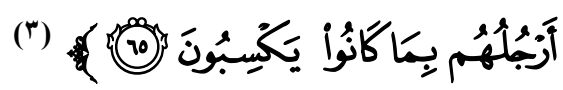

فالآيات تصور موقفا من مواقف العرض والحساب حيث يُنَكِرُ الكُقَّرُ

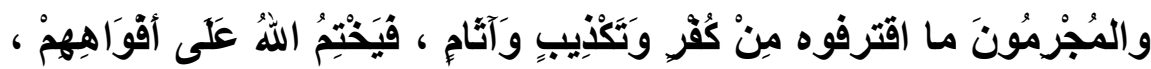

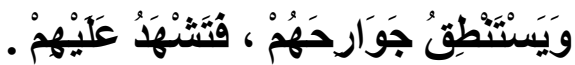
والثهادة شهادة تكذيب وافتضاح زيادة في الإحساس بالخزي لهم

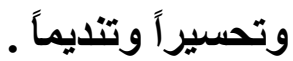

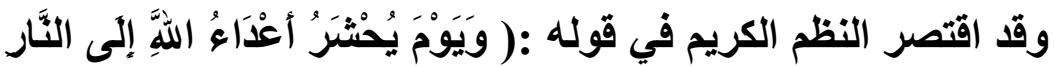

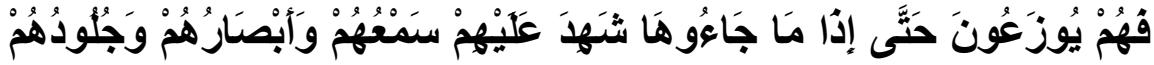
بمَا كَائوا يَعْمَلَون) على حواس :( السمع و البصر واللمس )لأنها الحواس التي جاء فيها التكليف ، كما أنها المباثرة لغالب المعاصي بخلاف الثم فلا تكليف فيه(")

أما آية النور فقد وردت في مقام حَيِيثِ الإقلَكِ الذي أطلقهُ بَعْضُ

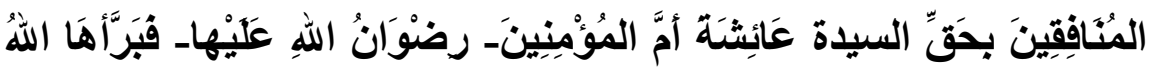

$$
\begin{aligned}
& \text { ( ) فصلت : } 19 \text { : } 19 \\
& r
\end{aligned}
$$

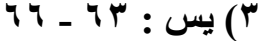

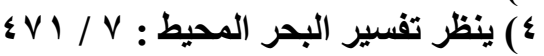




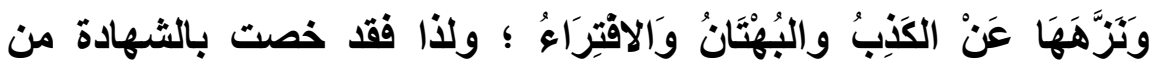
الجوارح : : الألسن والأيدي والأرجل)(لأن لهذه الأعضاء عملاً في رمي المحصنات فهم ينطقون بالقذف ويشيرون بالأيدي إلى المقذوفات ويسعون بأرجلهم إلى مجالس الناس لإبلاغ القذف )(') . والثاعر كما نرى قد حذر بلغته الشعرية من يوم القيامة ومن هذا الموقف المهيب حيث تشهد الجوارح بما اقترفت شهادة تكذيب وافتضاح مزيدا في الإحساس بالخزي وتحسيراً وتتديماً ، وهو في ذلك متأثرٌ بالقرآن الكريم ومقتبس منه جامعا بين تلكك الجوارح التي أوردتها الآيات عدا حاسة السمع التي أغقلها الثاعر ، مضيفا إليها الفؤاد الذي لـم يرد ذكره في

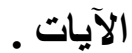

كما صور الثاعر خروج الناس من أجداثهم يملأهم الخوف والفزع ، ويحدوهم الرجاء والأمل متأثرا بالقرآن الكريم ومقتبسا منه فقال :

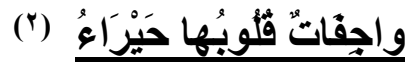

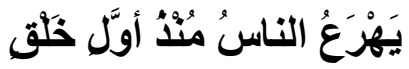

أقَز عَتَها من نومِهِا الدَّهْمَاءُ بعثرْنَها القبِورُ تجرى سِرَاعَاً

كجرادِ يضيقُ عنه القضَاءُ ماجتُ الأرضُ تحتَ أقدام خلق فوقهم تُمْطِرُ العذابَ السَّمَاءُ

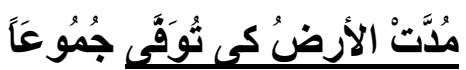

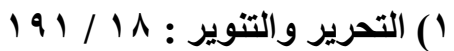

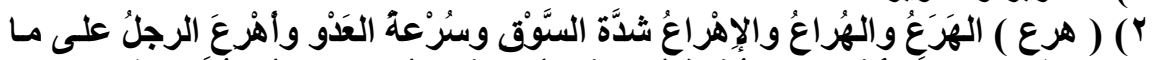

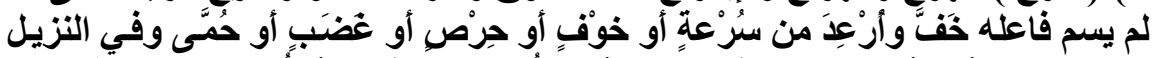

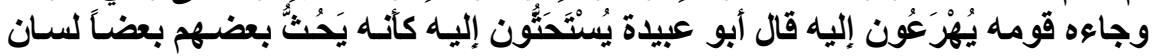

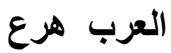




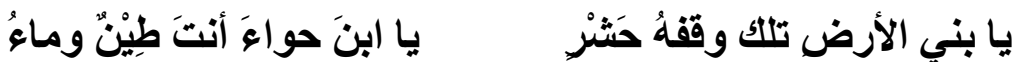

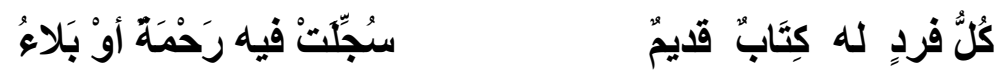

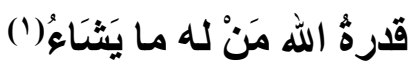

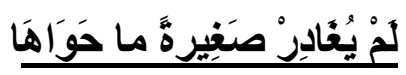

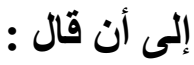

أبَدَ الاَّهر كي يدومَ الثناءُ

كلُ شَيَعِ يُسبِّحُ اللهَ حمداً

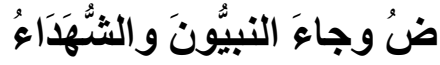

وينورِ الإلهِهِ أشْرَتَتْ الأر

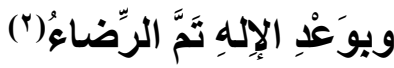

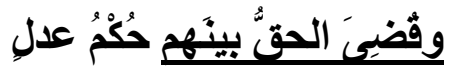

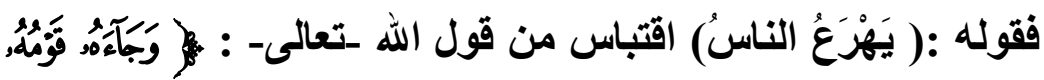

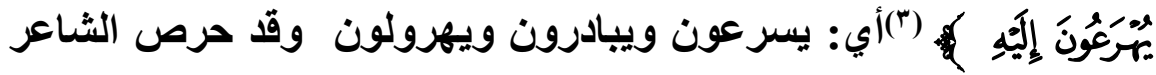

على اقتباس الفعل مبنيا للمفعول كما ورد في الآية الكريمة للإشارة إلى نوع من السير يتناسب وهول الموقف فأصل الهرع ( مشي الأسير الأي يُسرَع به ـ وهذا البناء يقتضي أن الهَرْع هو دفع الماثي حين مشيه؛ إلاً أن ذلك تتوسيَيَ ، وبقي أهرع بمعنى سار سيراً كسير المدفوع )(؛' فالناس يخرجون من قبورهم يهرعون يتدافعون كأن سائقاً يسوقهم ويدفعهم . 
وقوله:( واجفاتُّ قلوبُها)ي فزعة شديدة الاضطراب من الخوف

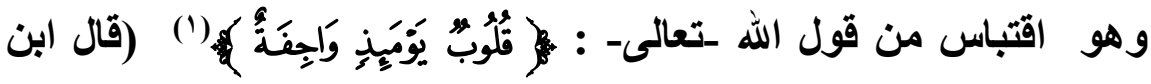
عباس: يعني خائفة ،وكذا قال مجاهل، وقتادة)(") .

والمراد بهذه القلوب : قلوب المشركين الذين أنكروا في الدنيا البعث

و الجزاء ، فلما بعثوا اعتراهم الرعب الثديد ، والفزع الذي لا يقاربه فزع) (") .

كما أن قوله :( بعثرئها القبورُ ) اقتباس من قول الله تعالى- :

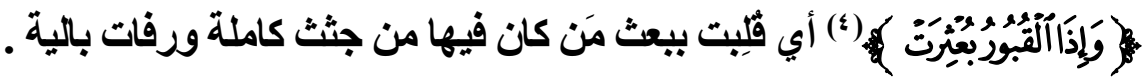

و قولهه :( مُدَتَّْ الأرضُ كى ثُوَفَى جُمُوعَاً) اقتباس من قول الله ـ

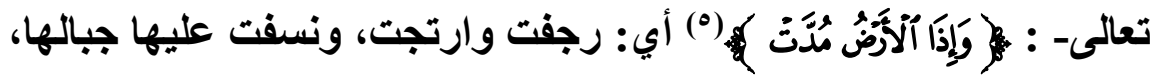

ودك ما عليها من بناء ومطلم، فسويت، ومدها الله ـتعالى ـ مد الأديم، حتى

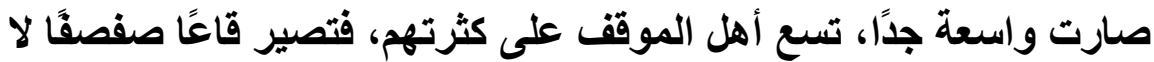

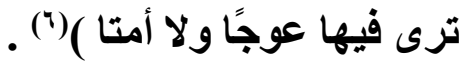

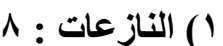

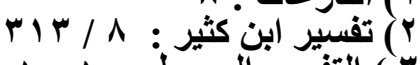

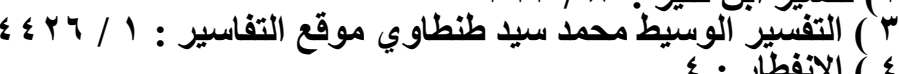

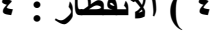

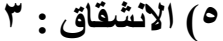

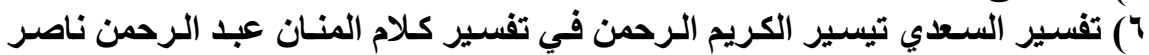

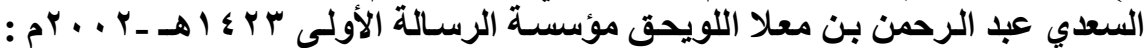




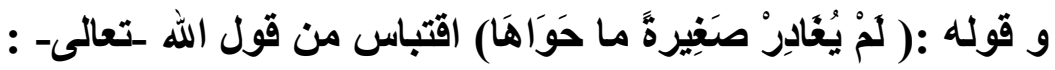

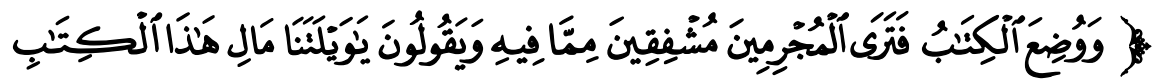

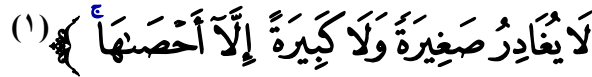

فالثاعر كما نرى ذكر مشاهد عدة لأهوال يوم القيامة اقتبسها كلها كما بينا من القرآن الكريم واختتمها بالحديث عن أرض المحثر حيث

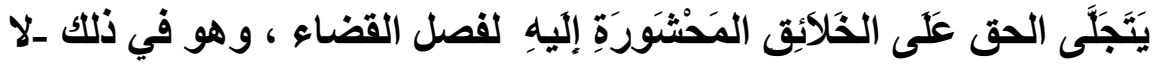

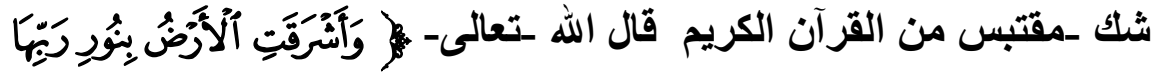

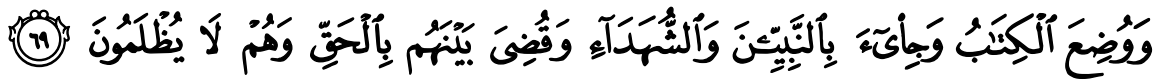

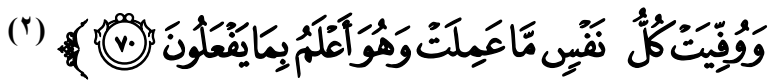

فالآية الكريمة تصف أرض القيامة حيث أشْرَقت بئُور رَبِّهَا حِينَ

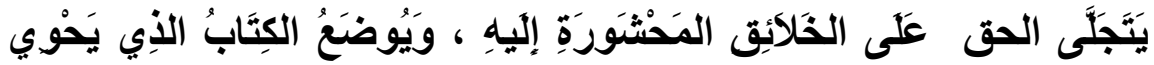

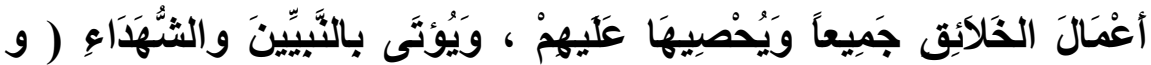

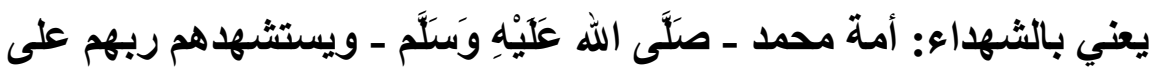
الرسل، فيما ذكرت من تبليغها رسالة الله التي أرسلهم بها ربهم إلى أممها، إذ جحدت أممهم أن يكونوا أبلغوهم رسالة الله)(") .

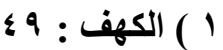 \\ V) - Y الزمر:

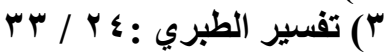


وكما هو ملاحظ فالأحداث والمشاهد في هذه الآية الكريمة لم تقع بعد، ولكن النظم الكريم آثز التعبير عنها بصيغة الماضي لتحقق الوقوع

$$
\text { (وكأنها أحداث قد تقضت، واتقضت)(') }
$$

كما آثر النظم إضافة النور إلى الرب إضافة تعظيم و تثريف

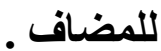

وقد اقتبس الشاعر هذا المشهر المهيب وصاغه صياغة شعرية متأثرا بلغة القزآن و مستفيدا بتلك النكات البلاغية وموظفا إياها خدمة ووفاء بمقام الترهيب والتخويف وكان تصرفه في الاقتباس تصرفا محدودا.

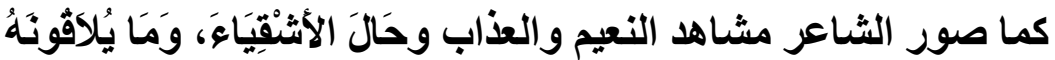

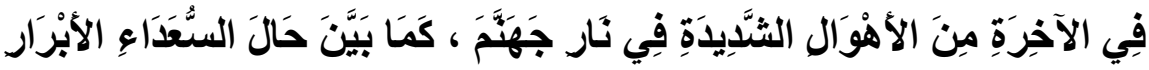

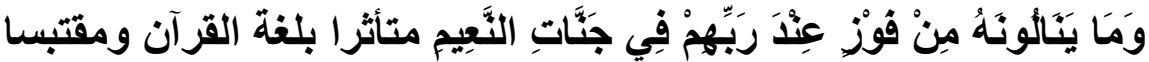
منه

فبعد الحديث عن صيحة القهر وأثرهاو قوتها على الخلائق :

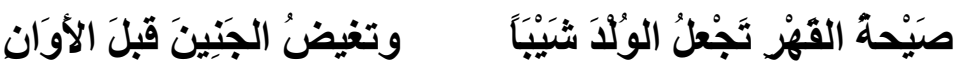

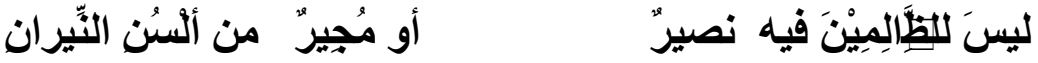

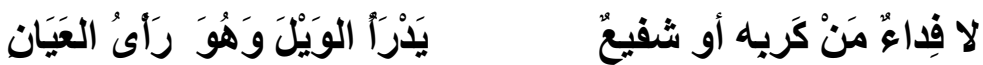

() ينظر خصائص التراكيب دارسـة تحليلية لمسـائل علم المعاني د محمد أبو موسى

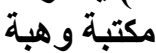

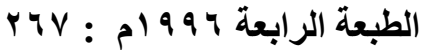




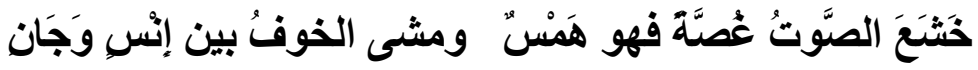

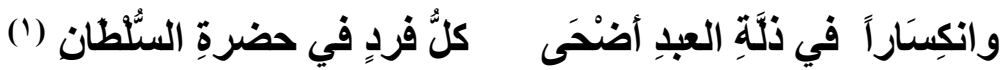

انتقل مهددا منككري البعث ومذكرا إياهمبما أعد لهم من عذاب أليم

وَجْحُوداً هوى إلىى النَّيران

كلٌ مَنْ أنكرَ القيامة كبراً

سوف يلقَى عَواقِبَ الكُقَرَان

بئس مثَواه في الجَّحِيْمِ وَعَدْلَا

أثنقلتُها الأغلالُ للأدَّقان وَسَنَصْلى السعيرَ فَى أصفادٍ

من جحيم وَهَّاجَةِ الأركان دركاتُّ سبعٌ طباقُ عذابٍ

وسيولُ الحَمِيْمِ فَى غُلِيَان سارياتُ السنُّوم تَنْسَابُ فيها

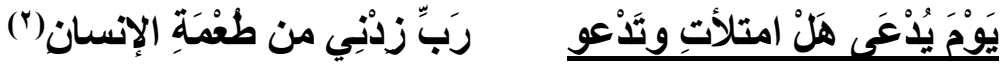

$$
\text { فقوله : - مقن }
$$

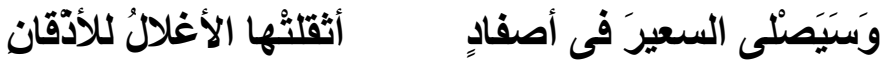

وصف لما أعِد لهولاء الأثقياء الجاحدين المنكرين للقيامة كبرا

وجحودا من سعير وأغلال .

والشاعر في ذلك متأثر بالقرآن الكريم و مقتبس منه قال الله ـتعالى-

:

$$
\begin{aligned}
& \text { ( ) الديوان : rان }
\end{aligned}
$$

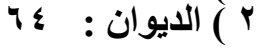

$$
\begin{aligned}
& \text { ب ) الإن }
\end{aligned}
$$


فالآية الكريمة تصور على سبيل الاستعارة التمثيلية حال هؤلاء الكافرين الجاحدين فِي تصميمهم على الكفر وتماديهم في الإنكار، بمن جعل في عنقه غل يمنعه من الالتفات ، وغطى على بصره فصار لا يرى ، والجامع مطلق المانع.

وهذا هو الرأي الأول والثاني أنها عبارة عن كفهم عن إذاية النبي ـصلى الله عليه وسلم - حين أراد أبو جهل أن يرميه بحجر ، فرجع عنه فزعاً مرعوباً ، والثالث : أن ذلك حقيقة في حالهم في جهنم ، والأول أظهر

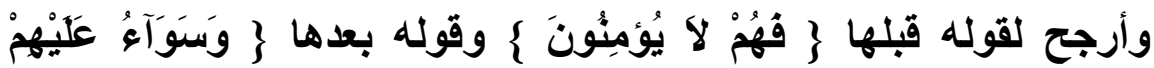

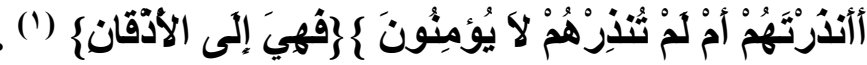

فالثاعر كما نرى اقتبس حديثه عن تلك الأغلال واستمده من هذه الآية الكريمة التي اشتملت على صورة بياتية أفاد الثاعر منها وأحسن توظيفها خدمة ووفاء للمقام .

ويمضى الشاعر فيذكر خطاب الله تعالى لجهنم وقد وعدها أنه سيملؤها من الجيَّة والناس أجمعين.

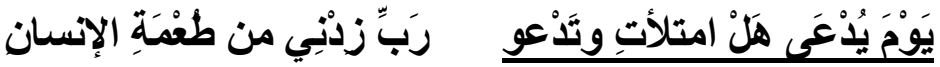
ويكرر هذا الخطاب قبيل ختام هزيته الكبرى فيقول :

( ) ينظر التسهيل لعلوم التززيل لابن جزي الكلبي محمد سـالم هاشـم دار الكتب العلمية

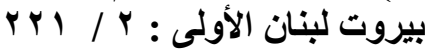




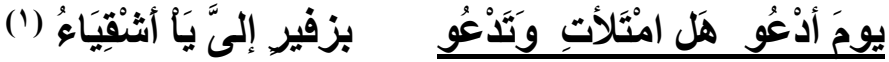

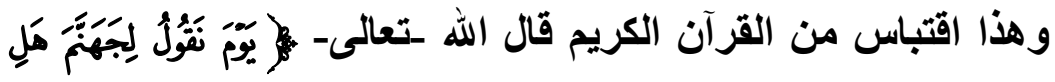

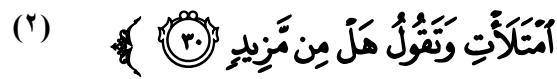

فالآية وردت في مقام التهديد والوعيد حيث يقول الحق لجهنم تقريعاً للكافرين : هل امتلأت ، وتقول جهنم غضباً عليهم : هل من زيادة أستزيل بها من هؤلاء الظالمين؟

واختلف في خطاب الله لجهنم وجوابها هل هما على الحقيقة أو لا

؟ فقال بعضهم هما على الحقيقة فينطقها الله بذلك كما ينطق الجوارح هات والله على كل شيء قدير فلا وجه للعدول إلى المجاز ، وقال بعضهم سؤال وجواب جيء بهما على منهاج التمثيل والتخييل لتهويل أمرها ولمعنى أنها مع اتساعها وتباعد أقطار ها تطرح فيها من الجنة والناس فوجا بعد فوج حتى تمتلى أو أنها من السعة بحيث ياخلها من ياخلها وفيها بعد محل فارغ أو إنها لغيظها على العصاة تطلب زيادتهم (") .

وسواء أكان السؤال والجواب على سبيل الحقيقة أو المجاز فقد نقل الثاعر هذا الحوار واقتبسه من الآية الكريمة وصاغه صياغة شعرية متصرفا في جواب جهنم و رغبتها في الزيادة والاستكثار من الاخلين فيها ـ

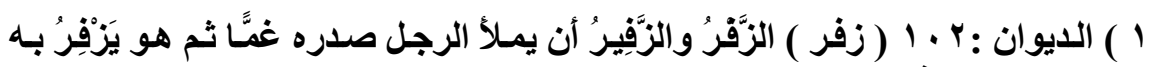

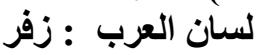

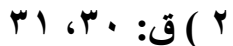

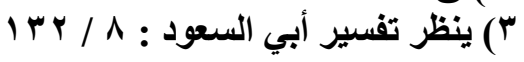


وإذا كان الشاعر في هذا الموطن قد تصرف في الاقتباس حيث استبدل استفهام جهنم بطلب صريح (رَبِّ زدنْبِ من طُمْمَةِ الإنسان) فقي موطن آخر ضمن شعره هذا الخطاب الرباني مقتبسا من الآية الكريمة السؤال والجواب دون تلخل منه في حرف : فبعد استعراضه لما دار بين الحق جل وعلا و إبليس عليه لعنة الله تطرق للحديث عن جهنم وما أعد فيها من عذاب أليم فقال:

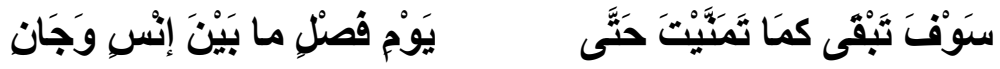

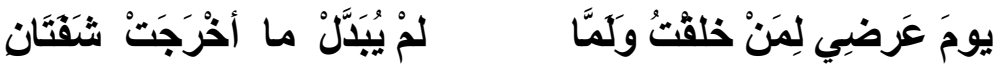

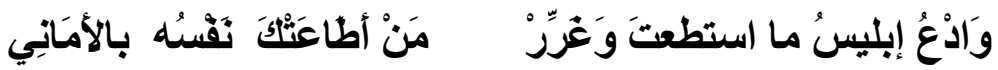

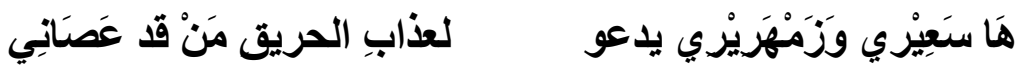

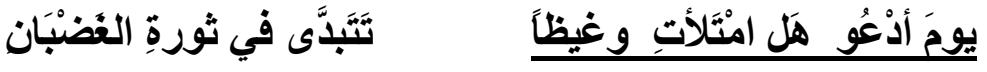

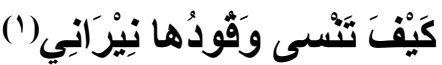

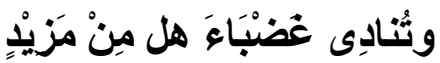

فعلى نهج القرآن فى استنطاق الجماد الأي لا ينطق، ومخاطبته كائَّهَ ناطق يتكلم سار الشاعر فإذا به يضمن بيتيه الأخيرين قول الله تعالى :

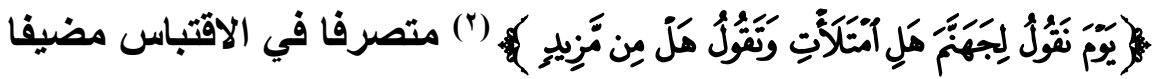
إلى الحوار ما يحافظ على وزن قصياته وما يعد تفسيرا لما أجمله النظم الكريم وتوضيحا لما أوجزه . 
كما تناول الشاعر متأثرا بالقرآن الكريم ومقتبسا منه حال الكافرين وكيفية سوقهم إلى نار جهنم مبينا ما أعِدَّ لهم من عذاب مقيم و شدائد

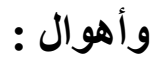

يستغيثُونَ حَيْثُ حلَّ البِلاعُ

واسنَشَْاطت مِنْ عَيْظِهَا الرَّمْضَنَاءُ

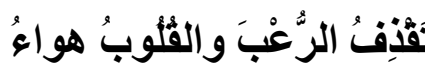

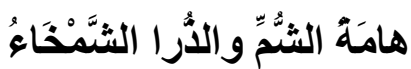

$$
\text { رِجَّعتْهُه من هولِهِ الأرجاءُ }
$$

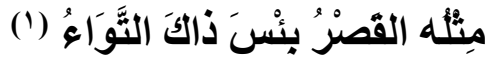

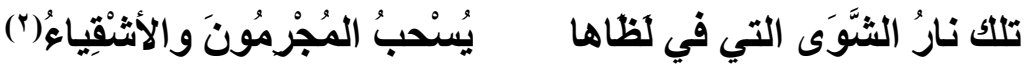

ووقودُ السعير زادَ اشتِعَالاً

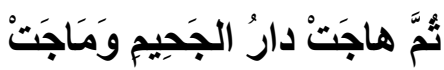

في زفير كالر عدِ تَنْلكُ منه وشهيق ينقضٌٌ من كلِّ فج

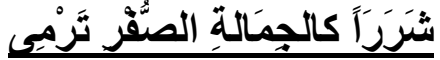

ققد بلأ الثـاعر حديثه عن أهل الشقاوة باقتباس قرآني قال تعالى :

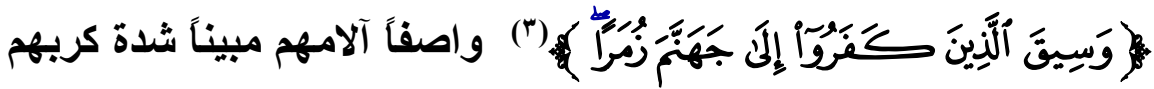

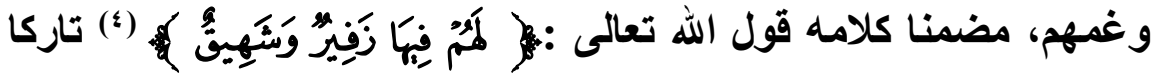
لخياله العنان فى رسم صورة بيانية يزيد بها من هول ما يلاقونه ف فالزفير

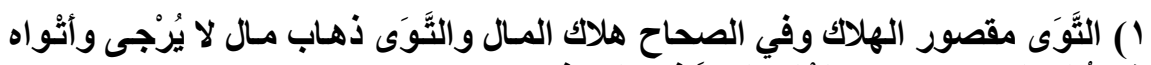

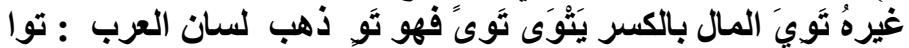

$$
\begin{aligned}
& \text { r } \\
& \text { צ ( الزمر: الايوان } \\
& \text { ؛ ) هود: } 1 \text { ) الرهر: 1 }
\end{aligned}
$$


كالرعد تتدك منه هامه الثم والذرا الشمخاء والشهيق كأنه وحش ينقض من كل فج رجعته من هوله الأرجاء

واصفا الثرر المتَطايرَر مينَ التَّار زيادة في الترويع والتهويل بما

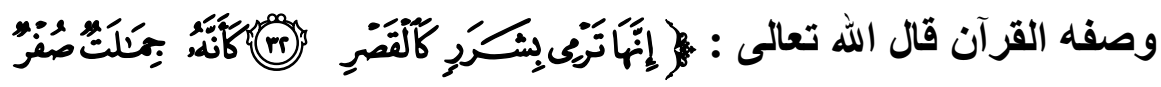

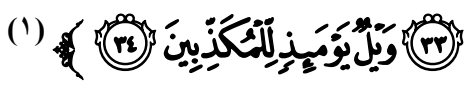

فالآيات تتحدث عن نار جهنم وأنها تقفت قاطنيها بشرر كالقصر فى عظمه ضخامته و بالجمال الصفر في هيئتها ولونها وسرعة حركتها

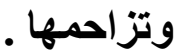

واختير اللون الأصفر للجمال ، لأن شرر النار عندما يشتد اشتعالها يكون مائلا إلى الصفرة .وقيل المراد بالصفر هنا : السواد ، لأن سواد الإبل يضرب إلى الصفرة .

وقيل : الضمير في 》 إنه 《) يعود إلى القصر ، فيذهب به إلى تصوير عجيب وتطوير غريب ـ شبهت الشرارة حين تنقض من النار في العظم بالقصر ، ثم شبّه القصر المشبّه به ، حين يأخذ في الارتفاع والانبساط بأن ينشق عن أعداد لا نهاية لها بالجمالات المتكاثرة ، فيتصوّر فيها حينئذٍ 
العِظم أولاً ، والانثقاق مع الكثرة والصُفرة و الحركة ثانياً ، فيبلغ بالتشبيه

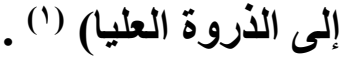

فالثاعر كما نرى قـ اقتبس هذا التشبيه من القرآن الكريم وتصرف فيه بتعريف أحد المشبه بهما وهو الجمالة الصفر . ثم يتابع الثاعر حليثه عن جهنم واصفاً حراسها :

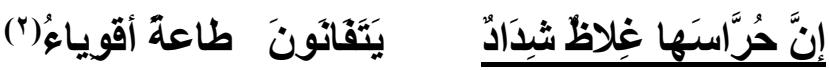
وهو فى وصفه هذا معتمد على القرآن الكريم مقتبس منه قال الله

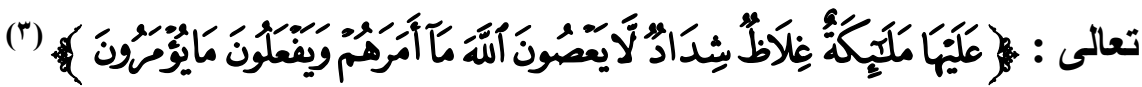
والآية الكريمة تصف زبانية جهنم مبينة مقدار طاعتهم لربهم وعدم عصياتهم لأوامره بما يعرف لاى البلاغيين بالطرد والعكس(4) · فجملة:

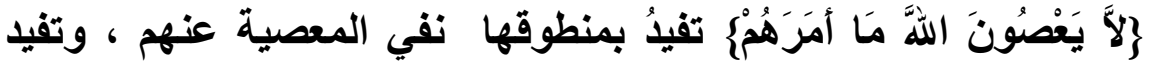
بمفهومها إثبات الطاعة لهم ، و جملة: بمنظوقها إثبات الطاعة لهم ، وَتقيد بمفهومها نفيَ المعصية عنهم . و قدلاظ اقتبس الشاعر من النظم القرآني وصفين لزبانية جهنم شِدَدادُ ) دون تغيير فى اللفظ القر آني وأما وصفهم بالطاعة وعدم العصيان 1) البحر المديد أحمد بن عجيبة الحسني الإدريسي دار الكتب العلية بيروت الطبعة

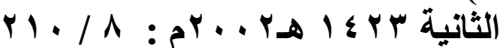

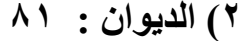

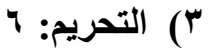
؛ ) وهو أن يؤتى بكلامين يقرر الأول بمنطوقهـ مفهوم الثاني وبالعكس : الإتقان في

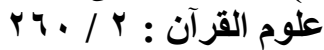


فقد سلك الشاعر طريقا آخر فوصفهم بالتفاني فى الطاعة مشيرا بصيغة المستقبل (يتفانون ) إلى التجدُّد كناية عن استمرارهم فى الطاعة حالا واستقبالا وأن هذا شأنهم لا ينقك عنهم .

ويتابع الثاعر حديثه عما ما أعد للعصاة من عذاب فى جهنم فيقول :

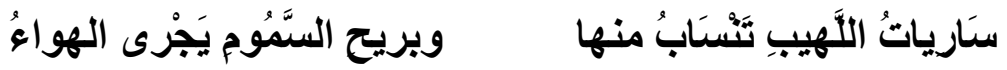

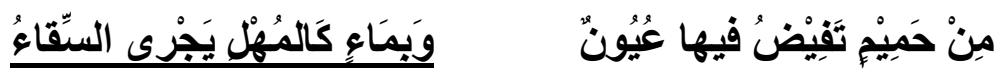
منهله تُشْوَى الوُجُوهُ والأمَعَاُُ

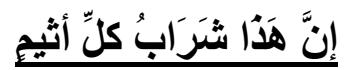

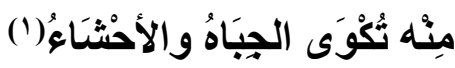

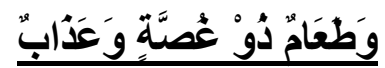
فالثاعر يصف شراب أهل الجحيم و طعامهم معتمدا على القرآن الكريم

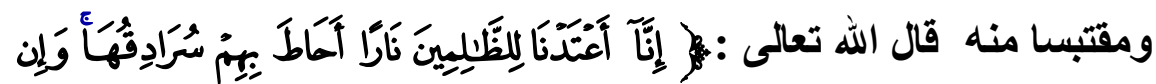

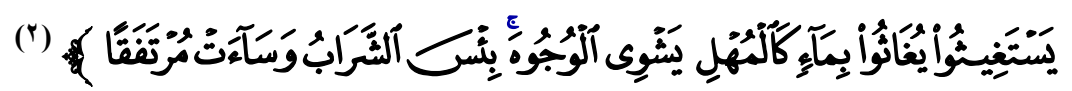

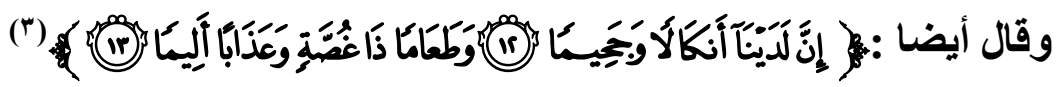
فالآية الأولى تتحدث عما أعد للظالمين من عذاب الجحيم والحميم

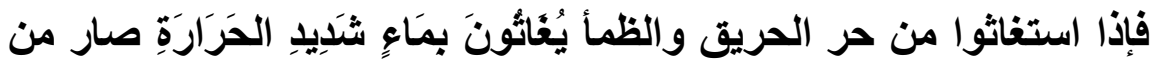
شِدَّةِ حَرِِّ كالمهل يشوى وجوههم قال ابن عباس : المهل الماء الغليظ مثن

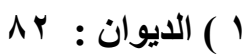

$$
\begin{aligned}
& \text { r الكهف: } 9
\end{aligned}
$$

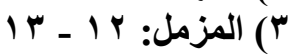


دردي الزيت وقال مجاهد: هو كالام والقيح ، وقال عكرمة: هو الشئ الأي انتهى حره ، وقال آخرون: هو كل شئ أذيب ، وقال الضحاك: ماء جهنم أسود، وهي سوداء وأهلها سود ، وهذه الأقوال ليس شيء منها ينفي الآخر؛ فإن المهل يجمع هذه الأوصاف الرذيلة كلها : فهو أسود منتن (') (ل)يظ حار )

وإنما اختص الوجوه \{ لكونها عند شربهم يقرب حرّها من وجوههم. وقيل : عبر بالوجوه عن جميع أبدانهم() على سبيل المجار لعلاقة الجزئية لإطلاق البعض وهو الوجوه \{ وإرادة الكل

أما الآية الثانية فتتحدث عما توعد الله به المكذبين من قيودٍ ثقيلةٍ ونارٍمستعرةٍ يُحرقون بها، وطعامِ كريهٍٍ لا يستساغ، لمرارته ،وكراهة طعمه وخبث ريحه .

فالثاعر كما نرى اقتبس من القرآن الكريم تثبيه شراب أهل الجحيم مضيفا إليه صورة بياتية : (يجرى السِّقاءُ)أقام بها الوزن، وأتم بها المعنى مبينا أثره على وجوههم ، مضيفا إليها أمعاءهم . كما اقتبس الشاعر وصف طعامهم من القرآن الكريم فهو طعام ذو غصة ينشب في الحلق فلا ياخل ولا يخرج ،كما قال ابن عباس (") . ويمضى الثاعر فى حديثه واصفا ما أعد للعصاة من عذاب وما ينتظرهم من ويلات :

1) 100/

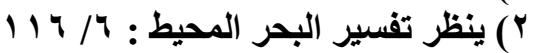

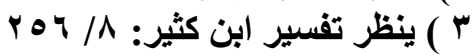




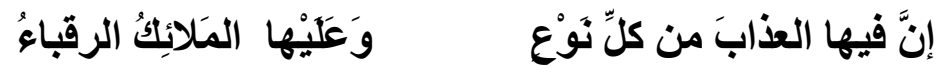

قد أطاعوا الرحمنَ في كُلِّ أمر وبأمر العزيز يَجْرى القضَاءُ

لا ظلايلّ بـها يُحِيْط القضاءُ دركاتُ سبعُ طباقُ عذابِّ

الموتَ وهيهاتَ يُسنتجابُ النداءُ

كلٌّ مَنْ في العَذابِ يَسنْتَصُْخ

حيثُ حلَّ الخلودُ زالَ القَّناءُ

أو عَدَابُّ مخهَّفُ أو رَجَاهُ

لا مماتُ بها يُهَهِنُِّ كَربْاً

بََّّلَ اللهُ غَيْرَها ما يَثَنَاءُ

كلما أنضجَ الحريقُ جُلوداً

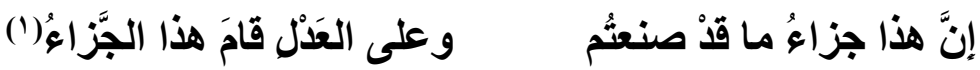

وهباءً يضيعُ كلُ تمن

ts


التبديل لضمير العظمة وتنكير (جلودا) وذكر علة التبديل: لِيَّاوقوا العَدَابَواستعارة الذوق للإحساس كل ذللك زيادة في ترهيبهُ وتجديد حزنهم ؛ إذ كُلَّمَا نضج جلدهم وتهري وتلاشى جيء بجلا آخر مكانه ليتجداد

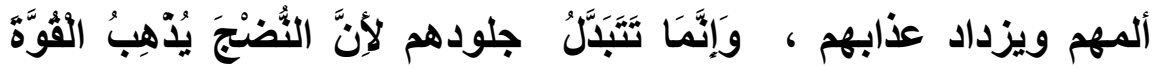

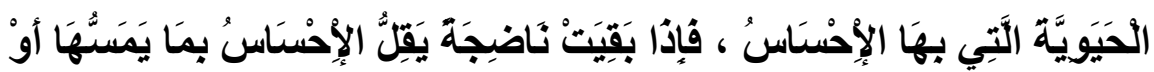

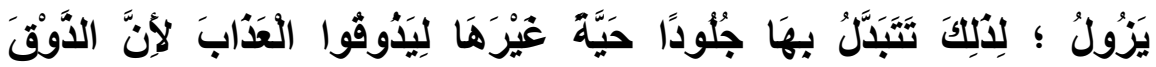

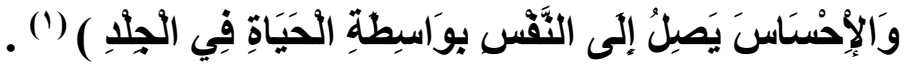
وقد كان القرن الكريم سباقا في الإشارة إلى هذه الحقيقة العلمية

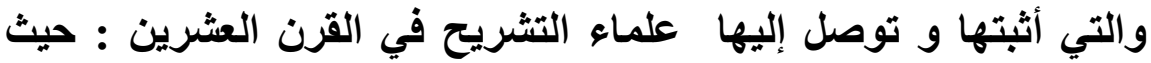
اثبتوا أن مراكز الإحساس بالألم وغيره إنما تتركز في طبقات الجلد الخارجية بشكل أساسي دون بقية الجسد ، و قد اقتبس الثاعر قوله :

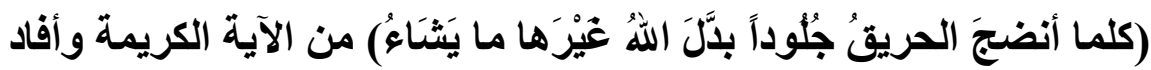

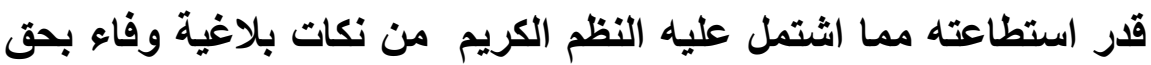

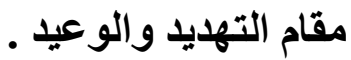

وكَمَا اقتبس الثاعر حلثيه عن الأشقياء وما أعد لهم من ألوان العذاب من القرآن الكريم ها هو ذا استنادا على القرآن الكريم واقتباسا منه

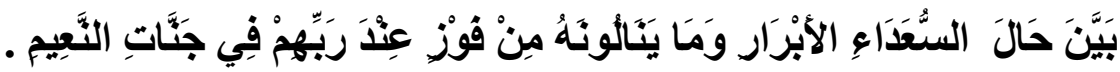

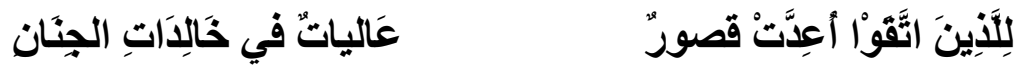

الاستغراق المستفاد من (كل) ينظر معجم حروف المعاني في القرآن الكريم محمد حسن

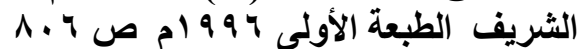
() تفسير المنار محمد رشيد بن علي رضا مطبعة المنار الطبعة الثانية : 10 ـ 17 
كاللآلَى ما بَيْنَ حُور حِنَان

من كَريمِ الياقوتِ والمرجان

من نُضَارِ ومن نَعِيْمِ الجُمَان حور عين من كاعباتٍ قِيَان

$$
\text { بشراب الأعناب والرمان }
$$

عَرُْْ مسكِ ونفحةُ الرَّيْحَان

وَجَنَاهَا أَيَّانَ تدعون دان ()
والقرَاديْسُ زيُبِّتَنْ بيدور

وبدار النعيم صُقتتْ بيوتهٌ

عُرَفْ تَحْتَ زهر ها المَاءُ يَجْزى

تَتَجِّلى على الأرائلكِ فيها

وَعَلَيْهنَّ طافَ ولَدَانُ خلادِ

فَى أبَارِيقَ مِنْ لْجَيْنِ شَذَاهِا

إنَّ فيها ما تَثْتُنَهِ كلُ نفس

فالثاعر يتحدث عما أعد لأهل الجنة من ألوان المتع و مظاهر النعيم

المقيم

من مجالس فاخرة ، و أنهار جارية ، وظلال وارفة ، وحور عِين ،

و كما نرى فقد استوحى الثـاعر أوصافه لنعيم أهل الجنة واقتبسها من القرآن الكريم قال الله تعالى :

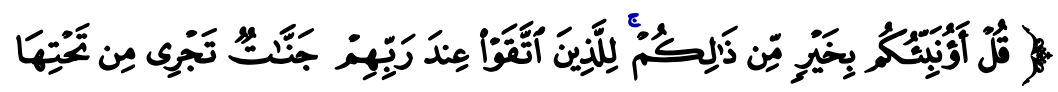

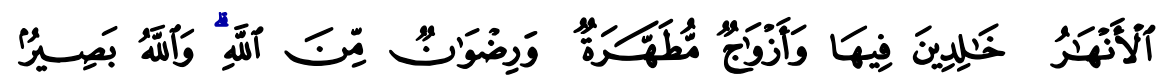

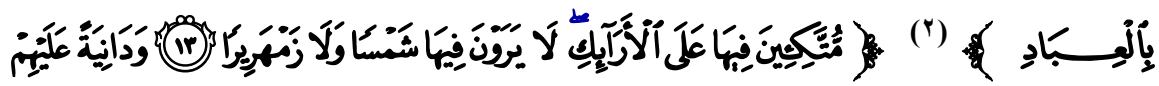

$$
\begin{aligned}
& \text { ( ) الديوان : } \\
& \text { r) آل عمران : }
\end{aligned}
$$




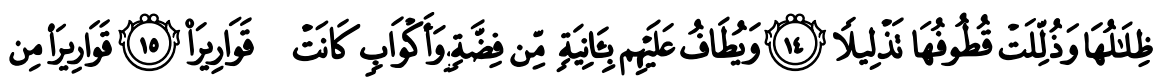

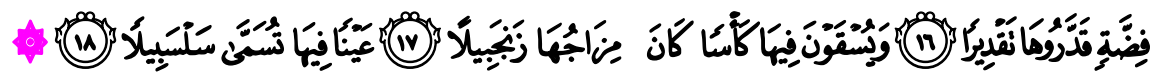

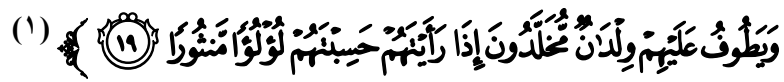

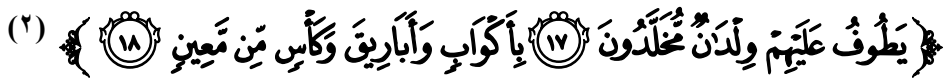

(")

(")

فالآيات الكريمة وغيرها الكثير قد صور ت ما أعده الله ـتعالى -

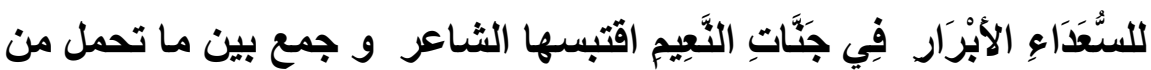
مظاهر الترف وألوان المتع ، وصاغها صياغة شعرية متأثرا بلغة القرآن

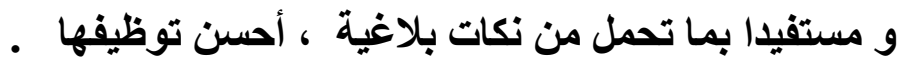

وقبيل ختام نونيته الكبرى تطرق الثاعر للحديث عن يوم الفصل حيث يجازى كل بما قدم مسترسلا في وصف نعيم أهل الجنة فيقول :

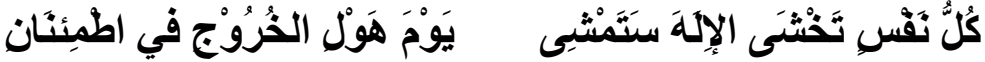

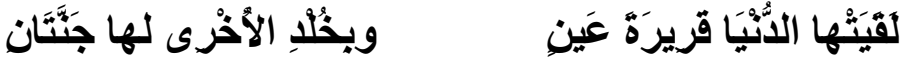

$$
\begin{aligned}
& \text { ( ) الإنسان: } 19 \text { - } 19
\end{aligned}
$$

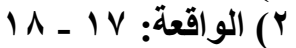

$$
\begin{aligned}
& \text { ץ) فصلت : الرافة: }
\end{aligned}
$$

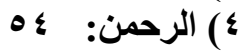




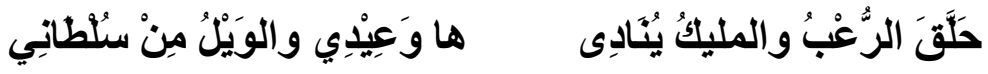

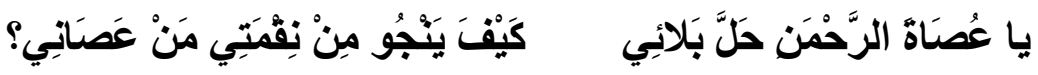

ما جُنُودُ الثََّّطان إلا عُواهُ

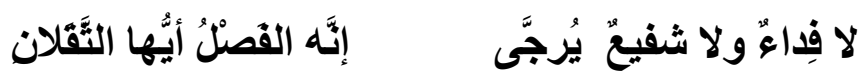

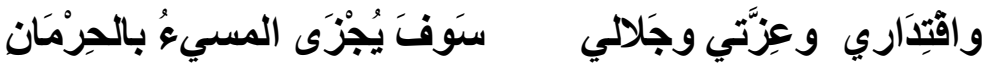

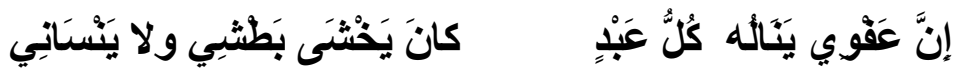

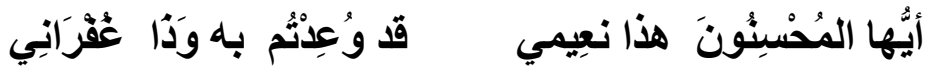

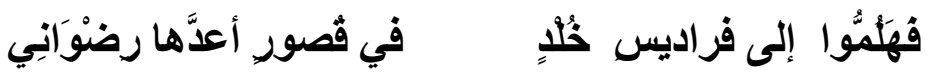

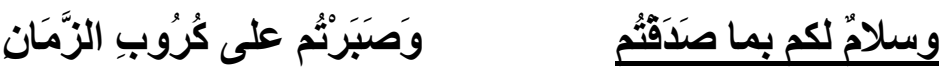

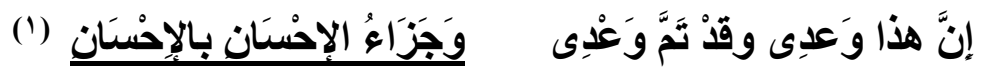

و الثاعر كما رأينا يختم حديثه عن ألوان النعيم المعد للمتقين في

دار الكرامة بإلقاء التحية والإكرام : (وسلامٌ لكم بما صَدَقَتُمْ وَصَبَرْنُم على كُرُوب الزَّمَان ) وهو في ذلتك مقتبس من القرآن الكريم تحية الملائكة

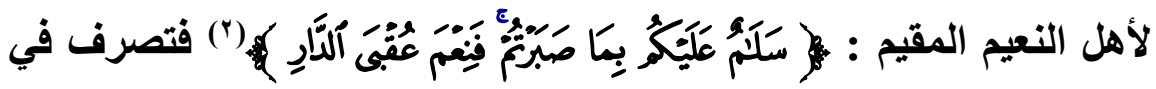
الاقتباس بتغيير حرف الجر ، وزيادة الفعل (صدقتم ) 


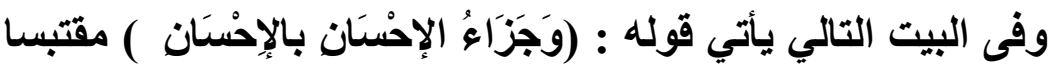

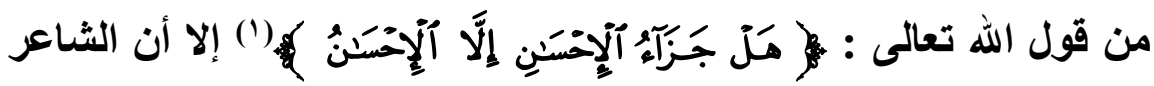
حول صيغة الاستفهام وهو استفهام مجارى يراد به النفي إلى التقرير :

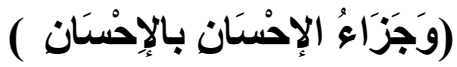

$* * * * * * * * * * *$ 


\section{الخاثمل وأهم النتائج}

فهذه دراسة بلاغية متأنية ، و تحليل دقيق لإحدى الظواهر الأسلوبية المهمة التي عبرت عن ثُقافة الثاعر إسماعيل صبري أبو أميمة ، و إلمامِهـ بدقائق اللغة العربية وآدابها ، وتمكنه من تراثهه الايني والأدبي ، و تأثره بكثير من الصياغات القرآنيـة ، حاولت مـن خلالها الكثـف عن جمـال الاقتباس ، و بلاغته، و علاقته بالسياق ، مبينا كيف يندمج بيانُ القرآن في

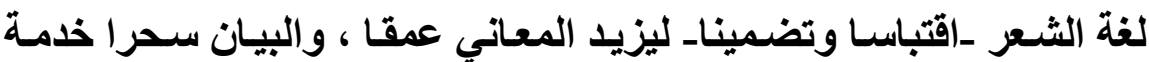
للسياق و وفاء بالغرض الذي جيء من أجله ، مؤكدا على أن الاقتباس لون بلاغي دقيق المسلك ينطوي علي كثير من الإشـارات الفنية الاقيقة ، تتعانق مع اللطائف البلاغية الأخرى لتمنح النص قوة وعمقا ، وروحانية وقداسة ، ينعكس تأثيرها في إثراء الذوق الأدبي والبلاغي ، لا سميا وأن الثاعر كان موفقاً لارجة كبيرة في صياغته الثعرية، ومتمكنا من اقتناصه للكثير من الآيـات القرآنيـة ، مستثمرا إمكاناتها الدلاليـة كاثـفا عن ملكته فئه البيانيـة، مفصـحا عن براعتهـه في حسن اختيـار النص القرآنـي المناسب لغرضه ، مظهرا مهارته في إحكام الصلة بين كلامهه والكلام الذي أخذه،

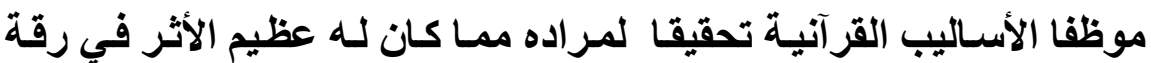

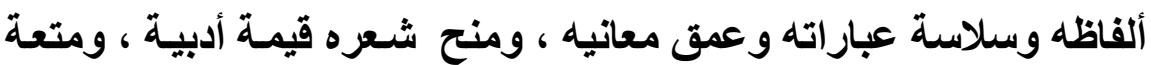

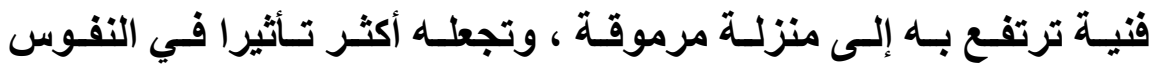


وختامـا فالكمـال لله وحده ، واللهَ اســأل أن يجعل هذا العمـل خالصـاً

لوجهه الكريم ، ربنا لا تأخذنا إن نسينا أو أخطانا ، والحمد الله أولاو آخرا

666

ـ 


\section{أهمر المصسادر والمراجع}

\section{القرآن الكعريم}

ا - الإتقـان في علـوم القرآن جـلال الدين عبد الرحمن السيوطي

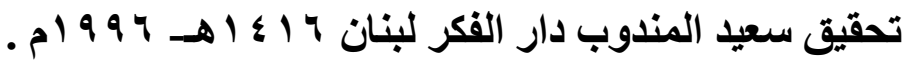

r - إعجاز القرآن محمد خلف الله أحمد ، محمد زغلول سـلام دار

العارف ، الطبعة الثالثة .

r- الإعجاز اللغوي والبياني في القرآن الكريم جمع وإعداد علي بن نايف الشحود ـ اهن

ع- الاقتباس أنواعه وأحكامه دراسة شرعية بلاغيـة في الاقتبـاس من القرآن والحديث عبد المحسن عبد العزيز العسكر مكتبة دار المنهاج الرياض الطبعة الأولى .

0ـ الاقتباس والتضمين في شعر ابن درَّاج القسطلى بحث تكميلي لنيل درجة الماجستير في البلاغة والنقد هنـاء فلحان القرشي لئي

$$
\text { جامعة أم القزى }
$$

7- الاقتبـاس من القرآن الكريم في الشـعر العربـي عبد الهـادي الفكيكى منشـورات دار النمير سـوريا دمشّق الطبعة الأولى 
V- الإيضـاح في علوم البلاغة المعاني والبيان والبديع الخطيب القزويني دار الكتب العلمية بيروت لبنان .

1- البحر المديد أحمد بن عجيبة الحسني الإدريسي دار الكتب

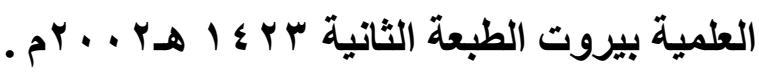

9- البرهان في علوم القرآن محمد بن بهادر بن عبد الله الزركثي

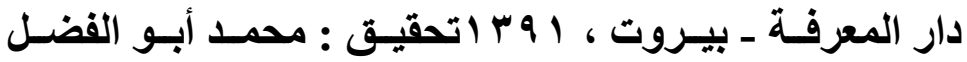
- إبراهيم

• 1 - بصـائر ذوى التمييز في لطـائف الكتـاب العزيـز الفيروزابـادى

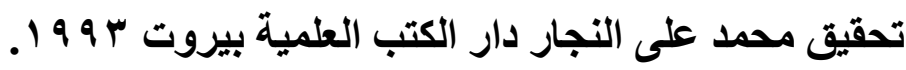

11 - بغية الإيضاح لتلخيص المفتاح في علوم البلاغة عبد المتعال

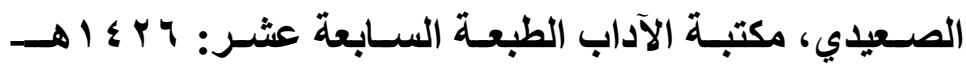

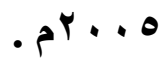

r ا - البلاغة العالية علم المعاني عبد المتعـال الصعيدي قدم لـه د عبد القادر حسين مكتبة الآداب الطبعة الثانية .

با 1 - البلاغة العربية أسسها وعلومها وفنونها عبد الرحمن حبنكة

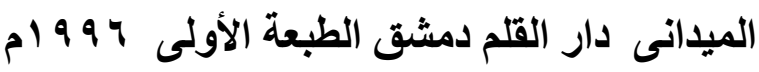

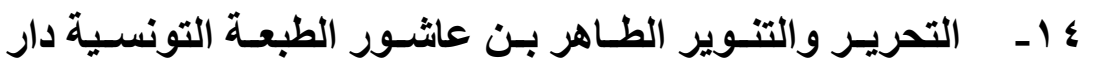

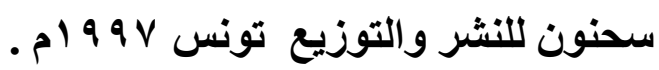


هـ - التسهيل لعلوم التنزيل لابن جزي الكلبي محمد سـالم هاثم دار الكتب العلمية بيروت لبنان الطبعة الأولى ـ الكئ لئل

17 ا - تفسير أبي السعود إرشاد العقل السليم إلى مزايا القرآن الكريم محمد بن محمد العمادي أبو السعود دار إحياء التراث العربي -

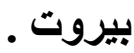

IV - تفسير البحر المحيط لأبسي حيـان دار الكتب العلميـة لبنـان

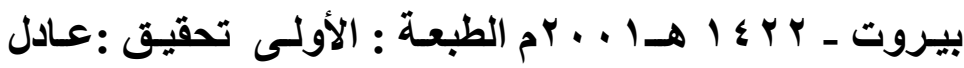
أحمد عبد الموجود وعلي محمد معوض .

11 اـ تفسير البغوي معـالم التنزيل أبو محمد الحسين بن مسعود البغوي محمد عبد الله النمر ـ عثمان جمعة ضميرية ـ سليمان

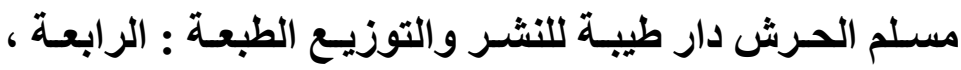

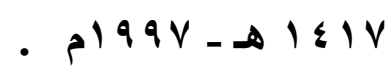
19- تقسير حقي موقع التفاسير .

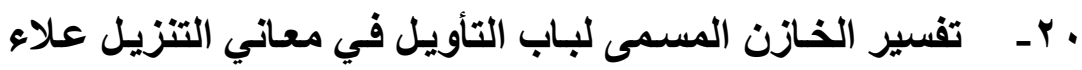
الدين علي بن محمد بن إبراهيم البغدادي الثـهير بالخـازن دار

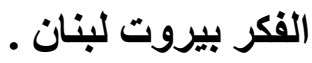

آ- تفسير السعدي تيسير الكريم الرحمن في تفسير كلام المنـان عبد الرحمن بن ناصر بن السعدي مؤسسة الرسـالة الطبعة : الأولى 


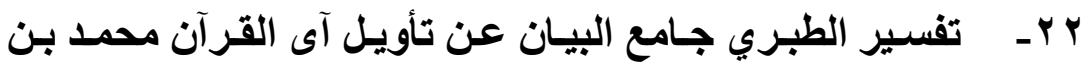

$$
\text { جرير الطبري دار الفكر بيروت . }
$$

ب r- تقفسير القرآن العظيم أبو القداء إسماعيل بن عمر بن كثير

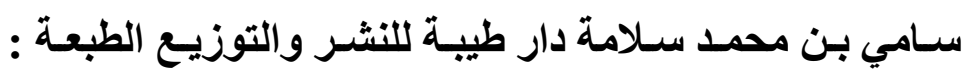

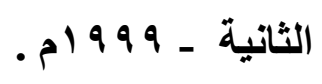

§ ؟- تفسير القرطبي الجامع لأحكام القرآن محمد بن أحمد القرطبي

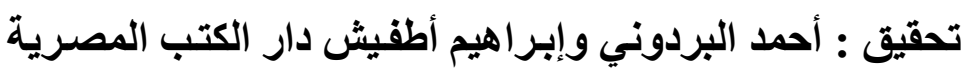

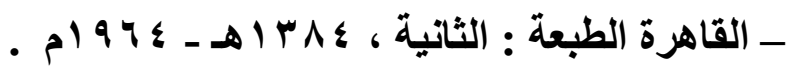

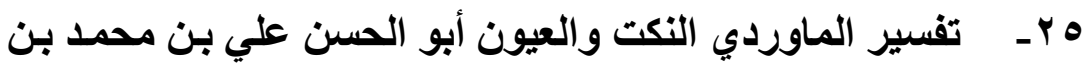
حبيب المساوردي البصـري دار الكتب العلميـة بيزروت لبنـان

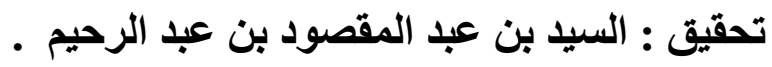

צ r- تفسير المنار محمد رشيد بن علي رضـا مطبعة المنـار الطبعة

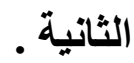

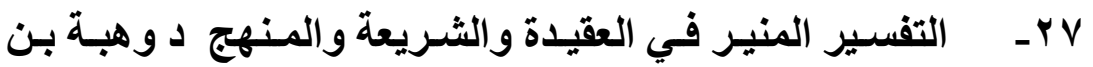
مصطفى الزحيلي دار الفكر المعاصر دمشق الطبعة الثانيـة ،

$$
\rightarrow 1 \varepsilon 11
$$

1 ץ- التفسير الوسيط محمد سيد طنطاوي موقع التفاسير . 
9 ؟ - التوقيف على مهمـات التعاريف محمد عبد الرعوف المنـاوي دار الفكر المعاصر ، دار الفكر بيروت ، دمثق الطبعة الأولى ، . إ ا تحقيق : د. محمد رضوان الداية.

• • - خصائص التراكيب دارسة تحليلية لمسائل علم المعاني د محمد

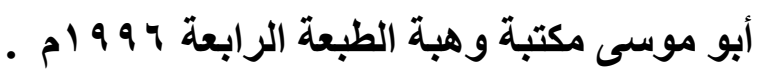

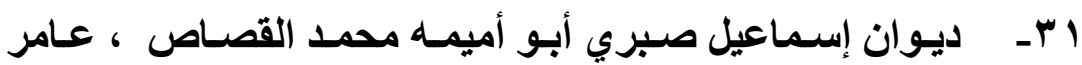

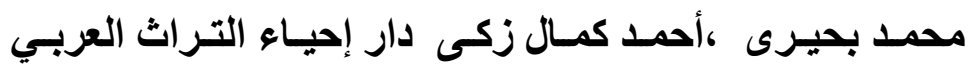

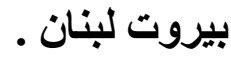

r r - روح المعاني في تفسير القرآن العظيم والسبع المثاني محمود الألوسي أبو الفضل دار إحياء التراث العربي - بيروت .

بr- هرة التفاسير الإمام محمد أبو زهرة : دار الفكر العربي . ع ז- شروح التلخيص ، دار السرور ، بيروت ، لبنان .

هـ- صحيح البخاري الجـامع المسند الصحيح المختصر من أمور

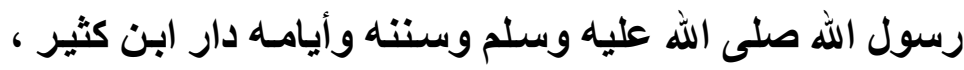

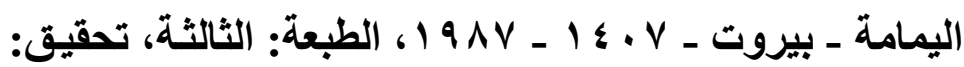
د مصطفى ديب البغا

آبـ صفوة التفاسير محمد علي الصابوني دار القرآن الكريم بيروت

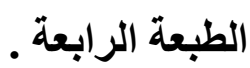




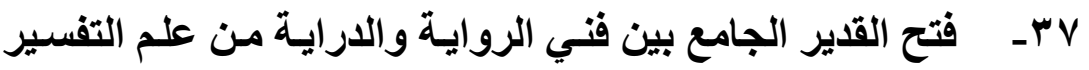
محمد بن علي بن محمد الشوكاني دار الفكر - بيروت .

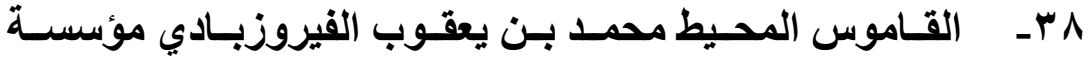
الرسالة بيروت

q بـ الكشاف عن حقائق التنزيل وعيون الأقاويل في وجوه التأويل الزمخشـري دار إحيـاء التـراث العربـي بيـروت عبــ الـرزاق

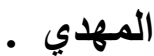

• ع - الكليات معجم في المصطلحات والفروق اللغويـة ، أبو البقاء أيوب بن موسى الحسيني الكفوي تحقيق: عدنان درويش محمـــ المصـري مؤسســة الرســالة بيـروت الطبعـة الثانيـة

$$
\text { - م) } 991 \text { ه } 1 \leq 19
$$

اء ـ كنوز الإعجاز العلمي في القرآن الكريم عبد الدائم الكحيل . Y ₹ - لسان العرب ابن منظور دار صادر بيروت الطبعة الأولى . rـ - المحيط في اللغة الصاحب بن عباد عالم الكتب - بيروت / لبنـان

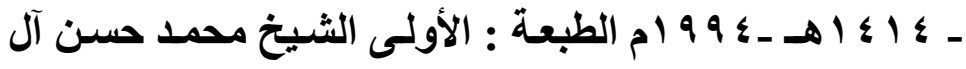

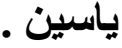

ع ــ - مختار الصحاح محمد بن أبي بكر بن عبد القادر الرازي مكتبة

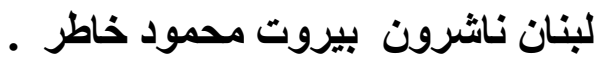


هـ ـ المصباح المنيـر أحمد بـن محمــ بـن علـي الفيومي المقري دراسة و تحقيق يوسف الثيخ محمد المكتبة العصرية .

צ ؛ - معجم حروف المعاني في القرآن الكريم محمد حسن الشريف

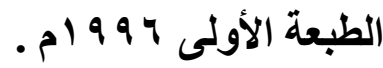

\& V

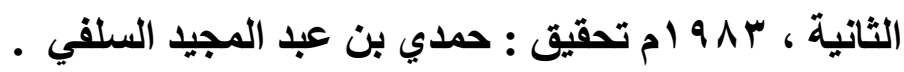

^ـ - مفاتيح الغيب فخر الدين الرازي دار الفكر للطباعة والنشر

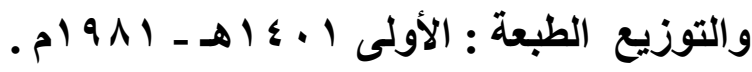

ج ـ - نظم الدرر نظم الدرر في تناسب الآيـات والسور برهـان الدين

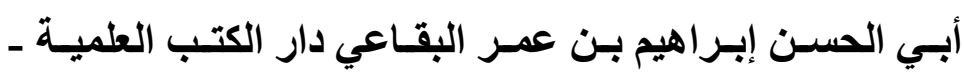

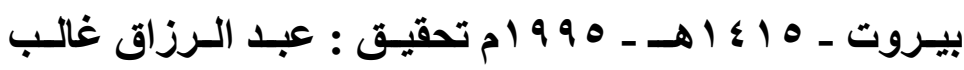
المهدي

• • - النكت في إعجاز القرآن لأبى الحسن على بن عيسى الرمـاني

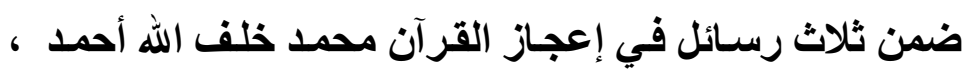
محمد زغلول سلام دار العارف ، الطبعة الثالثة . 